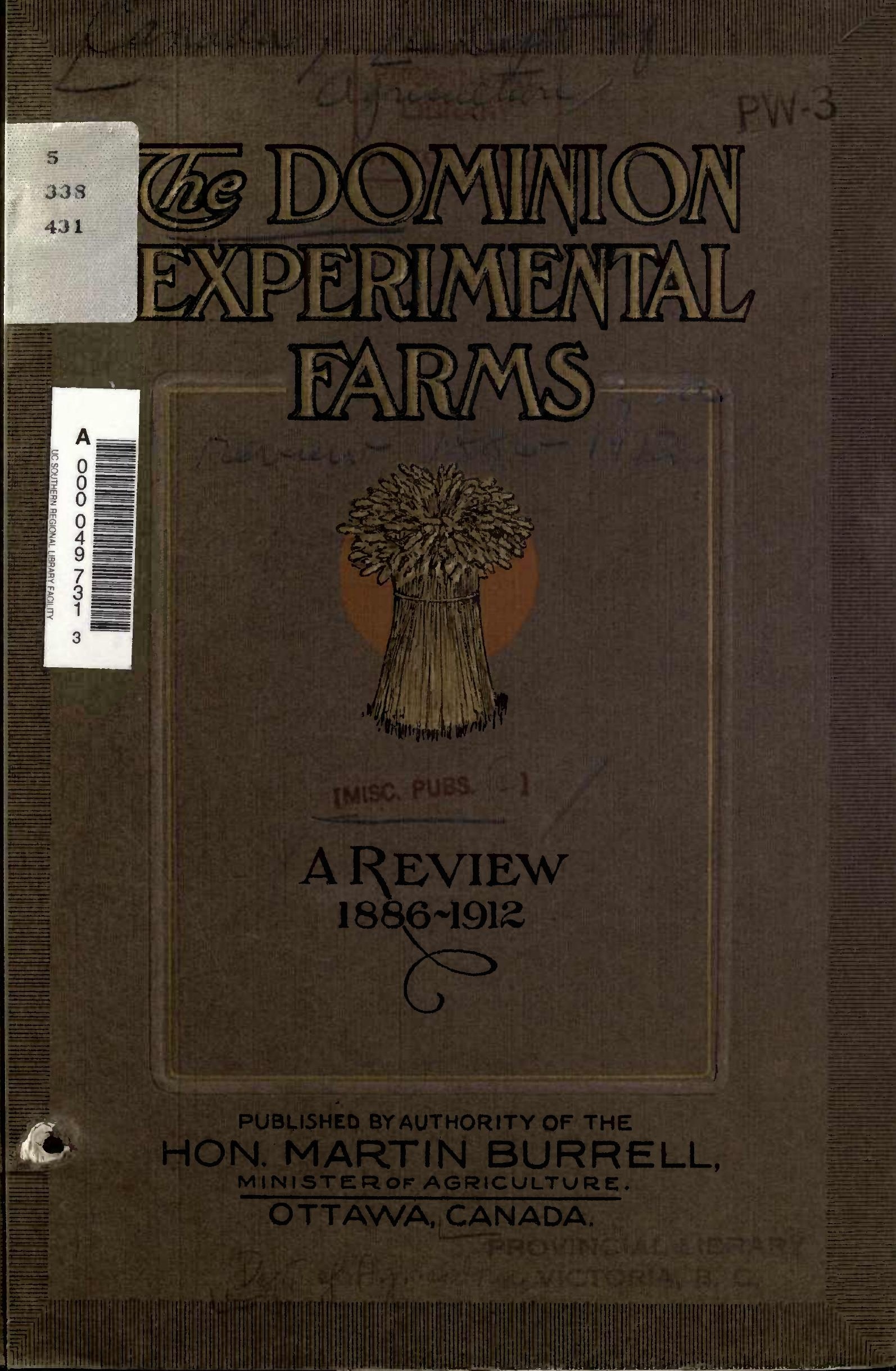




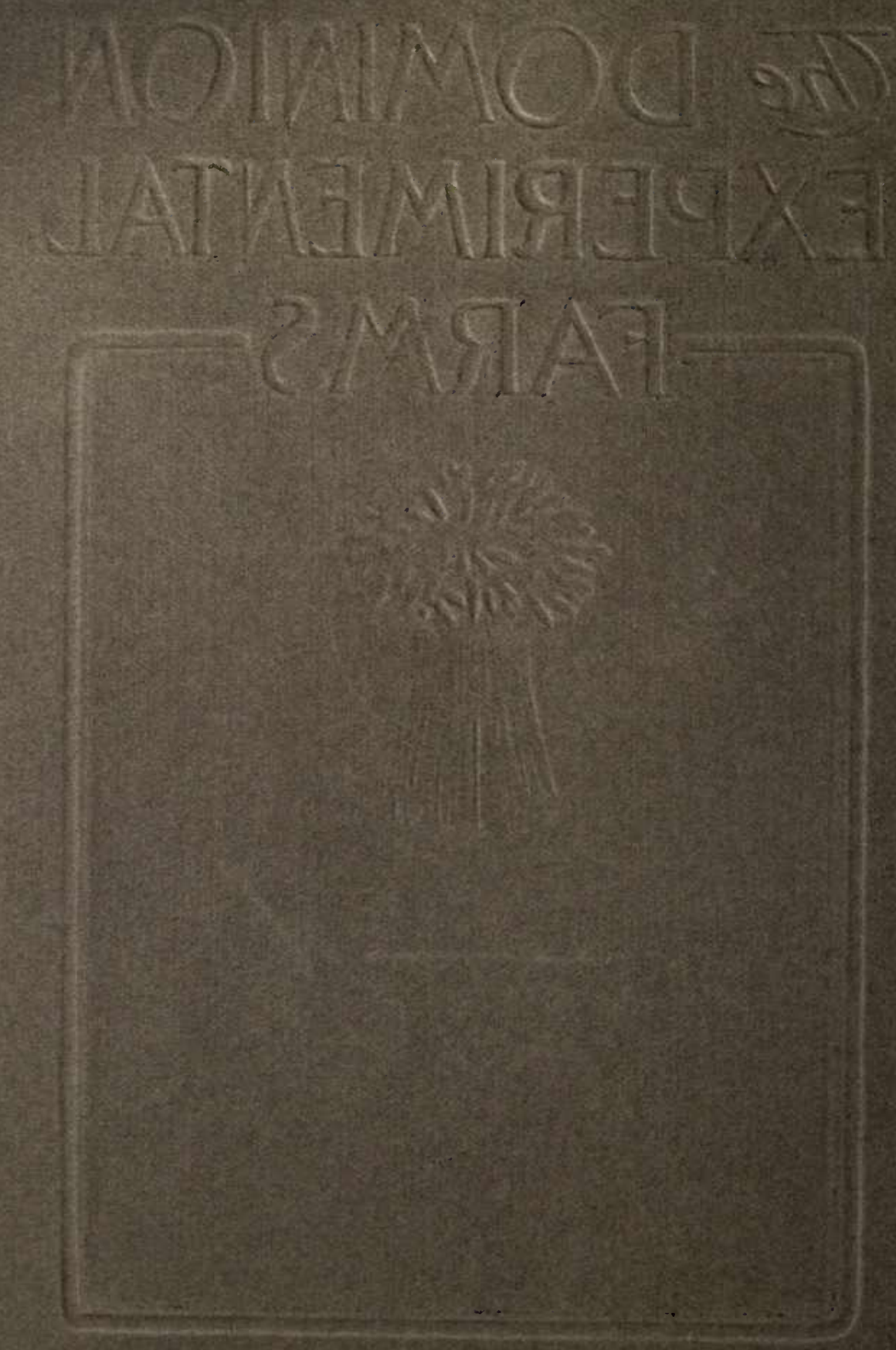





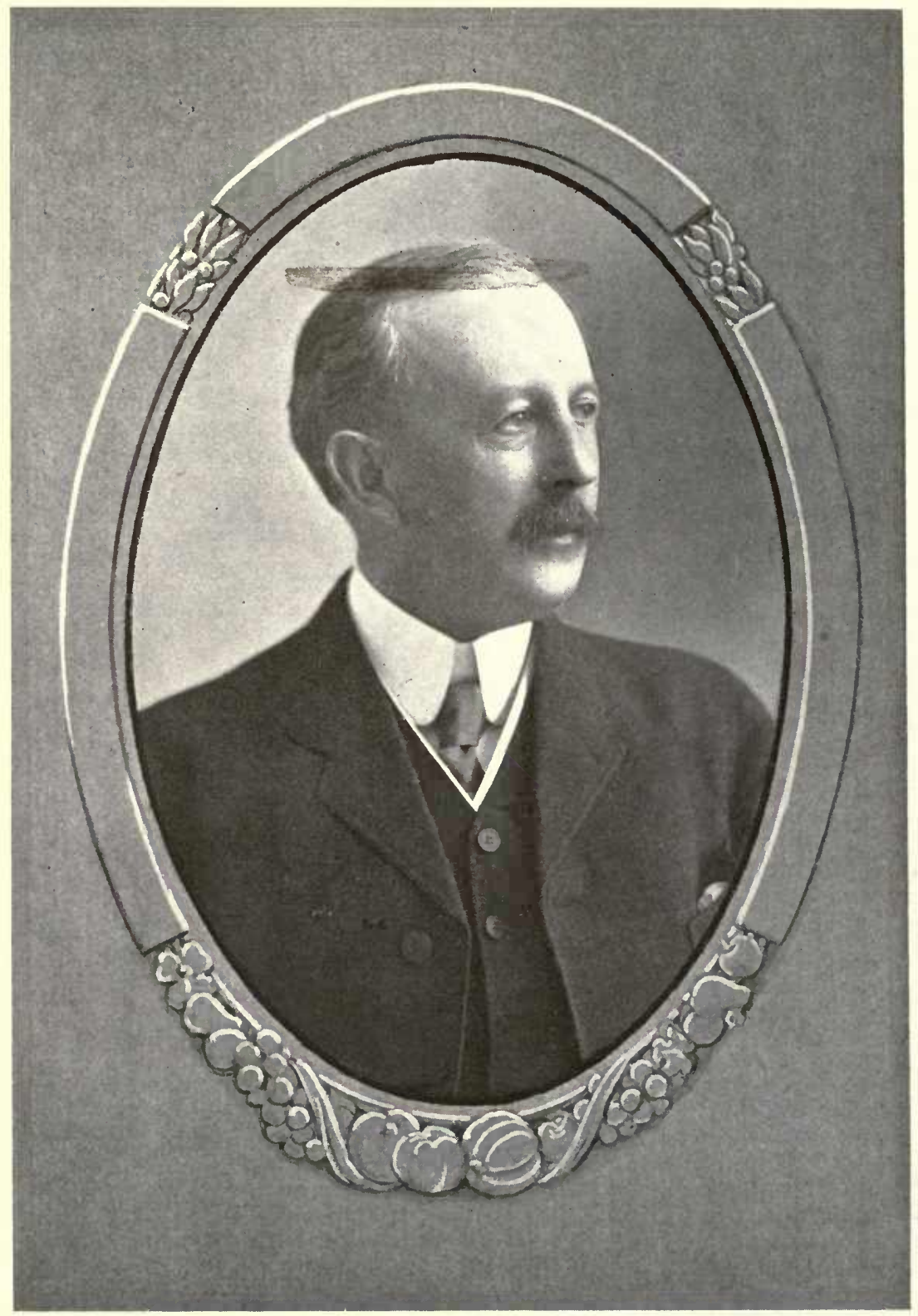

The Honourable Martin Burrelu, Minister of Agriculture.

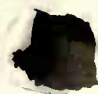


DOMINION OF CANADA

DEPARTMENT OF AGRICULTURE

\title{
A REVIEW OF THE WORK
}

\author{
OF THE
}

\section{EXPERIMENTAL FARMS}

BY

J. B. SPENCER, B.S.A.

Published by Direction of the Honourable Martin Burrell, Minister of Agriculture. 



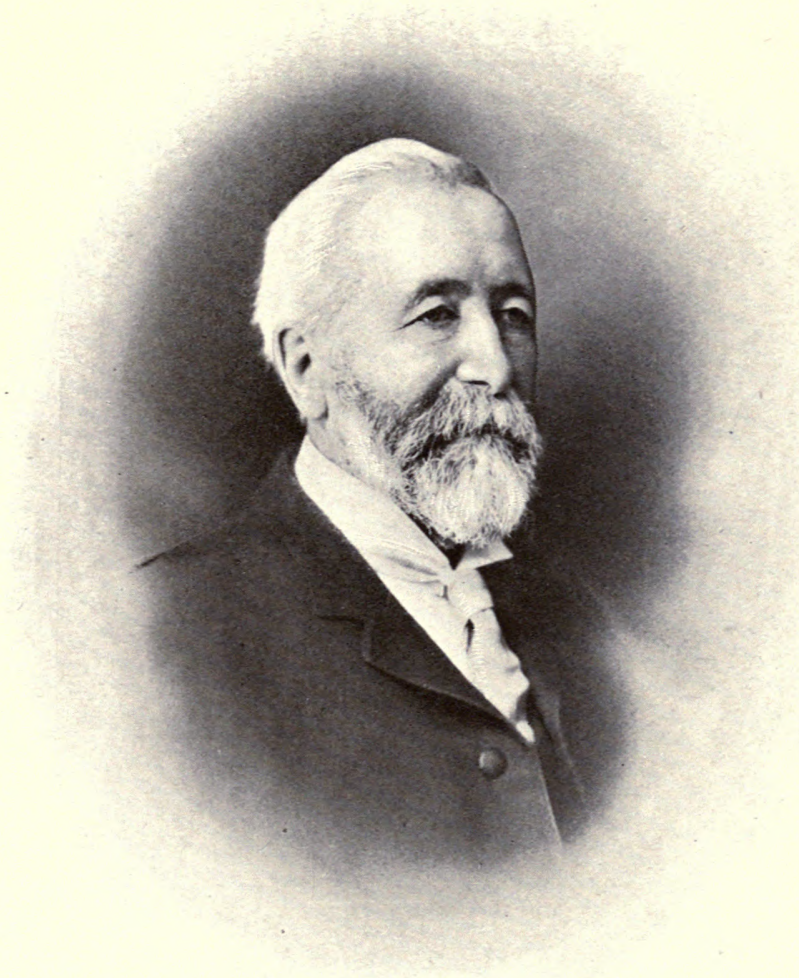

WM. Saunders, C.M.G., LL.D., F.R.S.C., F.L.S., for twenty-five years Director of Experimental Farms. 

Ottawa, November I, I9I2.

To the Honourable,

The Minister of Agriculture.

Sir:-

I have the honour to submit, for your approval, the accompanying review of the work of the Dominion Experimental Farms.

This presents in abridged form the principal accomplishments of the Experimental Farms during the quarter of a century in which Dr. William Saunders was the Director.

In its preparation reports and bulletins have been carefully gone through, the Director and the heads of Divisions have been freely consulted and no pains have been spared to search out from among the great mass of work accomplished the more outstanding results achieved.

This review, which has been prepared by Mr. J. B. Spencer, B. S. A., Editor of the Publications Branch, brings out in clear relief many lessons that will be helpful to the busy agriculturist who for want of time finds it impossible to thoroughly study the more exhaustive bulletins and reports issued by the Experimental Farms.

During the past year many new developments in the Farms system have taken place. These are described at greater or less length. It is hoped that this review will enable the rank and file of farmers in every province of the Dominion to still further profit by the work of the Experimental Farms which are equipped and carried on for their especial benefit.

I have the honour to be, sir,

Your obedient servant,

J. H. GRISDALE, Director. 


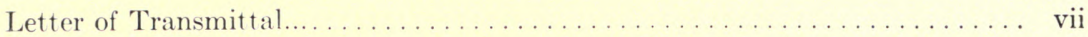

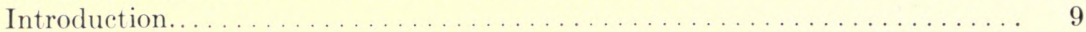

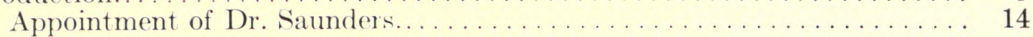

Experiments with Fertilizers. ......................... 17

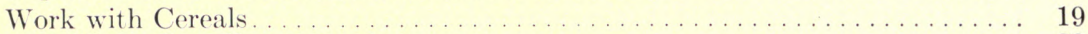

Wheat Breeding.................................. 20

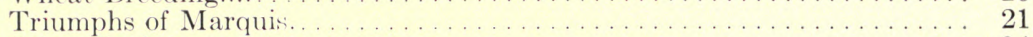

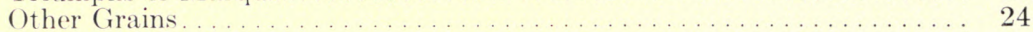

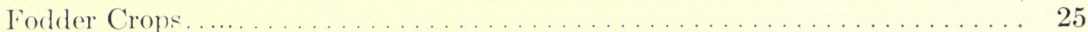

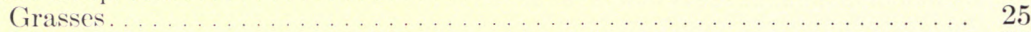

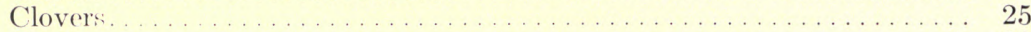

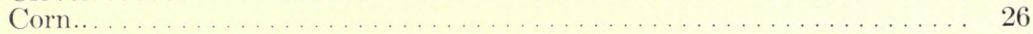

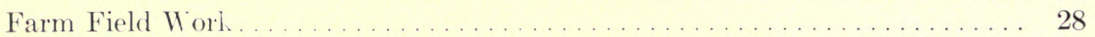

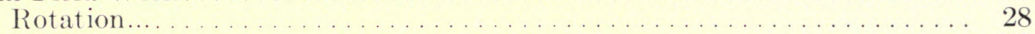

Manuring..................................... 30

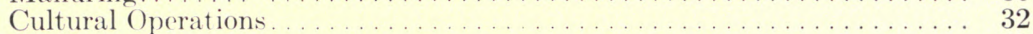

Seeding . . . . . . . . . . . . . . . . . . . 32

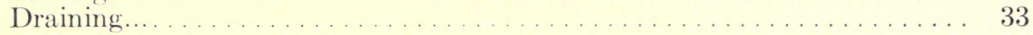

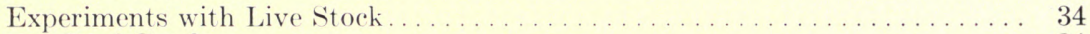

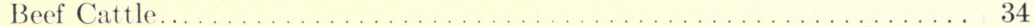

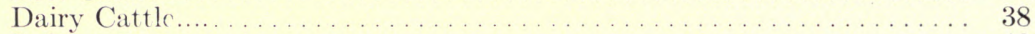

Swine................. 40

Feeding Working Horses. . . . . . . . . . . . . . . . . . . . . 43

Ventilation...................................... 44

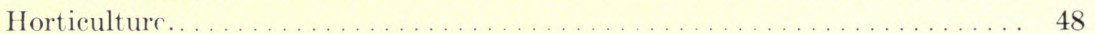

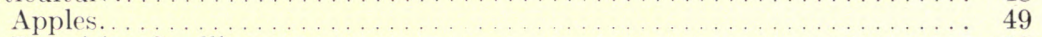

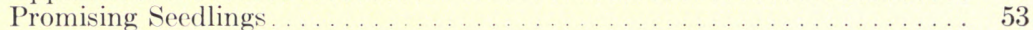

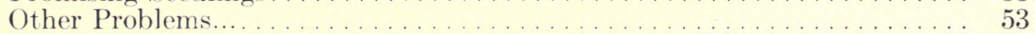

Other Fruits.

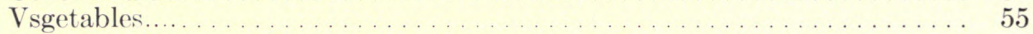

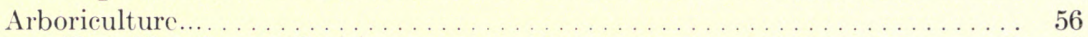

Tree Planting on Prairies............................ 56

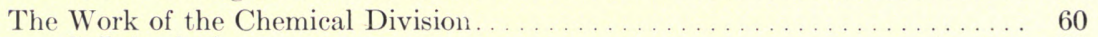

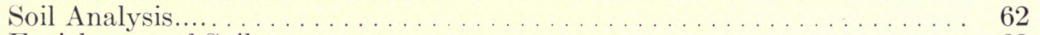

Enrichment of Soil $\ldots \ldots \ldots \ldots \ldots \ldots \ldots \ldots \ldots \ldots \ldots \ldots \ldots \ldots \ldots$

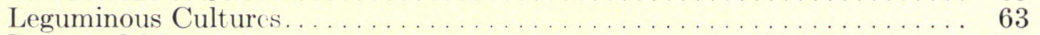

Barnyard Manure... . . . . . . . . . . . . . . . . . . . . . . . . . . . . 64

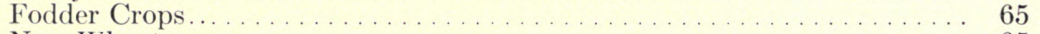

New Wheats........................... 65

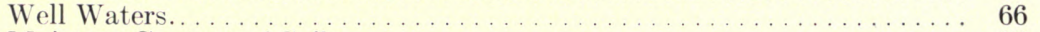

Moisture Content of Soils............ 66

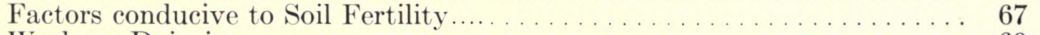

Work on Dairying........ . . . . . . . . . . . . . 69

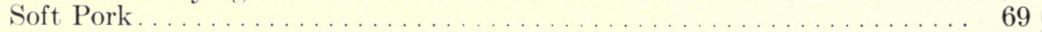

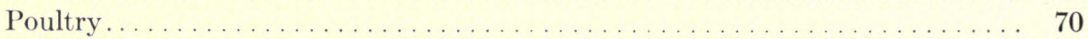

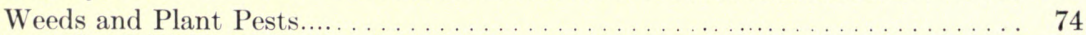

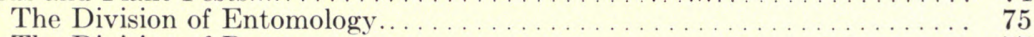

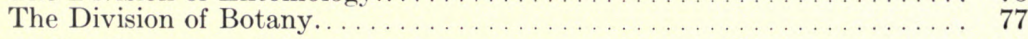

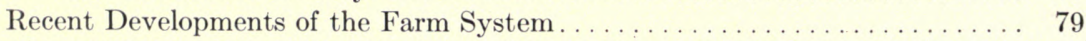

List of Past and Present Directors, Chief Officers of Divisions and Superintendents of Branch Farms and Stations.................... 81 


\title{
A REVIEW OF THE WORK OF THE DOMINION EXPERIMENTAL FARMS.
}

\author{
INTRODUCTION.
}

It is now over a quarter of a century since the Dominion Experimental Farms system was inaugurated under the Directorship of Dr. William Saunders who remained at the head of the system until his retirement a little more than a year ago. This period has been marked by an extraordinary development of Canadian agriculture.

In the early eighties, when it was decided by the Government that something should be done to improve the conditions of agriculure, the industry had reached a comparatively low ebb. In the older provinces, the land was commencing to show in a pronounced way the results of primitive methods of cultivation. In the newer provinces, just then opened up, the conditions of soil and climate called for very different methods from those to which the farmers in this and other countries had been accustomed. This condition, with the other already mentioned, demanded a widespread movement that would cope with the situation in all parts of the Dominion.

The advancement that has been made is fairly accurately represented in the production of the principal cereals and numbers of live stock in I89I compared with I9I2. These are shown in the following tables:-

$\begin{array}{ccc}\text { WHEAT } & \text { OATS } & \text { BARLEY } \\ \text { Bush. } & \text { Bush. } & \text { Bush. }\end{array}$

I $891 \ldots \ldots . \quad 4$ I I I $44,779 \ldots \ldots \quad 82,5$ I 5,4 I $5 \ldots \ldots \quad$ I 7, I 48, I 98

I9I $\ldots \ldots \ldots$ I $\ldots 9,236,000 \ldots \ldots$ 36I,733,000 . . . . 44,014,000

$\begin{array}{ccccc} & \text { HORSES } & \text { CATTLE } & \text { SHEEP } & \text { SWINE } \\ \text { I } 891 \ldots \ldots \ldots \ldots & \text { I }, 470,572 \ldots & 3,997,781 \ldots & 2,563,781 \ldots & 1,733,850 \\ \text { I } 912 \ldots \ldots \ldots \ldots & 2,336,800 \ldots & 6,983,700 \ldots & 2,360,600 \ldots & 2,656,400\end{array}$

These figures do not, however, reveal the backward methods under which farming was carried on in those days, and which were most in need of improvement.

In the older provinces, as on the Prairies at the present time, it was the rule to depend chiefly upon the sale of grain for revenue. 
Had this been grown in the light of the knowledge possessed by almost every tiller of the soil of the present day, conditions would not have reached so serious a state as to excite alarm. The more progressive farmers knew no better way to clean the land than by bare following. The yard manure was not considered fit to apply until it had rotted down to a black, mushy condition, and then it was not infrequently applied at an extraordinary rate per acre and this almost entirely to the hoed crop. In the light of the present day much time was wasted in ploughing deeply to the loss of much valuable fer-

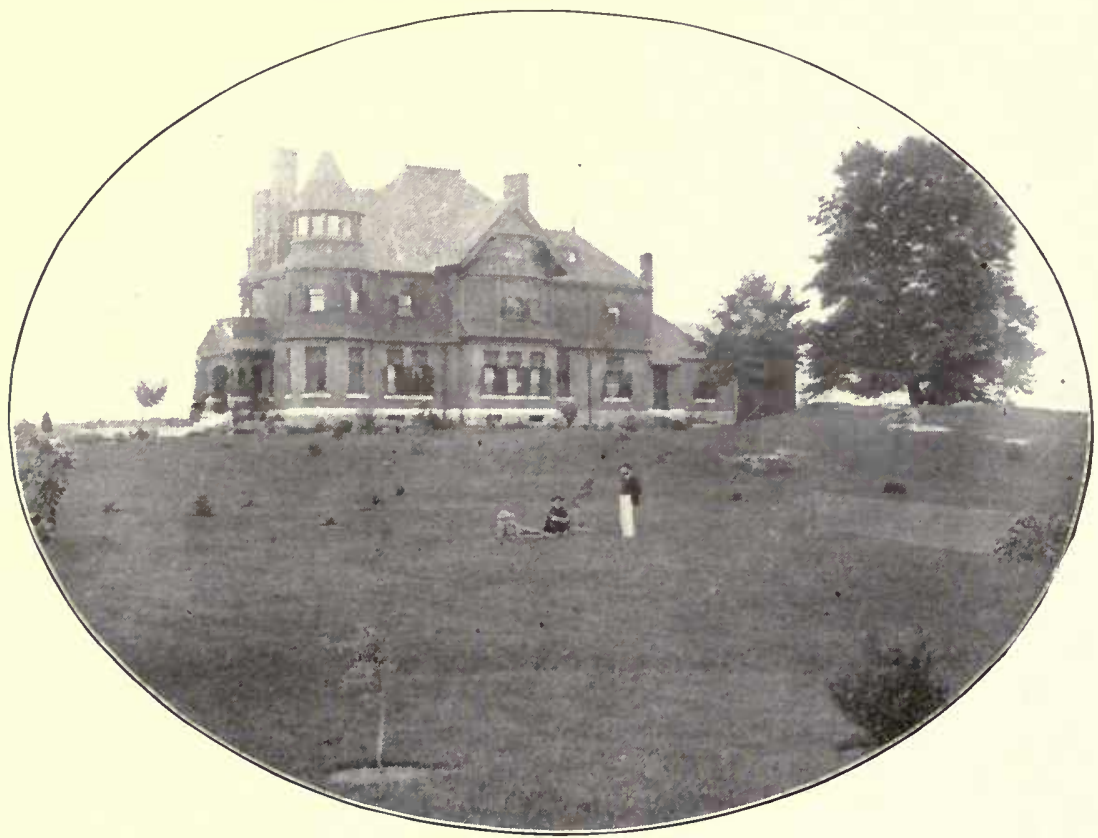

The Director's residenec from the north, 1891.

tility. The value of surface tillage to conserve moisture was not understood and in dry years the losses were enormous. The gospel of clover growing for the land's sake was not yet accepted by the rank and file who looked upon it as too valuable food to plow under. To speak of bacteria in the soil was to court ridicule and bring derision upon a "book farmer." Here and there a staunch Old-Countryman observed in a more or less intelligent way a system of crop rotation, but few even of these men understood, as most farmers do now, the true underlying principles of a successful system. Practically no one ploughed a clover sod in those days, but land was left in grass until the native sorts had driven the cultivated varieties from the field. To 
the average man, oats were white or black, wheat fall or spring, bald or bearded, and barley was only barley. Those who were careful to sow good seed selected their own or their neighbor's plumpest seed and put it once or possibly twice through the fanning mill. So little was known of new sorts that persons desiring something better were compelled to depend upon agents for information regarding cropping values and many a credulous man was seriously victimized before the days of Experimental Farms.

Many will remember the introduction of Eldorado wheat, a

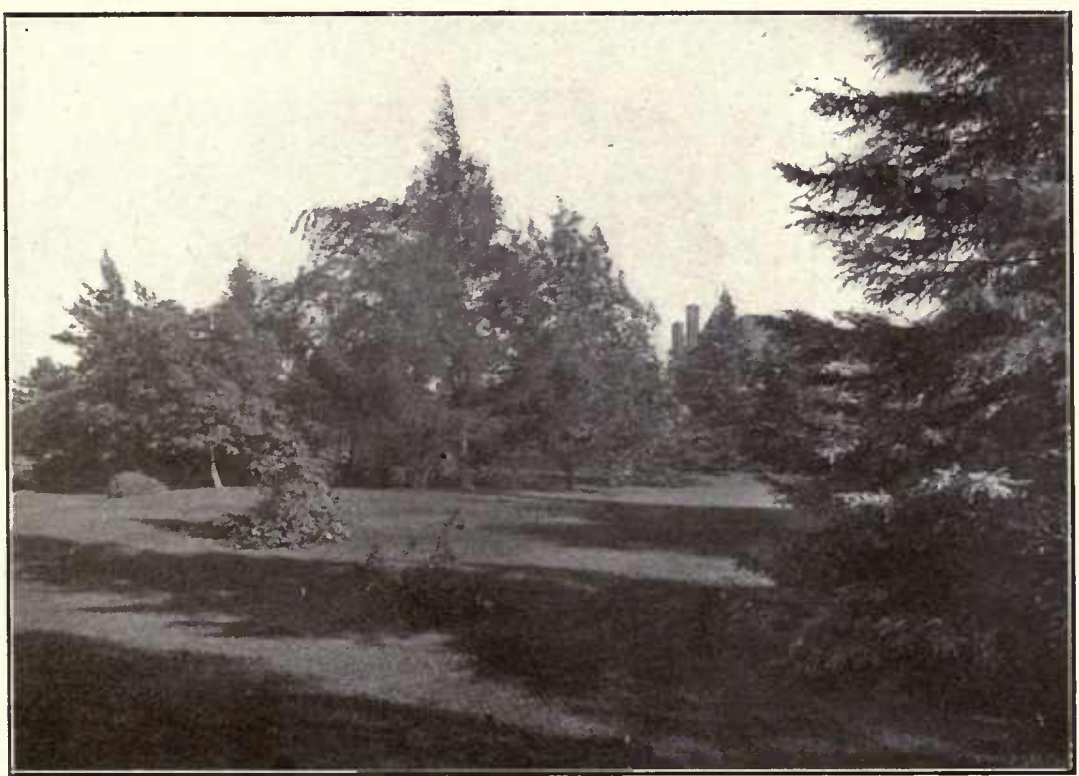

The Director's residence from the north in 1912 .

so-called Egyptian variety that on account of its thick, irregular head was claimed to produce extraordinary yields. In the county of Ontario, many fields were sown with seed that cost twelve dollars per bushel and few who saw the harvest will soon forget the miserable yield of inferior grain.

It cannot be gainsaid that for a comparatively long period Canada has occupied a foremost position in regard to the live stock industry. That is to say, we have had many excellent studs, herds and flocks and with these have justly won international fame. Through stock breeders, the entire agricultural industry has immensely benefited, but how many of them, to say nothing of the less 
thorough farmers before the lays of Experimental Farms, understood the true economy of early maturity. It is true, stables of excellent bullocks were sent out with each succeeding spring and left behind long prices, but no one shall ever know how expensively such beef was made. The average farmer took a keen pride in the weight and thickness of his year-old or more hogs. Ultimate size of animal and gross return not infrequently clouded the vision to actual profit.

Intil recent years, grave mistakes were made in the housing of stock. In the winter season, warmth was considered the chief

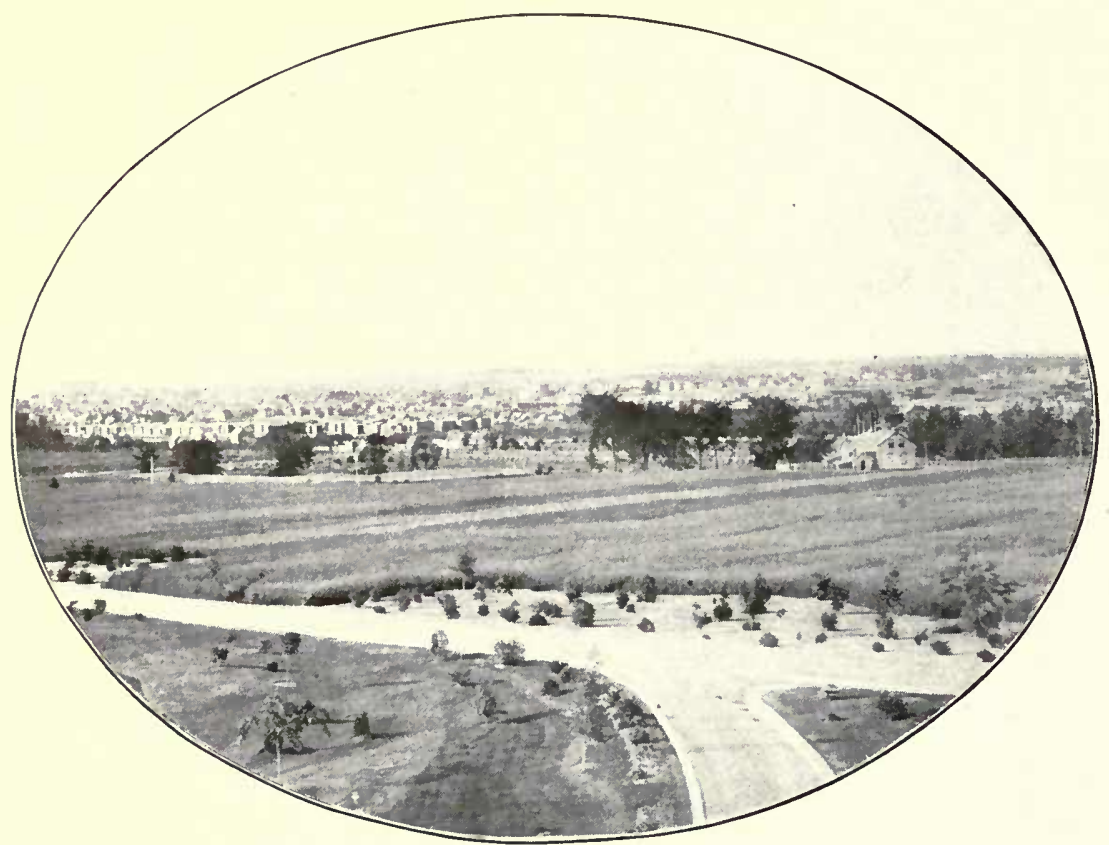

Looking towards the City of Ottawa from the Director's residenee in 1891.

factor, and as old stables were overhauled or replaced they were made as close as the circumstances of the builder would allow. The Experimental Farms have shed much light on the ventilation problems within the last few years.

The man who blindly retains and milks year after year the cows of his herd, without knowing whether or not they are paying for their feed, is recognized as being behind the times, but who thought of records and tests a quarter of a century ago? To milk cows in winter was not the rule but the exception, and it is no wonder agriculture got into a bad condition. 
The conditions that prevailed in connection with crop growing and stock raising were duplicated in the fruit growing and other agricultural industries and with as unsatisfactory results. People did the best they could, as they did not understand the better way that is now so evident everywhere. Agricultural education in Canada was in its infancy and the demand for it was even less strong. These, in a general way, were the conditions that prevailed in the older provinces of the Dominion in the early eighties. These were the days of the exodus of the young manhood of Canada to the United States.

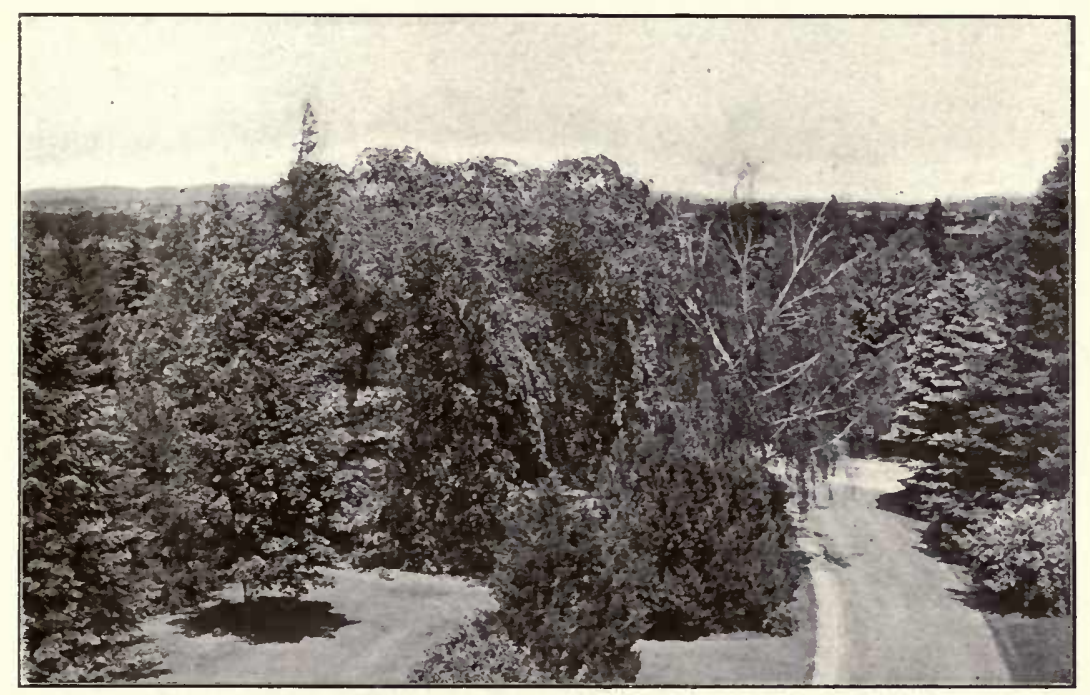

Looking towards the city in 1912.

Because it had been difficult to make a comfortable livelihood on the farm upon which they were raised, thousands of the sturdy sons of Canadian farmers moved over the international boundary and helped materially in the prosperity of the great Republic.

Agriculture in the Prairie Provinces had not yet become established. It was known that there existed a limited area of good farming land, but it was commencing to be realized that the methods of farming in the older provinces would not answer on the prairies. Summer drought, early fall frosts, an open, windswept prairie brought problems that had to be faced and solved to bring crop growing within the range of reasonable certainty. In these new provinces, the need of experimental work was apparent in a striking degree. It seemed as though the success of the country depended on it. It was not surprising, therefore, that the Government of the day was stirred up 
to look into the matter to see what could be done to improve the industry. Consequently, in $\mathbf{1} 884$, the House of Commons appointed a select committee to inquire as to the best means to adopt to encourage and develop the agricultural interests of Canada, in the prosperity of which all classes of the community were so deeply concerned. The report of the committee showed that agriculture in Canada at that time was in a lamentable and discouraging condition. It was shown that there was no lack of fertility in the soil and that climatic conditions were farourable for the production of good crops, but the prevailing depression, it was claimed, was due mainly to a widespread condition of ignorance among large portions of the farming community. This lack of information led to defective farming and the adoption of wasteful methods.

The committee recommended the establishment of experimental farms where experiments should be conducted with all sorts of farm crops and fruits to find out the best methods to adopt in order to bring more profitable results. It was further recommended that the information gained should be published from time to time and disseminated freely among the farmers of the Dominion.

During I 886 an Act was introduced and passed almost unanimously authorizing the Dominion Government to establish a Central Experimental Farm and four Branch Farms.

The work to be undertaken, as set forth in the Act under which these Farms were established, covered all the most important branches of agriculture, horticulture and arboriculture. Having before him the conditions of the industry and the work to be undertaken in its behalf, the Hon. John Carling, Minister of Agriculture, plainly saw the direction of the Farms must be in charge of a man trained in the sciences that underlie agriculture, a man possessing fine discernment and enthusiasm for the work. "There were plenty of strong, honourable men who were good farmers as understood in those days, but there was needed a man ahead of the time, who, by his work, would be likely to lead the people out from old fashioned methods to the better way that has now come to be so generally followed throughout the length and breadth of the Dominion.

APPOINTMENT OF DR. SAUNDERS.

In October, I886, the Minister chose for Director Mr. William Saunders, then a chemist, fruit grower and general farmer at London, Ontario. He had identified himself prominently with the sciences of horticulture, botany and entomology, and by his accom- 
plishments had received recognition abroad as well as at home by his appointment as Fellow of the Linnaean Society of London, England, corresponding member of the Royal Botanical Society of London, Fellow of the Entomological Society of London, a Director of the Fruit Growers' Association of Ontario, and an Honourary Member of the Highland and Agricultural Society of Scotland. He was the recipient of many other honours and distinctions. In 1905, by the gracious pleasure of His Majesty, the late King Edward, Dr. Saunders

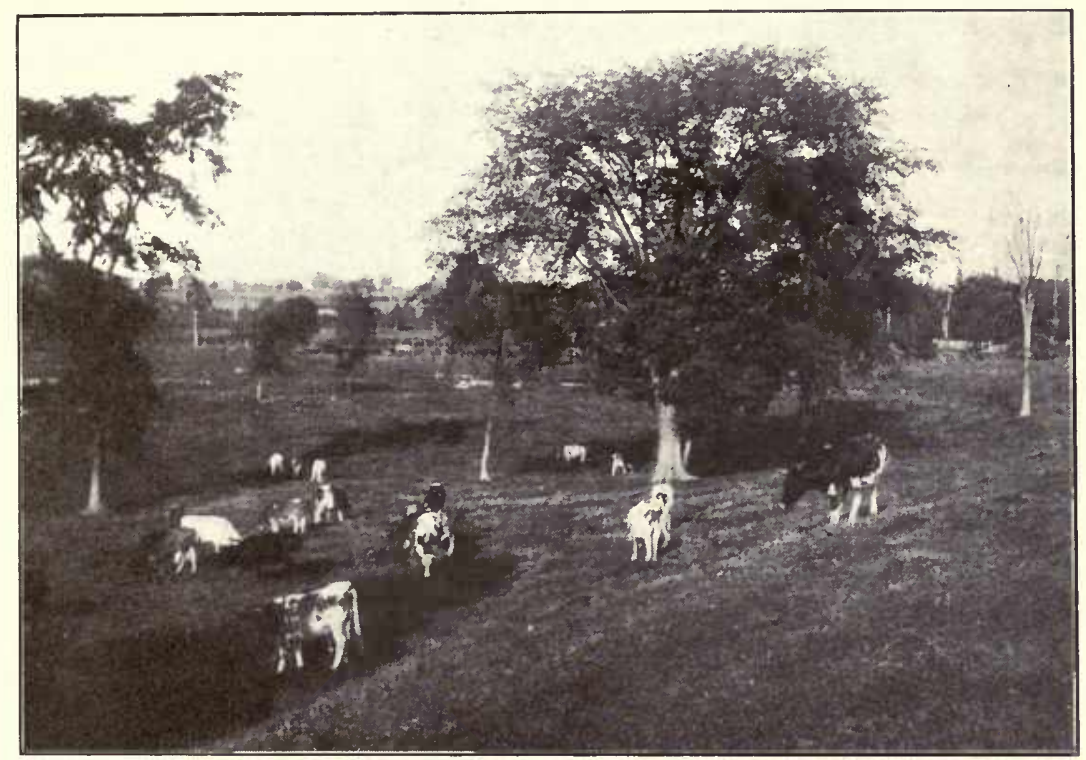

Dairy heifers at pasture on the Central Farm.

was appointed to be a Companion of the Most Distinguished Order of Saint Michael and Saint George.

During the two years following his appointment, Dr. Saunders made a close study of experimental farm work in other countries, and studiously considered the most suitable locations for the Farm sites. He was also entrusted with the selection of officers and in 1888 , the land for the several Farms was secured, the necessary officers appointed, most of the buildings erected and the Farms put into practical operation. The Central Farm was located at Ottawa, and Branch Farms at Nappan, N.S., Brandon, Man., Indian Head, Northwest Territories, and Agassiz, B. C. In choosing these sites, the purpose in view was to have them so located as to be fairly representative of the largest farming areas in the provinces they were to serve, while in the management of the work such experiments as 
would be most likely to be beneficial to the greatest number in each case were among the first to engage the attention of the officers in charge.

A strong factor in the success of Dr. Saunders' work has been his judgment in the selection of officers. During his almost entire career as Director, he had associated with him at the Central Farm, the late Dr. James Fletcher, as Botanist and Entomologist; Prof. Frank T. Shutt, as Chemist, Mr. A. G. Gilbert as Poultry Manager: Mr. Angus McKay at Indian Head, Mr. Thos. A. Sharpe at Agassiz, B. C., and until seven years ago Mr. S. A. Bedford as Superintendant at Brandon. By their earnest work on the respective Farms in solving, by the guidance of the Director, many of the problems of agriculture, and by proclaiming from lecture platforms throughout the country the lessons learned in their work, they have elevated the industry in a degree that would be difficult to estimate.

The Experimental Farms are bureaus of information to which farmers in all parts of the Dominion apply for advice and direction in times of difficulty, when confronted with problems which they are unable to solve. In 1889 , the year after the Farms had become fairly established, the total number of letters received was about 8.000: for the year ending March 3I, I9I2, the number received was about 124, coo. In 1889 , comparatively few reports and bulletins were issued, whereas in the year ending March 3I, I9I2, no less than 200,000 were sent out. There is thus a constant flow of information going out to Canadian farmers, much of it in response to direct personal application.

During his entire public service, Dr. Saunders never relaxed his efforts. Himself a master of detail and an indomitable worker, he, as far as it was reasonably possible, kept his own hand upon the various undertakings of the several Farms. For many years, he planned most of the experiments and other work and saw that each was carried out according to the general principles of the established system. No new work was undertaken by the officers without his full approval, and no innovations were introduced without the permission of the presiding Minister. Much of the general agricultural work done at the Central Farm has been repeated more or less completely at all the Branch Farms and in this way a great deal of information has been gained as to the relative suitability of the more important farm crops to the different climatic and other conditions of the country. Valuable information has been acquired as to the adaptability of certain varieties for particular localities, the determining of which has taken many years of painstaking effort. 


\section{EXPERIMENTS WITH FERTILIZERS.}

There was concluded in I9Io a series of experiments that had been carried on for twenty-two years with the object of obtaining information regarding the results which follow the application of certain fertilizers and combinations of fertilizers on the more important farm crops. In this series much useful information has been gained for the benefit of those who care to study the work as published in the Annual Report of the Experimental Farms for I9Io. Merely to indicate the character and value of these tests, reference will be made to conclusions reached.

This investigation extended over three periods, the first during which fertilizers of various kinds were applied to lands for different crops from I 888 to 1898 ; the second during which fertilizers were discontinued and clover grown- 1900 to 1904 ; and the third when fertilizers were again used as in the first period.

Among the conclusions reached those respecting barnyard manure are of the greatest interest and value. It has been shown that this manure can be economically used in the fresh or unrotted condition; that fresh manure is equal, ton for ton, in crop-producing power to rotted manure. Since experiments have shown that losses during the process of rotting may amount to 60 per cent. or even more of its weight, and in view of the vast importance of making the best possible use of barnyard manure, it is difficult to overestimate the value of this one item of information.

In the second period, the value of clover as a fertilizer was clearly shown. In addition to the nitrogen gathered from the air, this plant adds to the amount of mineral plant food available, by collecting it from depths not reached by the shallower root-systems of other farm crops. It serves as a catch crop, retaining fertilizing material brought down by the snow and rain, and also that formed by nitrification of the soil itself, much of which would otherwise be lost. Clover also supplies the land with a large amount of humusforming material, which in its further decay deepens and mellows the soil.

In this work of the second period with clovers, the Director was very ably assisted by the Chemist, Mr. Frank T. Shutt, who with Dr. Saunders issued in Bulletin No. 40 a full report of the clover experiments. It was very widely circulated, and coming out at a time when the value of clover was only slightly understood, it proved of inestimable value to the cause of better farming. 
When these experiments were planned, the opinion was very generally held that untreated mineral phosphate (apatite) if finely ground became a valuable fertilizer, gradually giving up its phosphoric acid for the promotion of plant growth. It would appear from many years' experience, that the amount of phosphoric acid that would become available from such an application is extremely small. and therefore, from the practical standpoint, the finely ground Canadian phosphate rock cannot be consiclered a profitable fertilizer.

Sulphate of iron, which at the time these tests were begun, was highly recommended as a means of producing increased crops, has also proved to be of very little value for this purpose.

Common salt, which has long had a reputation for its value as a fertilizer for barley, with many farmers, while others disbelieved in its efficiency, has been shown to be a valuable agent for producing an increased crop of that grain, while it is of much less value when applied to crops of spring wheat or oats. Some light has also been thrown on the relative usefulness of single and combined fertilizers. Further references to the value and use of clover and yard manure are pulslished in the sections of this bulletin dealing with 'Farm Field Work,' and 'The Work of the Chemical Division.'

Even a cursory glance through one of the more recent annual reports of the Experimental Farms must convince any one that an almost endless number of experiments and lines of work have been undertaken. In this review it is practicable to refer only to the more outstanding investigations and other works that have been carried on for sufficient length of time to enable more or less reliable conclusions to be drawn. 


\section{WORK WITH CEREALS.}

The distribution of strong, pure seed of tested varieties of grain has been a prominent and valuable feature of the work of the Experimental Farms. Practically all of the wheat growing countries of the globe have been searched for new varieties that have been brought together and thoroughly tested side by side under similar and under varying conditions, first at the Central and then at the other Farms to determine their values and to perpetuate those found worthy for future distribution. Even before the Farms had been thoroughly organized distribution was commenced. The reputation of Ladoga wheat for earliness and yield had reached the knowledge of the Director from Russia where it was extensively grown. Samples were procured and submitted to millers, grain dealers, Boards of Trade and others interested, and by practically all of them pronounced to be of excellent quality. A large importation was then made and in $\mathbf{1 8 8 7}$, $2, \mathrm{I} 50$ three-pound bags of seed were distributed to individual farmers. This was the commencement of a work that has been the means of introducing into thousands of farms sorts of grain that have added immensely to the harvest returns of the country. It has been continued year after year, increasing in the number of samples sent out as time has gone on.

During the first ten years the Experimental Farms were in operation, the average distribution was about 10,000 samples of cereals and potatoes, amounting to about 60 tons per year. Since then the average per year has been about 38 ,ooo samples and in I9Io it reached 50,000 samples distributed from the Central and Branch Farms.

Ladoga wheat as compared with some of our best sorts possessed some defects, but on account of its earliness it has been used as a parent of excellent new sorts that have been evolved in the Cereal Division. A promising early sort known as Hard Red Calcutta was brought from India in the early days of the Farms, and while like Ladoga, it lacked some of the qualities of the best kinds, it has proved an excellent crossing variety. Other early Russian and Indian varieties have also been employed in this manner.

None of the imported, early-maturing varieties proved quite satisfactory, and it was decided therefore, many years ago, that new types must be produced by cross breeding and selection in order to secure the most suitable sorts for the northern sections of Canada. To this phase of wheat improvement the Cerealist has devoted most of his time for a number of years past.

$$
32880--2 \frac{1}{2}
$$


In the breeding of wheats, three chief qualifications have been kept in view, viz. productiveness, earliness and milling and baking qualities. Of the thousands of hybrids that have been produced, none has been retained (for propagation as a bread-making wheat) that lacked these qualifications. Thousands of new kinds of wheat have been bred, most of which were rejected while they were still single plants. Others have been grown in small plots, and others again in larger plots, sometimes for several years. A few of the best have been tried at other farms, and subjected to milling and baking

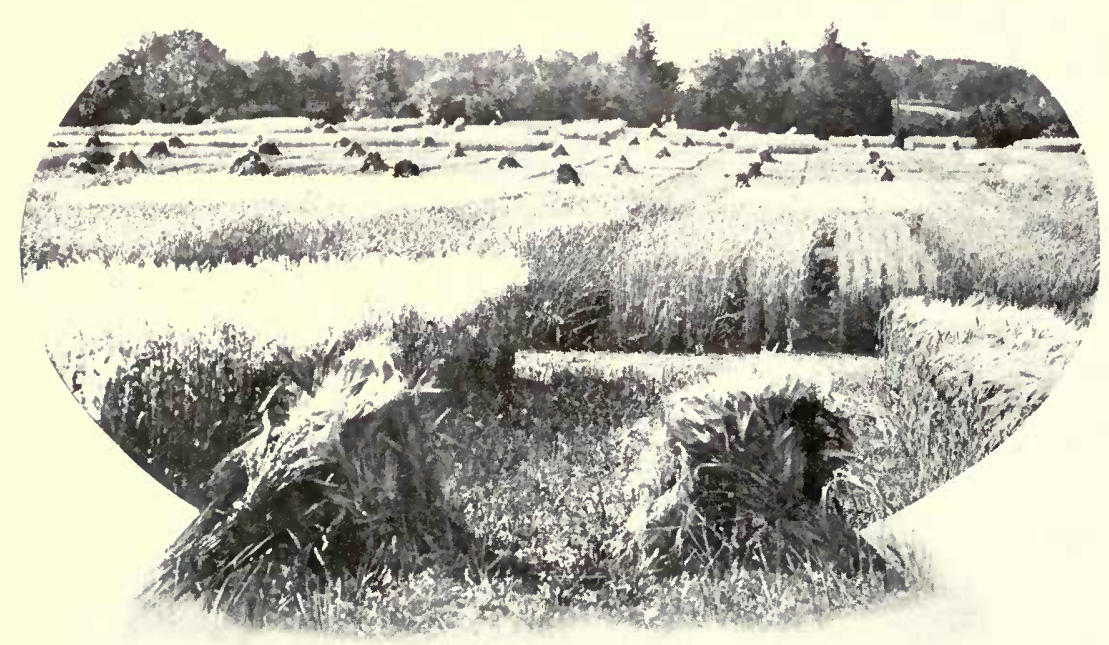

Experimental plots at the Central Farm.

tests also. Altogether about a dozen varieties so far have been introduced to the public,--some of these only for special and peculiar conditions. Of these varieties special reference might be made to four which are now well known and are valuable to farmers who cannot ripen the old standard varieties--Red Fife and White Fife. These four wheats are all Fife crosses. Three of them are of similar parentage and fall into one group, viz.: Preston, Stanley and Huron.

These three varieties differ in certain respects, but are all of a vigorous and productive habit and early in ripening. Preston and 
Huron are both bearded, Preston having pale chaff, and Huron reddish. Stanley is a bearless wheat. Preston and Huron are fully equal to Red Fife in hardness and in depth of colour of kernel, but Stanley is perhaps not quite so hard, as a rule. In none of these three is the flour quite equal from a commercial point of view to that made from Red Fife. They make very good bread indeed but it is not so pale in colour or so light in texture as that made from Red Fife or White Fife. These new varieties are therefore at a disadvantage in those provinces where much emphasis is laid on baking qualities.

The fourth sort is newer than these others and of different parentage. It is derived from one of the crosses between Red Fife and Hard Red Calcutta made on the Experimental Farms many years ago. In the year 1903 an unfixed mixture of related types, descended from this cross, was subjected to careful selection by Dr. Chas. Saunders, the Dominion Cerealist. He isolated several types and gave the name 'Marquis' to the best of them. He propagated this variety from a single plant of the year I903. Except for earliness, this wheat is almost indistinguishable from Red Fife in the field and in its action in the mill, and in the bakery; so that it combines in itself to a high degree all the advantages looked for. It retains essentially the Red Fife quality in baking, and at the same time it shows a distinct advance in earliness. It ripens with Preston, that is to say, from five to ten days or more before Red Fife.

In yield it varies considerably in different provinces. In the eastern parts of Canada and in British Columbia it has given good results but has not as a rule shown any unusual productiveness. But in the provinces of Saskatchewan, Manitoba and Alberta, it has produced remarkable yields, and the reports sent in by farmers who have received samples have been almost invariably enthusiastic. Not only does Marquis ripen earlier than Red Fife but it better withstands adverse conditions such as wind, wet and rust and produces larger crops of heavier weight per bushel and better appearance. In plot tests at Indian Head, Marquis gave 50 per cent. more grain than Red Fife in the average of the first five years. At Brandon a fouryear test showed ro per cent. greater yield from Marquis. The best field records are those made in 1909 at Brandon, where a four-acre field gave something over 200 bushels of crop, and in I9Io at Indian Head where a five-acre field gave an average yield of over 53 bushels per acre.

TRIUMPHS OF MARQUIS.

The Marquis wheat has created a remarkable sensation in the West. Applications began to come in the autumn of 1909 in unusual 


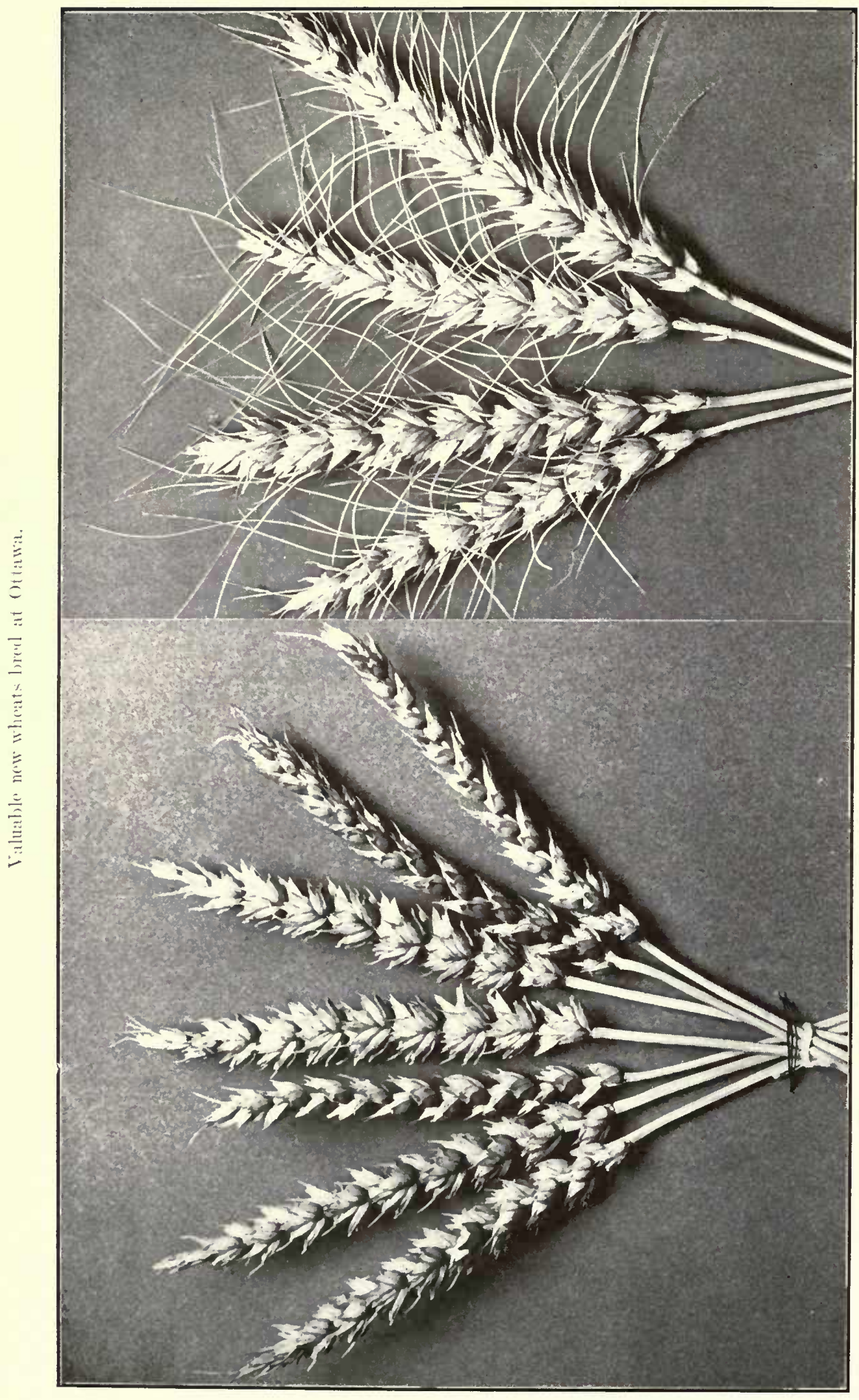


numbers, and ever since then the demand has been very great. It was quite impossible for some years to meet the request for this variety. Many farmers expressed themselves willing to pay any price for a few bushels of the wheat. The highest specific offer made was $\$ 50$ for ten bushels, but large quantities have changed hands at $\$ 3$ and $\$ 4$ per bushel. On account of its surpassing excellence Marquis wheat is rapidly replacing all the older early maturing varieties, especially in Saskatchewan, and is to a large extent supplanting Red Fife also.

Perhaps the most noteworthy triumph of Marquis wheat was the winning of the prize of one thousand dollars at the Land Exhibition in New York City, in the Fall of I9I I, for the best Ioo lbs. of wheat grown on the continent of North America. The winning grain was grown by Mr. Seager Wheeler of Rosthern, Sask., from seed supplied by the Experimental Farms. This success is especially noteworthy inasmuch as the year I9I I was one of the most unfavourable seasons known in Saskatchewan in a wheat-growing period of over 30 years; and the Rosthern district has sometimes been regarded as unsuitable for the production of wheat of the highest quality.

At the Dry-Farming Congress, held at Lethbridge, in October, I9I2, Marquis wheat again demonstrated its superior quality. In competition with wheat grown in any part of the world, a bushel of this variety won the championship prize of a farm engine valued at $\$ 2,500$. The winning wheat was grown on irrigated land by Mr. H. Holmes, of Raymond, Alberta.

Red Fife being the standard high grade wheat in Canada, has been used to a large extent for crossing to produce new varieties. In addition, an effort has been made by applying the best methods of selection to secure improved strains from it. In this way there have been obtained two important types, Red Fife H. and Early Red Fife. Red Fife H. is very slightly earlier than the ordinary Red Fife, perhaps from one to four days on an average, and baking tests have shown it to be absolutely of the highest standard. Early Red Fife shows greater earliness (about five to ten days). It has been baked several times and has proved to be the same as ordinary Red Fife in baking strength as well as in most other respects. Its earliness is, however, a distinct advantage. Unfortunately it has shown a greater susceptibility to rust in most (but not all) districts in the Prairie Provinces and its cultivation there is not now advocated. Marquis has proved distinctly superior. In eastern Canada, however, Early Red Fife succeeds very well and seems likely to prove a valuable acquisition, superior perhaps to its great rival.

This work has been done more especially to meet the needs of the Northwest, for earlier maturing varieties. Although good success 
has been attained in selecting Red Fife for increased earliness and in producing early ripening cross-bred varieties, some of which are of very great value, nevertheless the work is being continued. About fifty new cross-bred varieties of considerable promise reached the stage for baking tests in 1909 and over roo in I9Io, and the Cerealist expects to have approximately one or two hundred more during the next few years. Out of these three or four hundred new varieties, this officer expects to be able to select a few sorts which will be in adrance of the best yet produced, from the point of view of those districts where the sumner is short.

OTHER GRAINS.

In the matter of producing new sorts of grain, the work has been confined chiefly to wheat. Very important work, has, however, been accomplished with other kinds of grains and field crops. As with wheats, varieties of oats, barley, peas, rye, etc, have been secured from every available source and tested in plots. Those that fail to reach a certain standard of excellence are discarded while the better sorts are submitted to further test on sufficiently large areas to prove their worth. By the process of elimination only promising introductions are retained, and the best of these are cultivated on a large scale so as to admit of their free distribution for the use of growers in different parts of the Dominion. In barley and oats, many new sorts have been produced, special attention being paid to hull-less and leardless kinds and to those varieties of very early maturing halit. New cross-bred peas have been produced including a number of varieties of the Crown type.

For the past seventeen years, a special annual bulletin has been issued giving the results obtained on all the Experimental Farms from trial plots of grain, fodder corn, field roots and potatoes. In this Lulletin the varicties are arranged in tables in the order of their average yield for a number of years. Through this medium, farmers in all the provinces are able to learn of the sorts that yield best in their respective parts of Canada, and if they are not able to readily procure seed of these sorts for a large acreage they can at least procure samples from one of the Farms, from which they can very soon produce a large stock. It is through this branch of the work of the Experimental Farms that Banner Oats and Mensury barley became so generally grown over the Dominion, a number of years ago. And while attractive, new sorts, have been in more recent years brought out, these two old kinds are still being adhered to in many parts of Canada. 


\section{FODDER GROPS.}

To the work of the Experimental Farms is due the introduction of a number of the most valuable fodder crops now grown in Canada.

GRASSES.

At the time the Farms were organized, there was a serious dearth of grasses suitable for the Prairie Provinces. When searching for hardy wheats, Dr. Saunders was also on the outlook for fodder crops that would withstand cold latitudes. He well understood the necessity for alternating grasses with cereals in the West in order to maintain a productive soil. As early as 1887 , there was received from Riga, Russia, along with a shipment of Ladoga wheat, a supply of seed of Awnless Brome grass. This was sown in plots under the charge of Dr. Fletcher and it gave such promise as justified its trial on a more extended scale. It proved a heavy cropper and very hardy, not only at Ottawa, but also at Brandon and Indian Head. On the two western Farms, it proved a most persistent producer of excellent fodder and, as its good qualities became known, it spread to all parts of the West unti] it now ranks with the best grasses grown for pasture and for hay. Its strongest rival apart from timothy in the Western Provinces, is western rye grass, a native perennial, that was discovered by Dr. Saunders and one of his officers during the course of a drive in that country. Seeds were gathered and sown at the Brandon Farm and at Ottawa, where it gave excellent promise. Very soon both Rye grass and Brome grass were being grown on a scale sufficiently large to make possible the distribution of seed to a large number of farmers. From that period until now the area devoted to these crops has been constantly increased until they occupy a position in the agriculture of the Prairie Provinces similar to that held by timothy in the older provinces.

\section{CLOTERS.}

In the early years of the West, the growing of clovers was despaired of because of the severity of the climate. Through the persistent efforts of the Director and his officer, methods of successfully growing both Common Red Clover and Alfalfa have been discovered at both Brandon and Indian Head and already these crops are entering into the rotations of many western farms. If the Experimental Farms in western Canada had done nothing more than lead 
the way to the growing of clovers as a general crop in these provinces, they would have fully justified their existence.

CORX.

The extension of the employment of corn for fodder purposes that has taken place in Canada during the last two decades has been greatly helped by the work of the Experimental Farms.

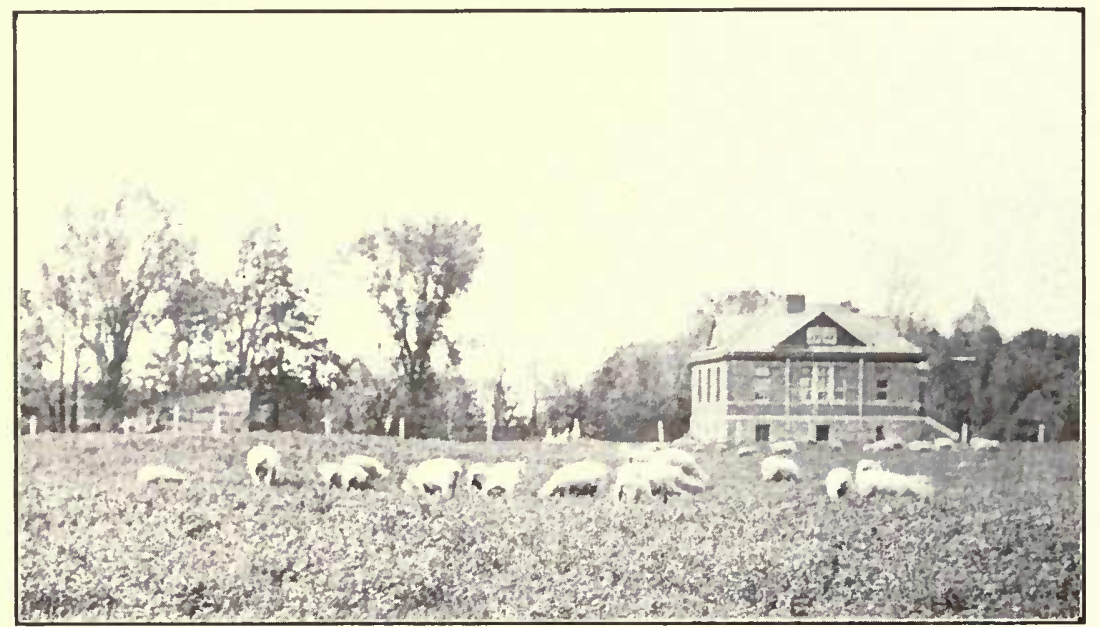

Shere pisturin? on two-year old alfalfa.

In districts where a long summer season prevails, the growing of corn is a comparatively simple matter, as almost any variety will reach a stage of sufficient maturity to make good fodder, but in many parts of Canada, in fact in practically every province, the question of suitable varieties and of methods of cultivation are of prime importance. In the Maritime Provinces and in Quebec, very few of the heavy yielding sorts will mature, and this is doubly 1rue in regard to the Prairie Provinces. The location of the Central Farm at Ottawa enables it to serve much of Quebec and northern Ontario, while the Maritime Province Farms are able to settle the questions of sorts and of methods of cultivation for these eastern provinces. On certain of these Farms, as well as at the Brandon and Indian Head Farms, silos have been in use for many years for the storing of fodder for stock. The experience with these has been of great assistance in determining the most suitable varieties for growing in cool sections. The information that has thus been gained and sent out to the country has been of great value to the stock raising industry. 
It is only comparatively recently that corn growing has been taken up on the farms of the Prairie Provinces. As it becomes known, it will be more generally grown. It is not a new crop in these provinces because Indians grew it a very long time ago and it has been on trial at the Experimental Farms for many years, where it has proved its worth. To secure great bulk of crop, farmers here and there have tried some of the late varieties. The Experimental Farms have proved that earlier sorts, while producing less bulk, yield a crop of infinitely better quality. By careful test, varieties have been found that will yield from I 2 to I 5 tons per acre of green crop that generally reaches the milk or dough stage by the date the crop should be put into the silo. Longfellow, Compton's Early, North Dakota White and Northwestern Dent have all proved satisfactory in Manitoba, while Eureka, Angel of Midnight, Compton's Early, Longfellow, and a number of others do well in Saskatchewan. The information acquired at the Experimental Farms and spread throughout the western provinces, in regard to the growing of fodder corn and its conversion into silage will undoubtedly prove a strong factor in developing the live stock industry, without which no country can long continue to raise wheat profitably.

The Central Farm has taken a leading part in the extension of the silo and the use of soiling crops more especially in Eastern Ontario and Quebec, while the Nappan Farm has done much to popularize the use of silage farther east. Whereas the silo was rarely seen in these sections of Canada a dozen years ago, every dairying section is now dotted with silos that are greatly appreciated. The Experimental Farms have demonstrated over and over again beyond the shadow of a doubt that cattle, especially, can be fed much more profitably by the aid of silage than without it; that, when suitable varieties are planted and the crop is properly cultivated and handled, a good crop can be assured every year on almost every kind of welldrained land; that all kinds of farm stock relish silage when properly prepared, and that silage is an available fodder twelve months in the year.

These facts have not only been demonstrated but preached from the Farm in season and out of season, by bulletins, reports, interviews, public addresses, the public press and by correspondence until the name of silage to many a man who has proved its value is at once associated with the Experimental Farms. 


\section{FARM FIELD WORK.}

It has been observed from the very beginning of the Experimental Farms that methods of cultivation are quite as important from the crop standpoint as the rarieties and qualities of seed planted. At the Central Farm and at each of the Branch Farms year after year experiments have been carried on to determine the very best methods of growing the various crops. This work has had reference to crop rotation, manuring. thoroughness of cultivation, thickness of seeding as well as clrainage and a number of other factors.

ROTATION.

While many factors necessarily unite to produce the most satisfactory results in keeping up the condition of a farm, it has been recognized by the Director and his officers that no single practice can compare in importance with a proper system of rotation of crops. It has been recognized that the rotation or rotations adopted necessarily depend upon the system of farming followed and to some cxtent upon the character of the soil and the physical peculiarities of the farm as a unit. The work of the various Farms has therefore varied to some extent according to the conditions of agriculture prevailing in the province served by each respective Farm. At the Central Farm rotations and systems of cultivation have been worked out for conditions of mixed farming where live stock raising forms a leading branch. At the Brandon and Indian Head Farms, on the other hand, rotations have been studied chiefly from the standpoint of the grain farmer. At each Farm, the work has been carried on in the light of the food requirements of different crops and to somc extent, of the values of the residues from the difierent crops included. It is urderstood that certain forage crops such as corn, roots, potatoes and ray rcquire an immense amount of food for stem, leaf and root production - that is, an abundance of nitrates as found in the sod of clover and other crops and in wellmanured land. Other crops, such as cereals, can get along best with a lighter supply of nitrates which, when present in excess, tend to produce a superabundant growth of straw or vine to the delay of ripening. These crops, therefore, need more phosphates, hence do well after some forage crop has taken up the excess of free nitrates found after sod. In the light of these points, it is evident that a good rotation for a system of mixed farming will include (I) meadow 
or pasture land, (2) roots or corn and (3) some cereal crop; and for a grain cropping system, the growing of leguminous crops from time to time to be turned under as green manure.

At the Central Farm, it has been demonstrated by Mr. Grisdale, who was Agriculturist for twelve years, that various combinations may be safely adopted. The natural aim of his experiments has been to determine ( $\mathbf{I}$ ) the comparative values of rotations as soil improvers, and (2) their relative suitability for different lines of farming.

Side by side, year after year, at the Central Farm, various rotations have been followed in plots of equal size. From immediate

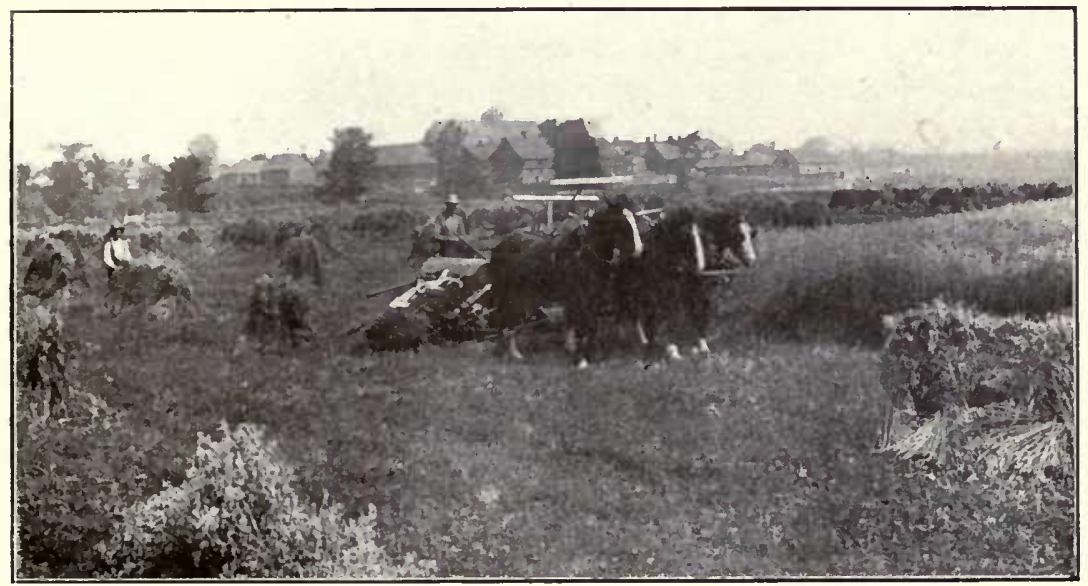

Harvesting oats at the Central Farm.

crop returns and for other reasons, Mr. Grisdale, after an experience of twelve years, pronounces favourably upon the following five year system:-

First year.-Land ploughed in August, well worked, ribbed in Cctober; seeded next spring to oats, and ro lbs. clover sown per acre; allowed to grow one year and turned under as a fertilizer for corn.

Second year.-Manure, applied in winter or spring, 25 tons per acre; shallow ploughed, corn planted.

Third year.-Grain, seeded down, 8 lbs. red clover, 2 lbs. alsike, Io to I2 lbs. timothy per acre.

Fourth year.-Clover hay, two crops expected.

Fifth year.-Timothy hay.

Other rotations tested are almost equally valuable, particulars regarding which are fully given in the Experimental Farms' Annual Reports. 
Then, again, rotations have been worked out for various systems of farming, as, for example, with hogs as a leading factor or with sheep as the chief stock kept. Then a number of three year systems have been tested; the results from these as given in the Annual Reports may be taken as authoritative.

( $p$ to the spring of 1899 , the rotation experiments conducted at the Brandon and Indian Head Farms were of limited range. That spring a series was commenced at these Farms to determine the value of leguminous crops for turning under every third year as compared with that of the usual bare summer-fallow, for maintaining the fertility of the soil. At Brandon, seventeen, and at Indian Head twenty-two, rotations or combinations have been under test for a number of years. The average and total yield of each variety of grain on each plot has been worked out for the number of years each has been sown, and the revenue found from each plot for a five-year period at Brandon, and an eleven-year period at Indian Head. Wheat was valued at 90 cents, oats at 45 cents and harley at 50 cents per bushel. The results were as follows :-

At the Brandon Farm, the cropping system that gave the highest return was, wheat, Ist and 2 nd years; summer fallow 3 rd year and wheat $t_{\text {th }}$ and 5 th years. The return per acre was \$I43.62. The next most profitable was wheat, Ist and fth years, oats 2 nd and $5^{\text {th }}$ years, and peas ploughed down 3 rd year; the total return for grain was SI31.26 per acre for the five years.

At the Indian Head Farm, the work with 22 systems was in operation I I years. The greatest return per acre during the period was obtained from a plot that grew wheat for 8 years and oats for three years and amounted to $\$ 223.54$. The most profitable system in which a leguminous crop was ploughed down was wheat, oats, soya beans ploughed under, wheat, oats, peas ploughed under. It is pointed out by Mr. Angus McKay, the Superintendent, that good results obtained from continuous grain growing are possible only on comparatively new land and are obtained at the cost of the exhaustion of the fertility of the soil. This is amply demonstrated in the report of these experiments which shows that where the growing of grain has been continuous the crop on the average has been reduced. The only exceptions were found to be the result of unusually favourable seasons.

MANURING.

The experience of Dr. Saunders, extending over a quarter of a century, lead him to the conclusion that on the average farm in 
Canada, barnyard manure in conjunction with a judicious rotation, was the most economical and effective material for increasing crop yields and the upkeep of soil fertility. There is no substitute for farm manures, but there are cultural systems in which these may be supplemented by commercial fertilizers with profit. Methods of "intensive" farming call especially for large amounts of immediately available plant food, and these can best be supplied by the use of those more or less soluble compounds of nitrogen, phosphoric acid and potash found on the market as nitrate of soda, superphosphate, muriate of potash, etc. In orcharding and market gardening more particularly, fertilizers, in addition to stable manures, have been found profitable and there is little doubt but that their use will steadily increase in districts devoted to the more intensive forms of agriculture.

It has been found that the most important material making for soil fertility is humus. Increasing the decayed or rotten vegetable

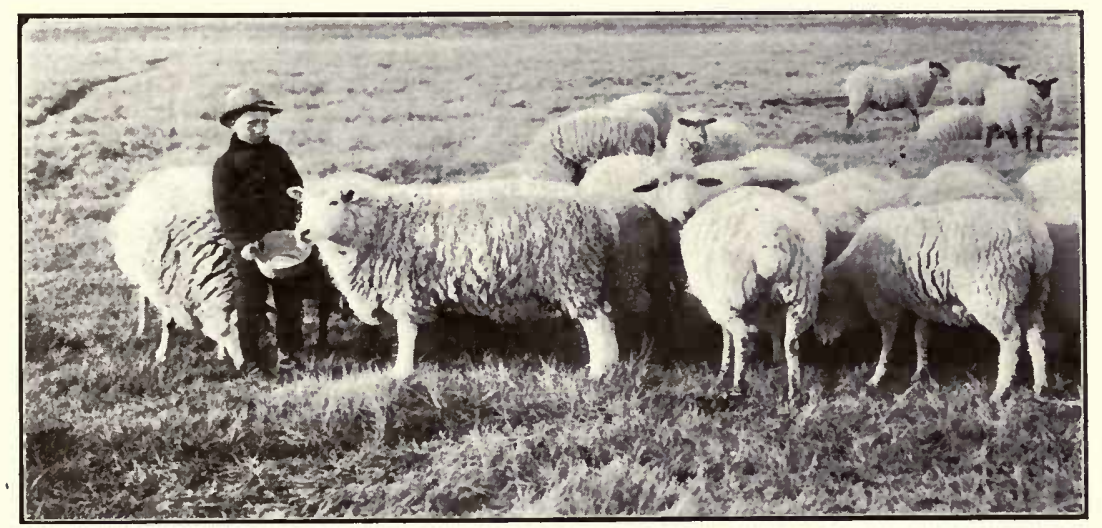

The junior shepherd with his flock.

matter in the soil is worth infinitely more than adding any amount of commercial fertilizer, or of plant food in the form of mixed fertilizer. Getting this humus into the soil and following a suitable rotation are the most important considerations. For instance, a three-year rotation leaves a fine clover sod to turn under when it is in its very best form. Experiments at the Central Experimental Farm during the last few years have demonstrated that such clover sod is worth from \$IO to \$I2 per acre to the crop following it. If in addition to this clover there can be added a considerable amount of barnyard manure, then we have very nearly ideal conditions. The application of barnyard manure at short 
intervals rather than in larger quantities at long intervals, is proved to be the better plan.

CULTLRAL OPERATIONS.

After the rotation has been fixed upon and the fertilizer has been at least anticipated and arrangements made for its application, the proper performance of all cultural operations at the right time-that is, the suitability, thoroughness and timeliness of cultural operations-is the next consideration. Many lose time in spring by slowness in getting out on their land. It is possible, of course, to start operations too early, but one must know enough of his business to be able to judge when his land is ready for the application of fertilizers or when it is fit for seeding, and then the great point is to get the seeding done as soon after the land is ready as at all possible. Earliest seeding will mean anywhere from five to ten per cent increase in yield, as has been demonstrated over and over again at the Experimental Farms. We cannot control the moisture content until we begin to work, but we can provide for taking off the surplus surface moisture and when we do that the temperature of the soil is raised.

Thoroughness of all cultural operations is an exceedingly important point. The man who harrows, or ploughs or cultivates, in a half-hearted kind of way gets a half-hearted kind of crop every time. This has been proven over and over again at the Experimental Farms. After cultivating until one would think the field must be sick of the process, or until it looks as though one had overdone the thing and were adding unnecessarily to the expense of the preparation of the soil, it is usually well to do a little more.

SEEDING.

Experience has taught that drilled grain gives a better crop than that sown broadcast. About 7 inches between the drills has been found at the Central Farm to be the best distance.

The quality of seed to sow per acre has received a good deal of attention, but still no very positive conclusions have been reached. It is decided to be a safe rule to sow a moderate quantity, that is to avoid very thin or very thick seeding. In a moist season thin seeding is usually sufficient while in a dry one enough should be put in to allow for the failure of a portion of the seed to produce a vigorous plant. At the Central Farm $2 \frac{1}{2}$ bushels of oats, 2 bushels of barley and 5 pecks of wheat is looked upon as about the right quantity of each crop to sow per acre. 
For seeding down for mixed hay, Mr. Grisdale recommends Io lbs. of red clover 2 or 3 lbs of alsike and Io to I 2 lbs. of timothy seed per acre.

\section{DRAINING.}

The value of a good system of drainage has been amply demonstrated at the Central Experimental Farm. Thirteen years ago it was decided that forty acres of this Farm was insufficiently drained. During the autumn of that year a good system of underdrains was put in with the result that the following year the increase in the value of the crop was fully one thousand dollars. Every year since that time this portion of the Farm which previously gave very uncertain crops has produced well. By means of surface grading and underdrains practically every foot of land on the 200 acre farm has now been brought under profitable cultivation.

The system complete comprises about seventeen miles of tile drains, made up for the most part of $3 \mathrm{in}$. and $4 \mathrm{in}$. laterals, which lead into mains ranging from 6 in. to 12 in. in diameter, depending upon the total area they drain and the slope obtainable.

Except for the purposes of making grade the tile have been laid on the average $3 \mathrm{ft}$. deep, and in distance apart they range from 30 $\mathrm{ft}$. to Ioo $\mathrm{ft}$. On the heavy land with hardpan subsoil, it has been necessary for best results to lay parallel lines as close as $30 \mathrm{ft}$. while on the lighter soils fewer lines were required for equally good results. Generally speaking the heavy clays and mucks have been drained 30 $\mathrm{ft}$. to $50 \mathrm{ft}$., clay loams $50 \mathrm{ft}$. to $75 \mathrm{ft}$., and the lightest of the soils $75 \mathrm{ft}$. to Ioo $\mathrm{ft}$. apart.

Owing to slow grades, and to the fact that there are great variations in soil types on the Farm, making it necessary for nearly all the mains to pass through very sandy soil at some point in their course, it has been necessary to establish sand traps at various intersections throughout the system. Many of these are built of concrete. The large amounts of sediment removed from these basins from time to time indicate their usefulness under such conditions as obtain at the Central Farm.

According to the Director of Experimental Farms thorough under drainage may cost from $\$ 20$ to $\$ 40$ per acre but even at the extreme figure it has been a paying investment for practically worthless fields have been converted into profitable producing areas. 


\section{EXPERIMENTS WITH LIVE STOCK.}

The chief experimental work with live stock carried on by the Experimental Farms has been confined to cattle and swine although tests have been made in the use of different rations for working horses.

In I 889 , herds of five breeds of cattle were established at the Central Farm, made up of Shorthorns, Ayrshires, Holsteins, Jerseys, and Aberdeen-Angus. A few years later, Aberdeen-Angus, Jerseys and Holsteins were displaced by Guernseys and Canadians. In I9I I foundations were laid for herds of Jerseys and Holsteins. In I 890 , swine were introduced including Yorkshires, Berkshires and Essex. Since then, several other breeds have been experimented with, but, for several years, all have been abandoned except Yorkshires, Berkshires and Tamworths.

At each of the other Farms, there have been maintained, almost continuously since their inception, herds of beef and milking cattle and of swine. At the Brandon, Indian Head and Nappan Farms, tests in feeding beef cattle have been carried on from year to year. At the Nappan Farm, series of tests were also conducted to determine the most profitable methods of feeding steer calves.

At the Central Farm, exhaustive experiments have been carried on year after year with beef cattle, dairy cattle and swine. With each class of stock, thousands of animals have been involved. The work has been done in the most practical way, directed by an understanding of the scientific principles that underlie feeding.

BEEF CATTLE.

Both at Ottawa and at the Branch Farms, it has been demonstrated beyond the shadow of a doubt that good cattle are always the most profitable to feed. That is to say the good ones not only make more rapid gains on a similar ration but they put on flesh where it is most valuable to the butcher. By 'goodness' is meant well-bred. The more nearly the breeding stock conforms to the ideal beef type, the more certain is the progeny to yield a profit, and the better the animal, the greater the return.

It has been shown also that condition at the beginning of fattening has a marked influence upon the ultimate profits secured, feeders carrying the most flesh, up to a reasonable limit, yielding the greatest net return. 
At the Central and Nappan Farms, steers two years old have made the most rapid and profitable gains. While at that age they have reached the stage of sufficient maturity to appropriate a good portion of their food to fattening, they are still making fairly rapid growth of frame and muscle. At Brandon and Indian Head, cattle purchased when a year old proved the most profitable feeders. This was especially marked with cattle fed during the winter at. Brandon in the open air with only a thicket of trees for shelter.

For a number of years, a study of the influence of age on the cost of making gains, or increasing the weight of steers, was under inves-

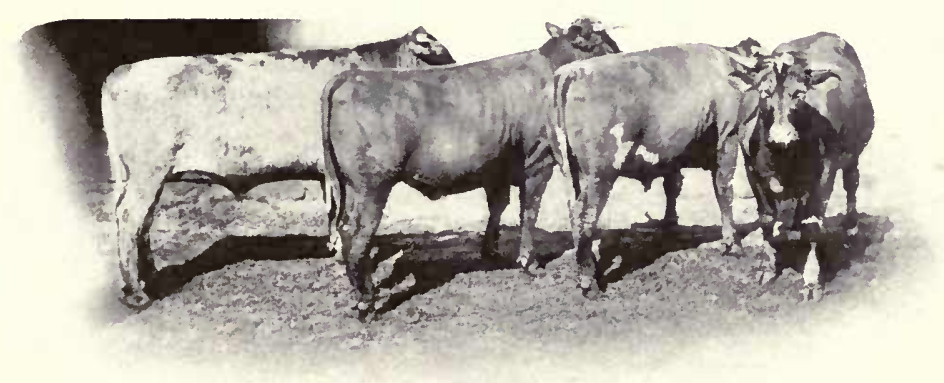

Baby beeves.

tigation. These experiments have shown a fairly regular gradation of cost according to age, that is, the older the animal and the longer on feed, the more expensive it is to make a pound of increase in weight. The cost per I oo lbs. has ranged about as follows :-

From birth to 6 months.....\$2.24

From 6 to 12 months.......\$4. I I

From 1 to 2 years....... \$5.49

From $2 \frac{1}{2}$ years to 3 years....\$6. I 7

From $3 \frac{1}{2}$ to 4 years.......\$7.97

In the fattening period, it was found that early gains are much more cheaply put in than later gains, but it is the finishing or later gains that raise the selling price per pound.

Experiments in housing have involved feeding animals when loose and tied, in roomy quarters and in cramped quarters and in stables well ventilated and poorly ventilated. It has been found that steers do better loose than tied, in groups not more than seven or eight head of about equal size and strength, allowing each animal about 70 square $32880---3^{\frac{1}{2}}$ 
feet of floor space. Tests have shown that much value is attached to allowing the eattle sufficient light, ventilation and comfort. An extended series of tests with degrees of ventilation have proved that faulty rentilation costs money erery time.

In preparing cattle for winter fattening, it has been found profitable to feed liberally until cold weather on a succulent fodder such as rape, then to feed ensilage, roots, straw and hay. Unless the cattle are half fat and to be finished early, it has been found most profitable

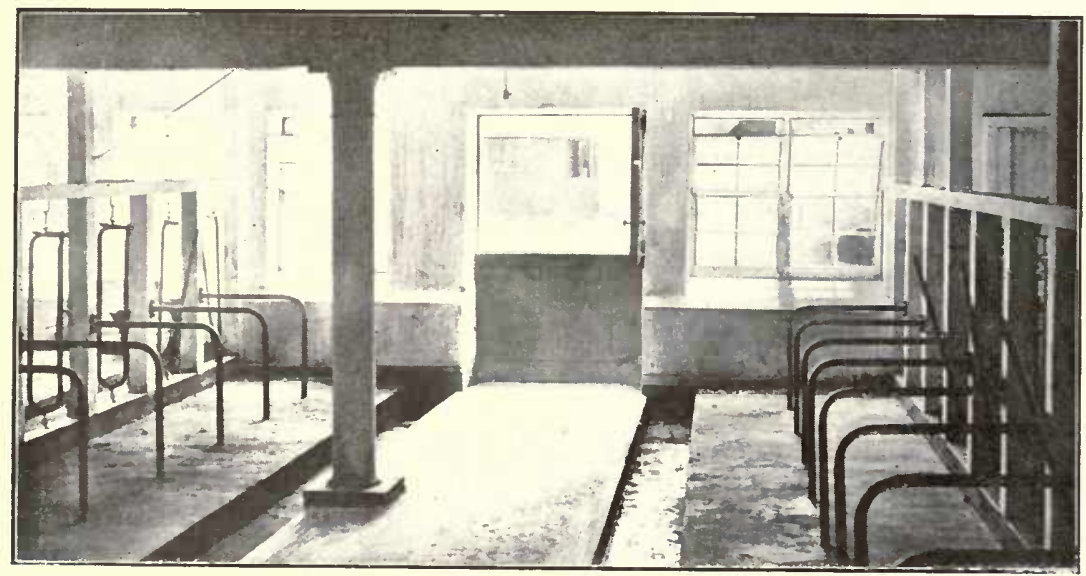

Section of main dairy barn showing stalls for cows.

to withold the grain ration for three or more weeks, then commence with a light ration, chiefly bran. The feeding of heavier meals should be commenced lightly and increased very gradually. Corn meal, gluten feed and oil meal with bran has given best satisfaction, but any coarse grain is good when fed by an experienced feeder.

Feeding for short or longer periods has received much attention. Reference to one test fairly represents the conclusions reached by Mr. Grisdale in a long series of experiments. Each lot consisted of seven head.

One lot was fed for I 30 days and the other lot for I 80 days. One lot had to be considerably fatter than the other when put in. The other lot was quite as good, but thinner. In the case of the 'long feed,' it cost $\$ 4.26$ to make I oo pounds gain, while in the case of the 'short feed' it cost $\$ 4.58$. Further, it took more meal per day in the case of the short feed. The gain in the case of the long feed was 2.36 pounds per day; in the case of the short feed 2.08 pounds per day. The short feed lot, being fatter when they started, were harder to induce to put on additional fat. The total cost of 
feeding these steers was \$I2.22 per steer in the case of the short keep and \$20.95 per steer in the case of the long keep, which were fed a good deal longer time. The selling price was $\$ 5.75$ per I oo pounds for the long keep and $\$ 5.50$ per Ioo pounds for the short keep. There was realized \$I 2.69 profit on the short keep and \$I 8.23 on the long keep steers.

In Manitoba and Alberta, experiments were made to determine the relative cost of fattening cattle in comfortable stables and in the

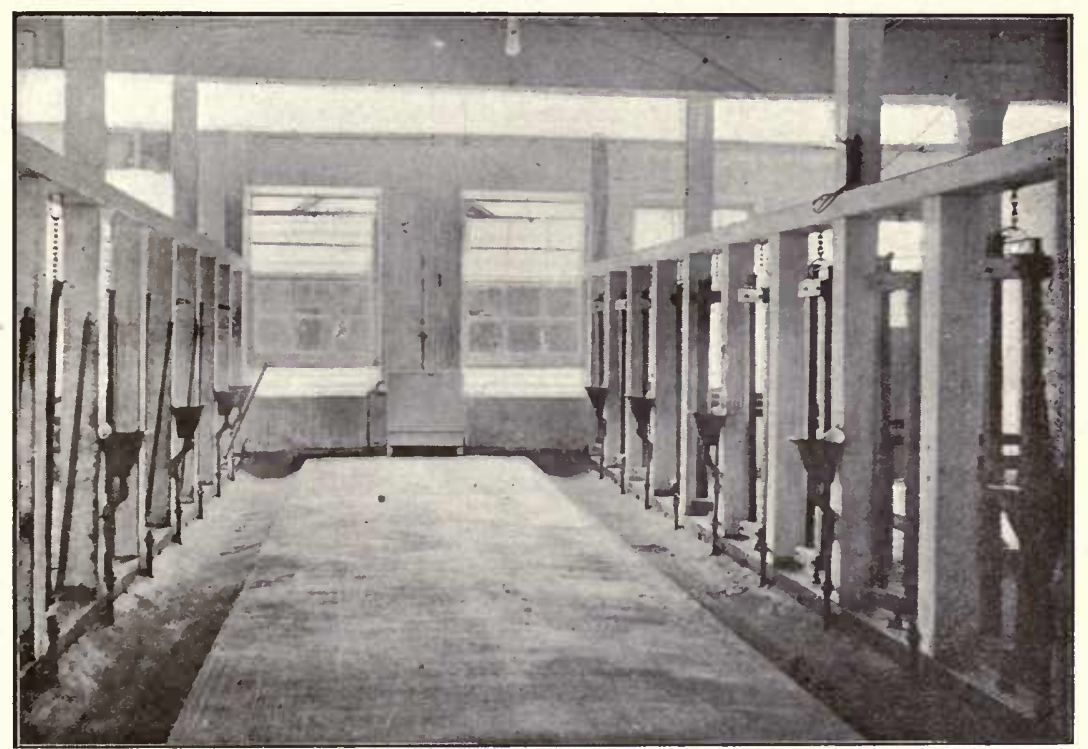

Section of main dairy barn showing mangers and water cups.

open air with only bush shelter. In Manitoba, in one test, it was found in the case of well-grown steers, three years and over, in fair flesh in the fall, that cheaper gains were made by the cattle fed out-of-doors. Younger cattle and those in lean condition are more profitably fed within the shelter of a barn. In Alberta, the threeyear-old cattle in fair condition fed out-of-doors made much more profit than those wintered in a comfortable barn.

Most of the feeding experiments already referred to were with cattle purchased as feeders. For a number of years tests were made to ascertain the most profitable method of feeding from birth to the finished condition. Steers have been finished within periods ranging from 13 to 14 months, and in almost every case, the greatest profit was obtained with those finished in the shorter period. Continuous fattening, when compared with carrying stock on a light ration, 
including very little grain the first winter none the second, and fattening the third, has shown conclusively that the former system is much the more profitable.

DAIRY CATTLE.

During the past ten years, a very large amount of experimental work has been carried on at the Central Farm with dairy

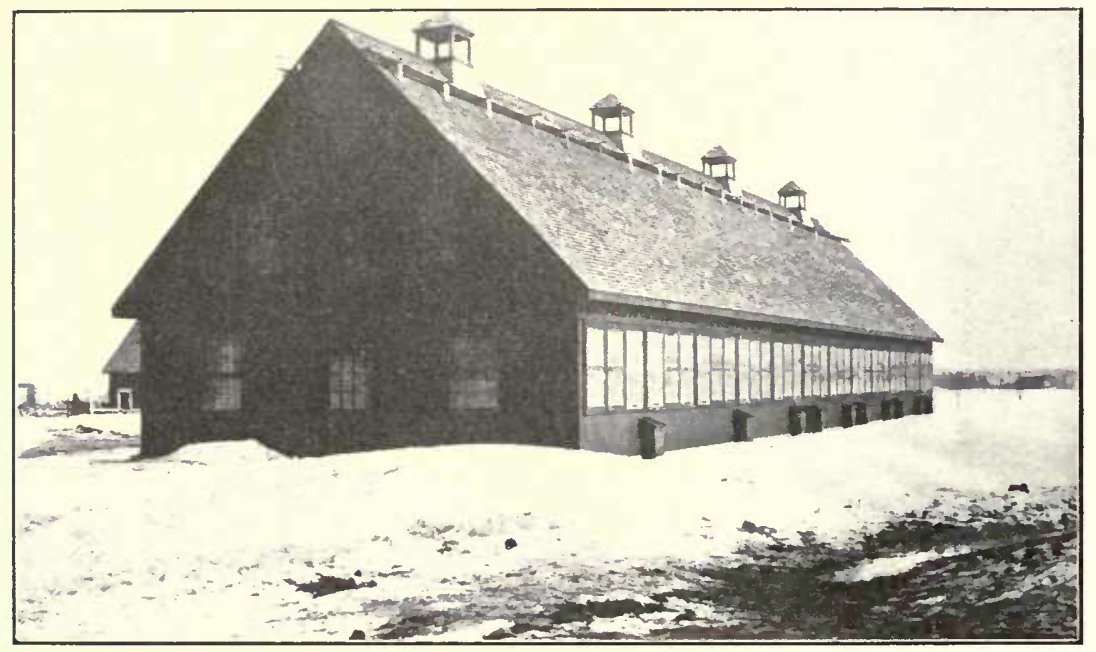

The new piggery. (Note the provision for light and ventilation.)

cattle. During this time, there has been continuously maintained herds of Ayrshire, Guernsey, Canadian, Shorthorn and grade cattle. These amounting to upwards of fifty head of milking cows, are kept in such a way as to do their share in securing a large revenue from the ' 200 acre farm.' With this object in view, the greatest care is exercised to keep the herds up to a high standard and by careful experimental work, to learn the most profitable methods of breeding, feeding and caring for the animals.

The herds were established upon carefully selected foundation stock all of which, except the Canadians, and grades were imported from Great Britain. The foundation stock of the Canadian herds was secured in the Province of Quebec. From time to time, as required, stock bulls from high producing dams in good herds have been introduced. Careful records are kept of the feed given to each animal, as well as the milk she gives, and the amount of fat it contains. From the information thus obtained, the best cows are recognized and kept 
on year after year for milking and breeding and the poor or unprofitable ones discarded. By this system of elimination, the production per head has been greatly increased. The herds at present contain practically nothing but high producing animals.

During the summer months, pasture is depended on to only a slight extent, the summer fodder consisting chiefly of soiling crops and corn silage with a grain ration. The soiling crops usually consist of grasses, and clover including alfalfa, green oats and peas and

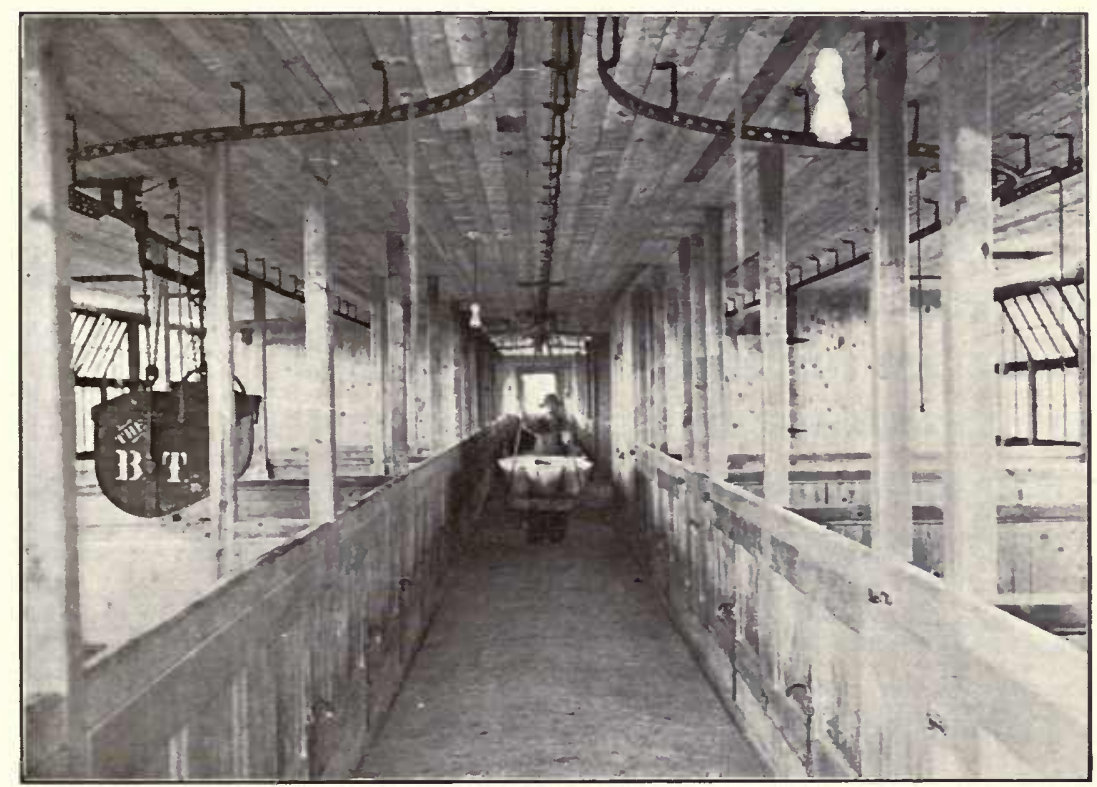

Interior of new piggery.

corn. Ensilage is much used at almost all times of the year. With these and other coarse foods, the cows are generously supplied, while the kinds and quantities of grain foods given are guaged by the quantity of milk each animal is giving.

The feeding during the winter varies from that in summer by substituting hay, straw and roots for pasture and soiling crops. The average winter ration found most satisfactory consists of hay 5 lbs., corn ensilage 30 lbs., roots Io lbs., straw 4 lbs., and meal 7 lbs. per day per cow. The hay is usually clover and timothy; the roots-mangels, sugar beets and turnips; the straw-oat straw and the meal, 8 parts bran, 3 parts gluten meal and 2 parts oil meal.

Experiments have taught that the best way to prepare the ration is to cut the oat straw and mix it with ensilage and pulped 
roots, and on this to spread the meal in the manger. The hay is given whole after the mixture is consumed. The quantity of meal given is judged by the milk produced. Very little meal is given immediately after calving and it is gradually increased until, at three or four weeks, a full ration is given. If a cow responds freely to feeding, she is fed the more liberally, usually up to the point when an increase in meal does not appear to induce a relatively liberal increase in milk flow. One pound of meal for four pounds

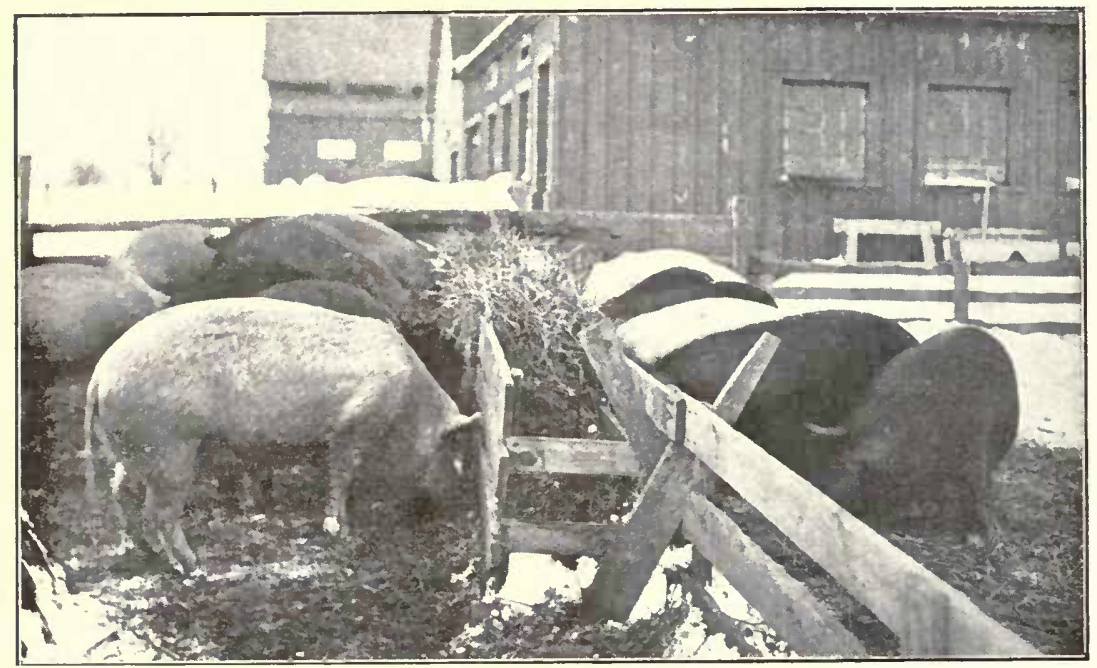

lirood sows feeding on alfalfa hay.

of milk has been found to be liberal feeding. The meals should be varied from time to time in order that they may be taken with relish.

Tests have shown that feeds do not affect the quality of the milk produced so far as per cent of fat is concerned, but may affect the flavour of the milk or the character of the butter. They affect the total quantity of fat produced by influencing the quantity of milk yielded in a given time. Experiments have shown that regularity in hours of milking is of great importance.

SWINE.

As in the case of the dairy cattle, the swine are managed in such a way as to gain the utmost profit from the herd. To this end, only prolific animals of good type are kept, and these are cared for and fed so as to insure the maximum of vigor and thrift. For many years, even during seasons of high prices for feed and of low 
prices for pork, the hogs fed at the Central Farm have yielded a substantial profit. The methods that have brought this about have been learned from experiments, the particulars regarding which are at all times available to persons who apply for them. In view of the difficulty of many in making a profit from feeding pigs, the information gained and given out in bulletins and the Annual Reports of the Farms is of great value to the country.

Only pure-bred swine are kept and many are sold at about two months old at from $\$ 6$ to $\$$ ro per head for breeding purposes,

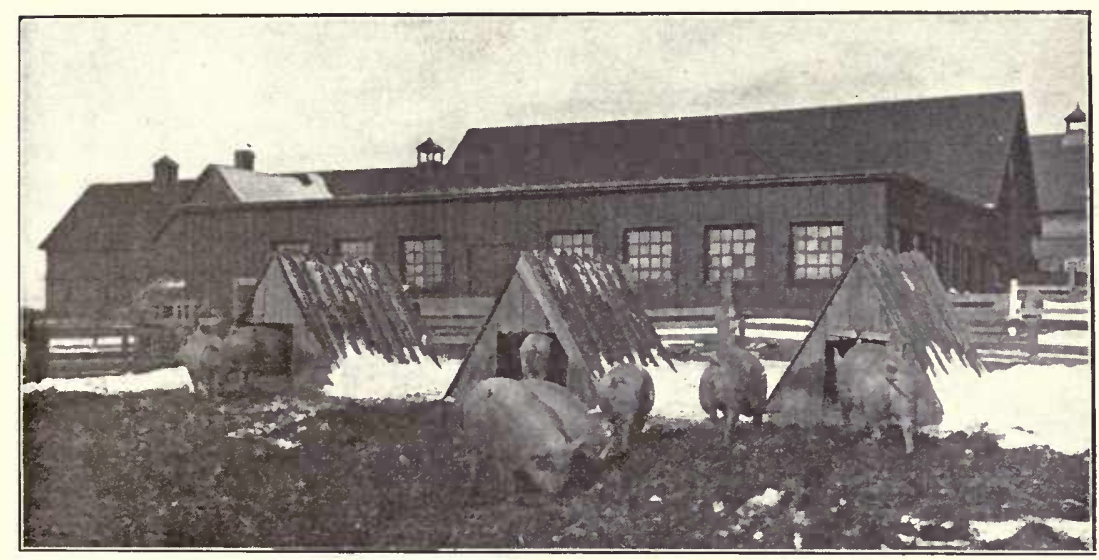

Winter health resort at the Central Farm.

but against the extra revenue these bring, there must be placed a large amount of experimental work that cannot yield much, if any, immediate profit.

Very valuable lessons have been learned in regard to maintaining the breeding stock in a high condition of vigor. A satisfactory method of accomplishing this has been worked out at the Experimental Farm, and more than that, it is done at the minimum of expense. Not only has expensive housing been found unnecessary for the breeding stock of both sexes, but expensive feeding is not only unnecessary but positively harmful.

The breeding stock live out-of-doors practically the whole year round, and feed upon such cheap foods as pasture, roots, soiling crops and clover hay with very little grain food. Of course, when the sows are suckling litters, a richer diet must be given for the benefit of the family, but at other seasons, the food of the sows is of a cheap character.

The only protection given the sows during the winter (and the temperature at Ottawa often reaches $15 \mathrm{deg}$. below zero) is small, 
single-board cabins, and these also provide shade during the summer. The food consists chiefly of roots and clover hay (the latter fed whole in racks) with a small quantity of shorts and bran. Sows under a year old require more grain food to provide for growth. The cost per day when dry from November I to April I, amounted to about + cents per day for mature animals and half a cent more for growing animals that required better feeding. In the early months of the winter, very little grain is fed but towards spring, as farrowing time

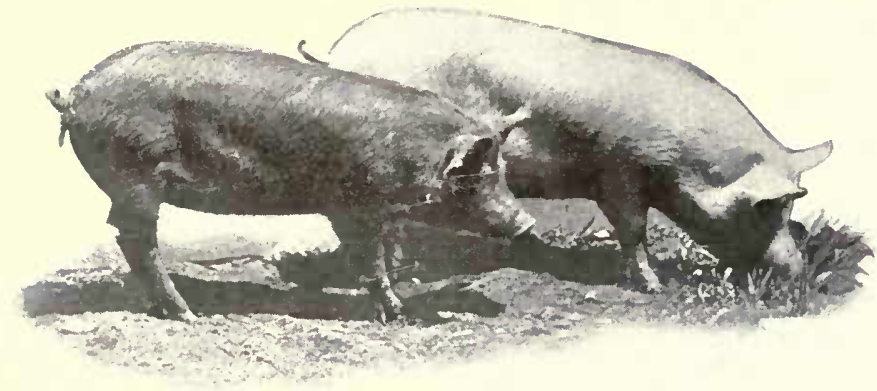

Ideal bacon.

is approaching, it has been found necessary to increase the amount of meal fed. Sows wintered and fed in this way remain active and healthy and almost invariably yield strong litters which they afterwards nourish well.

At the Central, the Brandon and the Indian Head Farms, repeated tests have been made in feeding hogs on wheat that had been frosted. In every case, it was shown that frozen wheat gave excellent results, producing pork at a cost slightly less than 4 cents per pound. The wheat should be finely ground and fed with caution and to very young pigs, in only very limited quantities.

The value of roots for feeding swine was arrived at by comparing them with clover and alfalfa pasture. The roots consisted of mangels, sugar beets and carrots and were pastured by the pigs. In another test, the roots were given to the pigs in pens. Fed in pens on roots the cost per Ioo lbs. of gain was $\$ 4.23$. When meal was added to the roots in the pens, the cost was $\$ 3.09$ per I oo lbs., and when meal was fed to pigs on root pasture the cost was $\$ 3.82$ per roo lbs. On alfalfa pasture the cost of gains was $\$ 3.67$ and on Red Clover pasture, $\$ 3.53$ per I oo lbs. of gain.

The cheapest gains were therefore made when feeding roots and meal in close quarters. Growing pigs to be kept for breeding 
are better for having an outside run, but for fattening, close quarters give the best results when the feeding is such as to maintain good health and thrift.

A comparison of mangels with sugar beets showed that with the former, the cost was $\$ 6.20$ and with the latter $\$ 5.05$ per Ioo lbs. of gain made by pigs eating these foods. A study of foods as they

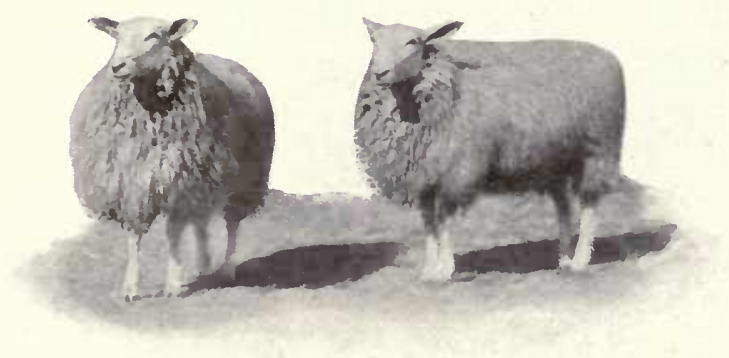

A pair of "Golden Hoofs."

affect quality of pork showed that the best results are obtained from a ration consisting of equal parts by weight of mixed meal, roots and milk.

The points covered here, which are only a mere fraction of the practical lessons that have been learned at the Experimental Farms in the raising of pigs, for the benefit of Canadian stock raisers, serve to indicate the practical and highly useful character of the work accomplished in this branch of the Farms.

\section{FEEDING WORKING HORSES.}

In order to work out the most economical rations and methods of feeding working horses, many foods and systems of feeding have been tested with the teams doing the farm work. A number of fairly definite conclusions have been reached.

It has been found best to give water about fifteen minutes before the grain or hay is fed, and in the evening again about two hours after the grain and coarse fodder have been given. The quantity of food a horse requires depends upon his size and the work he is doing. A very safe rule is one pound of hay and one pound of grain for each 100 pounds that the horse weighs. If very hard work is being performed, the proportion may be changed to three quarters of a pound of hay and one and one quarter pounds of grain for each roo lbs. the horse weighs. It has been found a good plan to give 
a small amount of hay, perhaps one-fifth or one-sixth of the daily ration of hay and one-third of the grain in the morning, and about the same at noon. This leaves a greater quantity of the hay and one-third of the grain for the evening meal.

It has been found of great importance to give no more food at a meal than satisfies the appetite. The preparation of the food consists in mixing in the desired proportion the hay cut and the grain ground. It has been found of some advantage to dampen the feed as this prevents the horse breathing dust and renders the mixing more uniform.

For horses at hard work, clean, well-cured timothy hay is liked best, but very little objection is made to an admixture of clover. Alfalfa hay is highly valuable, more particularly for idle horses which will keep in good flesh upon it, without grain. Corn fodder, grown thicker in a row than for silage, makes good winter feed for idle horses-about equal to average hay. It is economical because so large a yield can be grown on an acre of land.

Experiments were made to find out the cheapest satisfactory grain ration for horses. When barley is cheaper per pound than oats, it may be safely used to occupy one-third of the ration along with two-thirds of oats. A higher percentage of barley has been found to cause digestive and other ailments. When corn is cheaper than oats, it was found advantageous to feed it with oats in the proportion of one-half of each food.

A considerable economy was effected in feeding bran when this food was materially cheaper than oats. The most satisfactory proportion was oats and bran in equal parts by weight. With bran at $\$$ I 5 per ton and oats at $\$ 25$ per ton, the substitution of bran for half of the oats made a saving of from \$IO to \$I 2 per year on the feed of one horse, and the horses were as strong and fit for their work as those fed on oats alone as the grain ration.

Many other experiments have been made with horses at the Experimental Farms, but those related have been selected for their exceedingly practical bearing upon the operation of the average Canadian farm.

\section{VENTILATION.}

For many years, the ventilation of stock barns was under careful experiment. Many recommended and suggested systems were put into operation in horse stables, cattle stables and hog pens, and the results were carefully compared. The object was 
rises and seeks an outlet. The outlet is necessarily at the ceiling and consists of a flue which passes through the roof. At the Experimental Farm, the flues pass through an upper story. These should extend well above the building for the same reason that a chimney must do so in order to draw well.

The inlets enter the stable at the floor level. The inlet pipe is U-shaped and passes beneath the foundation wall. If the fresh air is taken from a covered shed, the mouth outside may be near the ground level and be protected by a grating. If however, the air has to be drawn from outside, more especially in districts subject to snow fall, the pipe should extend 4 or 5 feet above ground and the opening should be roofed so as to avoid the entrance of snow or rain, or undue influence from the wind. The roofed pipe is built against the wall, and the air enters through slots in the sides close against the building. The size of these openings corresponds with the capacity of the pipe inside.

The ventilator works by virtue of the natural tendency of warm air to rise. As the air warms, it becomes foul, rises and escapes by the outlets. As nature abhors a vacuum, the escape of the warm air creates a suction of fresh air by way of the inlet pipes. Since the animals are constantly giving off warmth and expelling carbonic acid gas, the warm, foul air is constantly escaping and cold, fresh air is at the same time entering the stable, thus keeping up a gentle, almost imperceptible, system of ventilation. To regulate the ventilation, a damper is provided in the outlet flue. The closing of this also stops to a large extent the inflow of fresh air, as the draught ceases, stopping the suction. By the original system, the inlet pipe enters at the floor level. This is to facilitate a steady, unobstructed, almost imperceptible flow of air through the stable towards the outlets. To guard against chaff, and dust falling into the opening, Mr. Grisdale, in the main cattle barn at the Farm raised the openings about four inches above the floor level.

The amount of ventilation necessary for a barn depends upon the number of animals to be housed. Sufficient is needed to maintain in cold weather a temperature of from 40 to 45 degrees Fahrenheit. A well-built stable, stocked to a reasonable capacity, should have the air changed every 30 to 45 minutes. Air removed at this rate will carry off the foul air as it is expelled from the stock; it will also remove the vapour, which, if allowed to remain, would condense on the walls and ceilings.

The intake and outlet flues should be about the same in capacity, that is, provided the stable is tightly constructed. Because more 
or less air is sure to enter around windows and doors, the intakes may be slightly smaller than the outlets. At the Experimental Farm, this system is in operation in the main cattle barn in which the milking herds are housed, a bull barn, a barn for fattening cattle, a horse stable and the piggery. The main cattle barn $\mathbf{2} 20$ feet by $5^{0}$ feet accommodates one hundred head. It has three outlets for foul air each 2 feet by 4 feet, and nine inlets for fresh air, each 3 feet by $\mathrm{I} 0$ inches. The fattening barn, Ioo feet by 30 feet, which accommodates $5^{0}$ head of steers, has two outlets, each 2 feet square, and

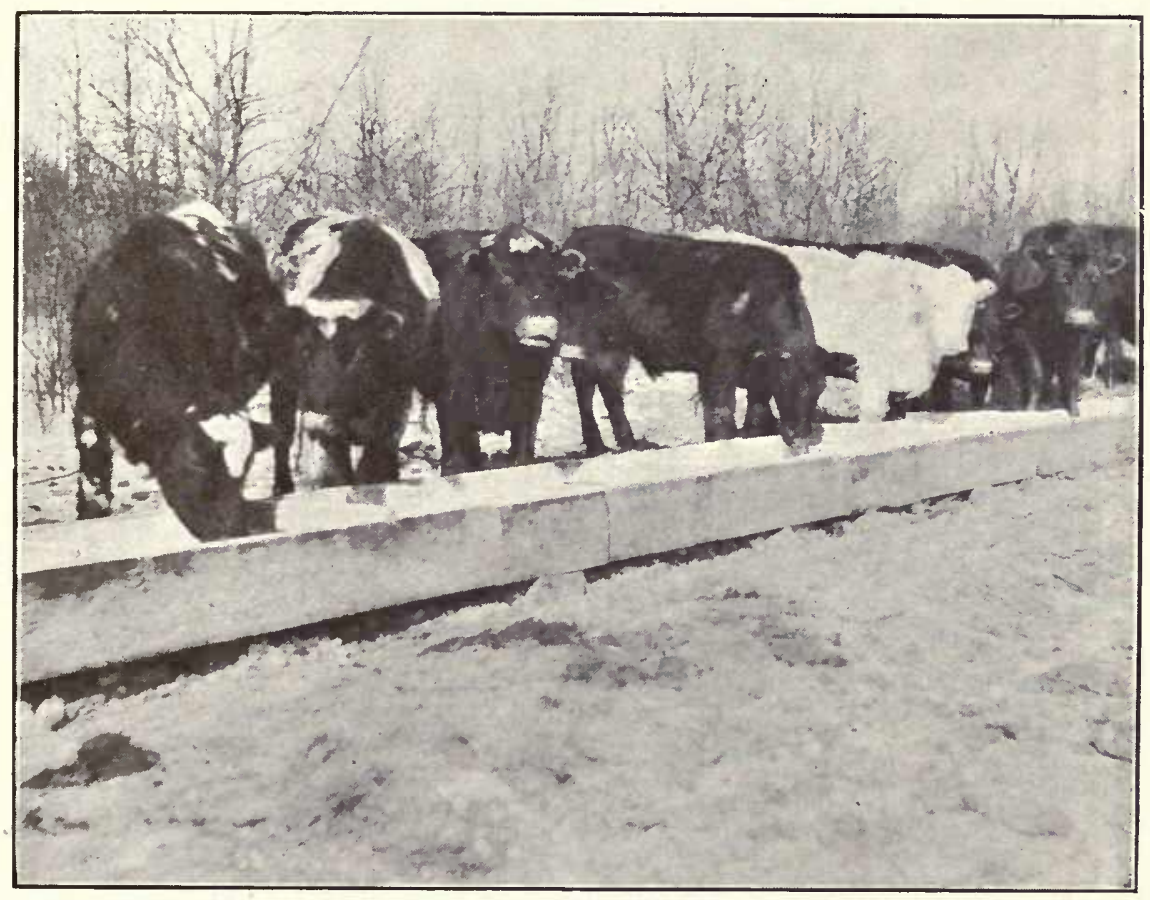

Fattening in the open air at Brandon, Man.

three inlets each 3 feet by 20 inches. The bull barn, Ioo feet by 30 feet, has three outlets about 3 feet square and three inlets about 3 feet by 20 inches. The bull barn outlets, although considered too large, are stated to work satisfactorily under average conditions. The horse barn which accommodates 25 horses, has two outlets, each about 2 feet square and three inlets each about 3 feet by 18 inches. In all these stables the ventilation is good under all conditions of weather. 


\section{HORTICULTURE.}

Long before he became Director of Experimental Farms, Dr. Saunders was intimately associated with horticulture. Both upon his own farm near London and as a Director of the Ontario Fruit Crowers" Association, he took a keen, practical interest in the fruit industry. His knowledge of botany and entomology, as well as horticulture, made him a leader in this work, and so when the larger field opened to him, he was well prepared to enter upon it in a broad and eifective way.

Ip to the time the Farms were established, little experimental work in fruit growing had been undertaken in Canada, except by enthuriastic individuals scattered here and there throughout the Dominion. It is true an experimental orchard had been set at the Ontario Agricultural College, but previous to 1887 , little information had been published regarding the work there.

The need of systematic experimental work in horticulture was keenly felt at that time as the fruit industry was developing very rapidly, and with this development insect pests and fungous diseases were increasing also, and experiments were very necessary to find the most economical way of controlling them. While varieties of fruits had been discussed at fruit growers' meetings for years, no permanent experimental station had been established for the testing of old and new varieties, except at Guelph, and the experience of the individual grower with, of necessity, a limited area for experimental purposes, had mainly to be taken as a rule in the planting of orchards. The origination of new varieties more suitable to the climate of Canada, than those which had originated further south, was a line of work which a few horticultural enthusiasts had undertaken with gratifying results, and which offered a field for valuable work at an experiment station.

The work of the Horticultural Division has been supervised by three different officers since 1887 , viz.: Mr. W. W. Hilborn, Horticulturist from I 886 to I 889 , Mr. John Craig, Horticulturist from I 890 to I 897 and $\mathrm{W}$. T. Macoun from I 898 to the present time.

The original area of land in the Horticultural Division at the Central Farm was 40 acres, which has been devoted to experiments with fruits and vegetables. In 1898 the forest belts, comprising about $2 \mathrm{I}$ acres, were added to the Horticultural Division, and in the same year, Mr. Macoun was appointed Curator of the Arboretum and Botanic Garden, as well as Horticulturist. The Arboretum and 
Botanic Garden, comprising 65 acres of land was included in the Horticultural Division, making the total area of land over which the Horticulturist had charge from I898 to I9II about I26 acres. On April I, I9II, the Arboretum and Botanic Garden were placed under the Botanical Division.

\section{APPLES.}

Shortly after the first Dominion Experimental Farms were established experiments were begun, both with large and small fruits, with the object of finding out what varieties, if any, could

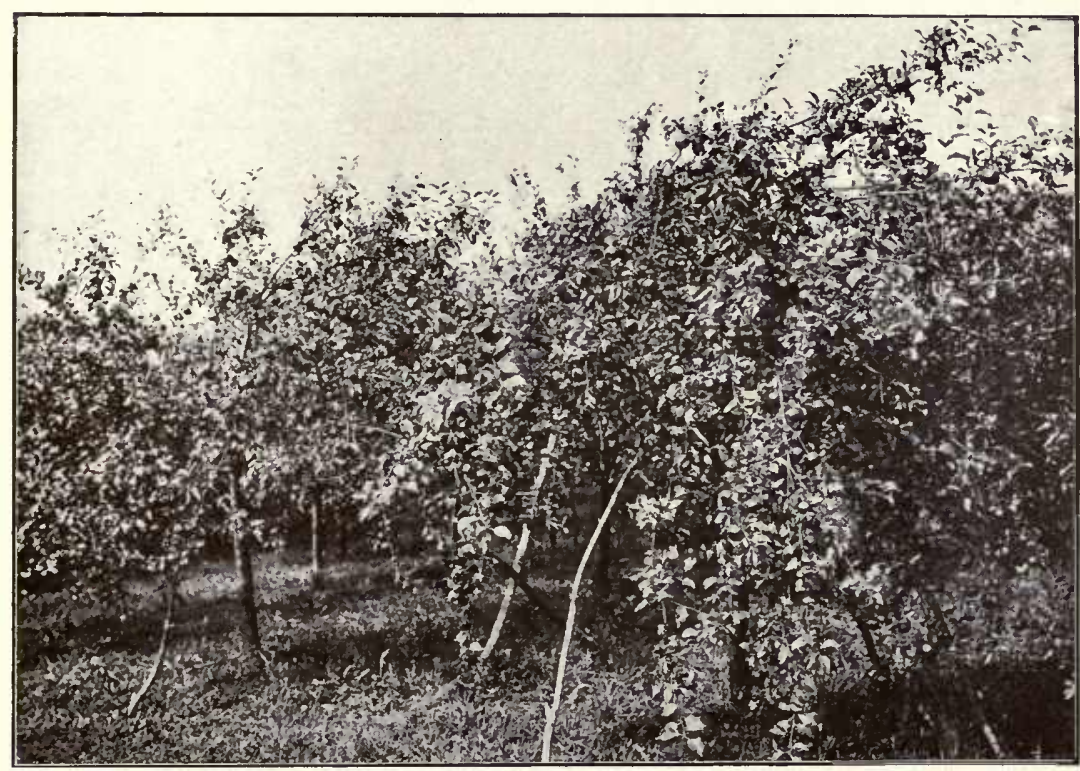

A full crop of Wealthy apples, Central Farm,

be successfully grown, especially in the colder districts of the Northwest Provinces. The apple on account of its relative importance, naturally claimed special attention. During the first eight or ten years more than two hundred of the hardiest sorts of cultivated apple trees obtainable in northern Europe and other northern countries were thoroughly tested, especially at the Experimental Farms at Brandon, Manitoba, and at Indian Head, Saskatchewan. These trees were planted in considerable numbers, often from twenty to fifty trees of a kind, some in shelter more or less dense, others without shelter, but in no case were any fruits produced. New varieties, $32880---4$ 
originated since then, consiclered to be of especial merit and hardiness, have been subjected to similar trials.

In I 887, the year luring which work on the Experimental Farms was begun, seed was obtained from the Imperial Botanic Gardens, St. Petersburg, Russia, of a small, wild, Siberian crab-apple, known as the 'Berried Crab' Pyrus baccata. This crab grows in abundance about the shores of the Baikal Sea and in many parts of Northern Siberia. Young trees were raised from seed of this crab, and as soon

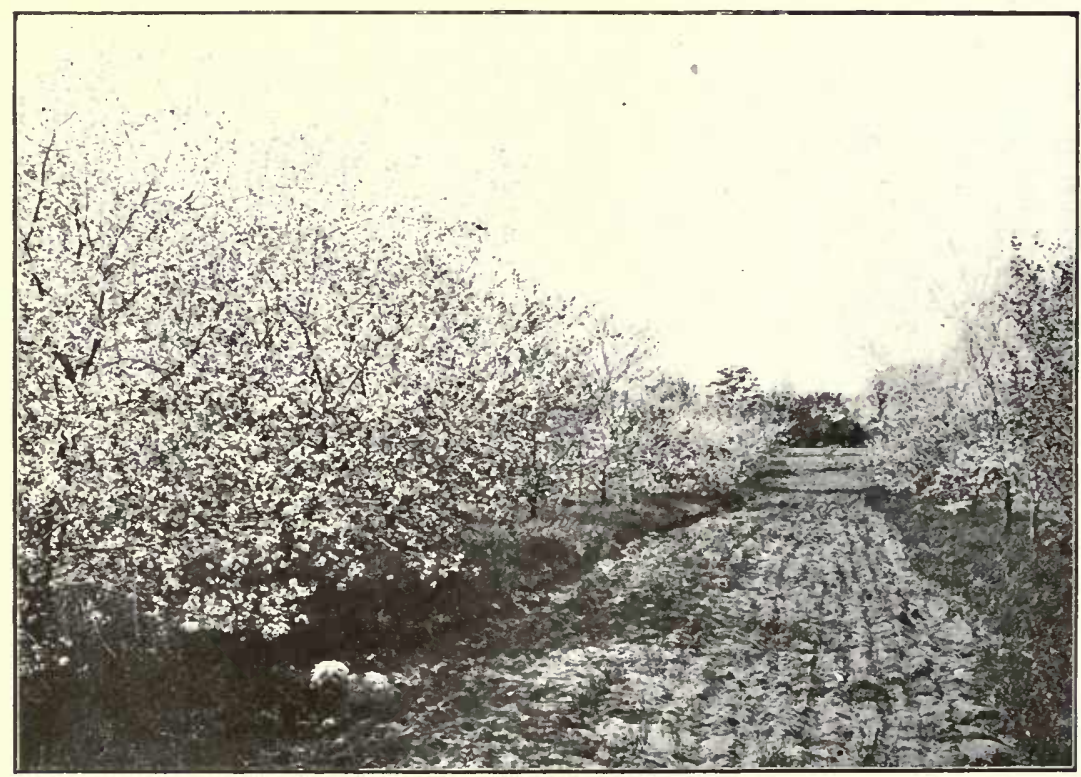

The plum orchard in bloom, Central Farm.

as the specimens were large enough for transplanting, some were sent to Brandon, Manitoba, and others to Indian Head, Sask., and in both places they were found to be entirely hardy. During a trial of about twenty years the Berried Crab has never been injured by winter and the trees have started from the terminal buds on the branches every season. These trees have fruited abundantly for many years, but the fruit of most of them is small, and acid, and in some cases bitter. The trees are rather dwarf in habit, low-branched and strongly built, with the fruit firmly attached to the tree. From its general habit of growth, it is well adapted to resist the high winds to which trees are often exposed in the northern prairies. After four or five years' experience had thoroughly established the character of the 'Berried Crab' for extreme hardiness, efforts were made 
to improve the size and quality of the fruit by cross fertilizing the flowers of Pyrus baccata with pollen from many of the hardiest and best sorts of apples grown in Ontario. This work was begun in I 894, and has since been continued along several different lines. The seeds obtained from the first crosses were sown in the autumn of that year and germinated in the following spring, producing in all about 160 young trees. They were planted in the spring of 1896 when many grew rapidly and soon became shapely specimens. These and other young trees, resulting from similar subsequent experiments have been planted from year to year in orchards at Ottawa, Brandon, Indian Head and other northwestern stations. In I 899, thirty-six of the cross-bred apples first produced and grown at Ottawa fruited and five of them were of such size and quality as to justify their being propagated for more general test. Since then several hundred more of these cross-bred apples have borne fruit and the number of varieties worthy of extended cultivation has been considerably increased. Rootgrafts of some of the more promising sorts were early made and these have been tested for eight or ten years past, at each of the northwestern Farms and have shown very slight inclination towards tenderness, even when planted in exposed situations. The cross-bred sorts grafted on roots of seedlings of Pyrus baccata have produced trees, which, so far as they have been tried, scem to be quite as hardy as the wild form of baccata. There seems every reason to expect that they will prove generally hardy throughout the western country.

There are now growing and doing well at the Central Farm more than four hundred second cross apple trees, consisting of nearly fifty varieties, many of which it is expected will prove of good quality and hardy in the Prairie Provinces and in Northern Ontario and Northern Quebec. A number of these have now fruited, and while the majority bear little, if any, larger fruit than the female parent, a few are considerably larger. Martin, which is a cross between Pioneer and Ontario, is $I \frac{7}{8}$ inches by $2 \frac{1}{4}$ inches in size, and there are others not named which are about as large. Most of these crosses still retain the long, slender stems, the thin tender skin, and the crisp breaking flesh which are characteristic of this crab-apple. The production of the new seedlings has received much attention at the Central Farm which on account of its location is admirably adapted to the process of elimination of tender sorts.

Persons who have originated seedlings were invited to send specimens of the fruit for examination and if a variety was thought promising, scions were asked for. By this means a collection of 83 varie$32880-4 \frac{1}{2}$ 
ties of very promising seedlings has been made. In I 890 , there were 3,000 seedlings raised from apple seed imported from north of Riga, Russia, planted at Ottawa. These have been gradually reduced, by cutting out the poorer ones and by blight and winter killing. Of those remaining there are a few which may prove superior to some named rarieties of the same season, and a large proportion of them are equal to the named Russian apples which have been introduced. Twenty five of these Russian scedlings have been sent to Manitoba and the Northwest for test as they are very hardy.

A new lot of seedlings is beginning to fruit from which it is hoped that something good will be obtained. A hardy, productive red winter

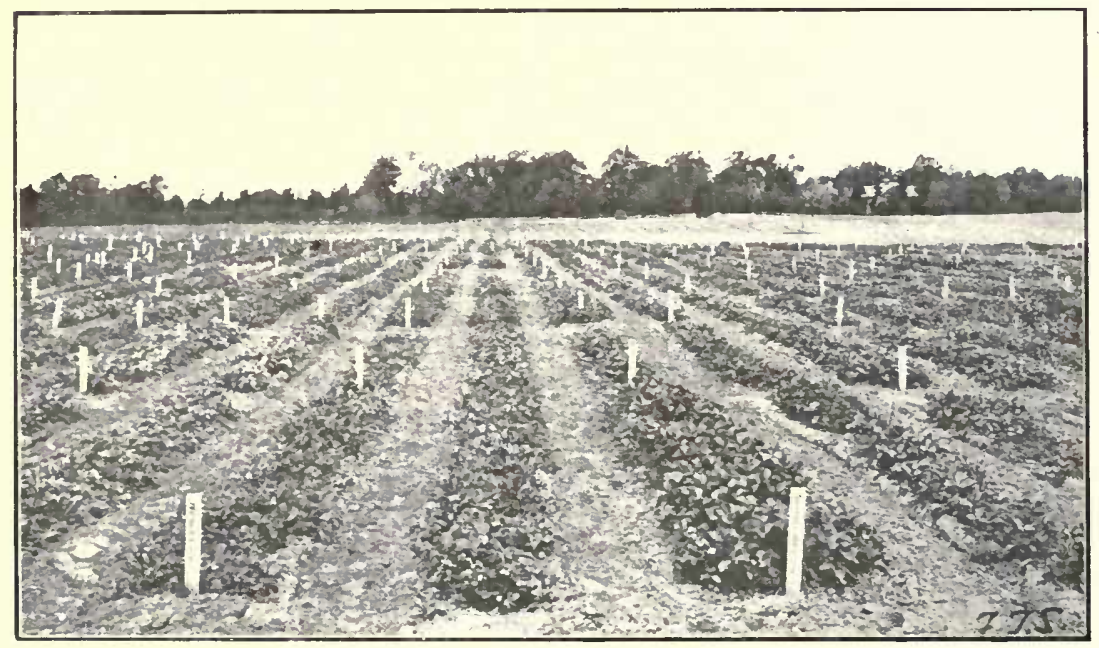

Strawberry experiments at the Central Farm.

apple of the best dessert quality would be a great acquisition in Eastern Ontario, the Province of Quebec and other colder parts of Canada, and in planting these seedlings it was thought the chances were good of obtaining a few superior varieties. Seed was saved of some of the hardiest and best autumn, early winter and winter apples fruiting at the Central Experimental Farm, including St. Lawrence, Wealthy, McIntosh, Northern Spy, American Golden Russet, Winter St. Lawrence, Shiawassee, Fameuse, Swaysie, Scott Winter, Gano, Salome Edgehill. The first planting of these seedlings was done in I90I and the number has gradually been increased until there are I,969 trees now growing. 
The good results which it was hoped to obtain by planting seedlings from fruit from trees which must have received pollen from a great many varieties has been abundantly borne out by the actual results. During the past eight years 997 , or practically $\mathrm{I}, 000$, of these seedling varieties have fruited. Of $58 \mathrm{I}$ of these of which detailed descriptions had been made previous to $1912,78 \frac{1}{2}$ per cent were of marketable size, and only 5 per cent were small or crab-like. Of the 997 varieties, over 200 have been considered so promising that they are being propagated for further test and between 50 and 60 of the best have been named.

The growing and thorough testing of seedlings takes time and the Horticulturist has been very careful not to recommend a new variety until it has been tested and thought to be superior to some other variety of the same season already on the market. Hence the seedlings so far recommended have been very few in number.

\section{OTHER PROBLEMS.}

Many other problems in apple culture have been taken up and dealt with. A record is kept of how much fruit each tree bears at the Central Farm and it has been found that there are marked differences, some yielding about twice as much as others. Propagation of these is being carried on to see if the characteristic fruitfulness will be transmitted. Both fall and spring planting have been tried at Ottawa, the latter method proving the better; this holds true in other parts where the winters are long and severe.

While root-killing of apple trees occurs only at long intervals in most parts of Canada, it is well to guard against it, as fine trees which have reached a bearing age may thus be destroyed in one winter when there is little or no snow; hence, the ground should be covered with something which will hold any snow there may be. This is called a cover crop. These have received much attention in the Horticultural Division.

Cover crops are grown in orchards for the purpose of adding humus to the soil, making it capable of holding more water and also adding plant food to it in some cases. They are also grown with the view of utilizing any plant food not taken up by the fruit trees, thus preventing its leaching. This plant food is returned to the soil the following spring and may be readily used by the fruit that season. The cover crop also takes up and transpires a large amount of water. 
The removal of this from the soil lessens the amount available for the trees, which ripen their wood earlier on this account, ensuring greater safety from winter injury. The seed for cover crops should be sown from the middle of June to the middle of July. Where ripening of wook is more important than conservation of moisture, the early seed. ing is preferable. Many kinds of cover crops have been grown at Ottawa. Among the best are Rel Clover, Summer Vetch, Hairy Vetch, Rape, and Crimson Clover.

Ninety varieties of apples, mainly of the more tender sorts, were top-erafted to learn if this would make them sufficiently hardy to withstand very cold winters, but it was found that it did not do so.

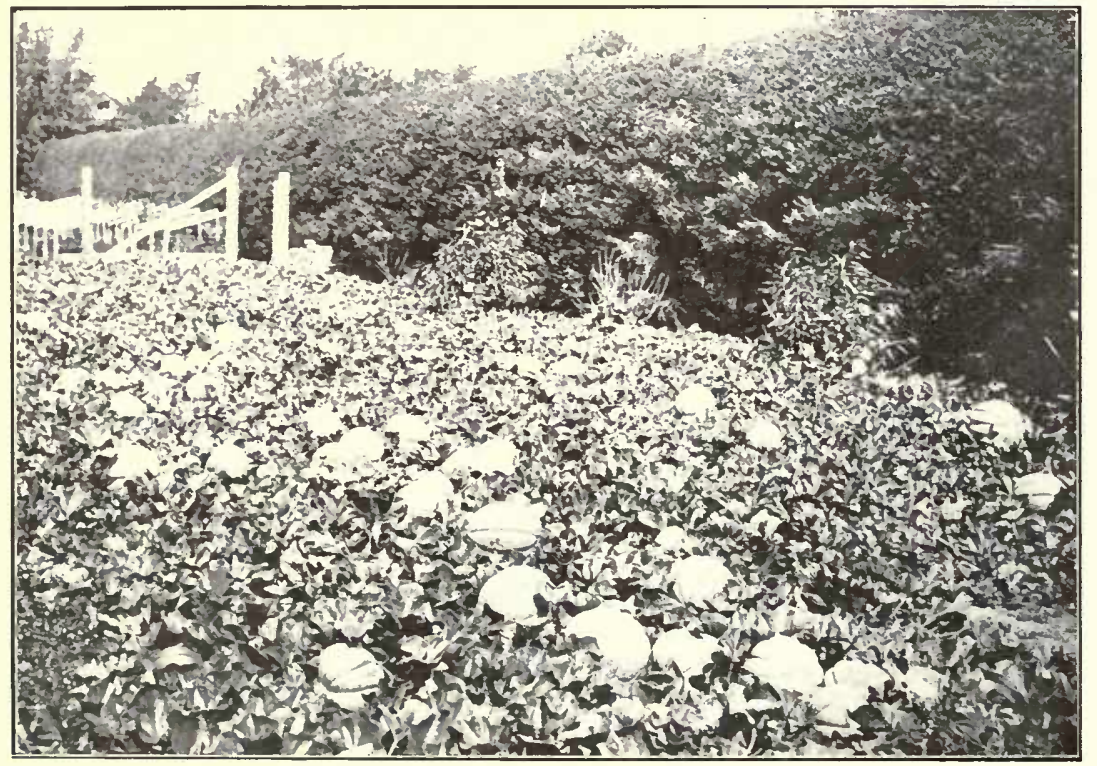

Melon experiment at the Central Farm.

Top-grafting on bearing trees will bring varieties into bearing earlier, however, than if they are grown as standard trees.

The frequent ravages of mice in orchards are easily prevented and measures to this end should not be neglected. The best way is to wrap the trunks of the trees with ordinary white building paper, putting a little soil about the bottom so that the mice will not get at the trunk of the tree near the ground. If this has been forgotten until after snow falls, tramping the snow about the trees will protect them. 
OTHER FRUITS.

Much work has been done with other fruits as plums, pears, cherries, grapes, etc., with a view to discovering by tests the superior kinds suitable for conditions in various parts of Canada. From year to year there are published in the Annual Report varieties of these fruits recommended for the colder sections where it is at all possible to grow these fruits.

Nearly three hundred varieties of plums have been tried at Ottawa and it has been found that the improved American sorts are the best, the European and Japanese being too tender in flower bud. Of pears, the Flemish Beauty appears from tests made to be the safest to plant in the latitude of Ottawa.

Nearly three hundred named varieties of grapes have been tested at the Central Farm and more than one hundred have ripened the same season. It has been found necessary to lay the vines down and to cover them with soil before winter sets in. This is chiefly to protect them against spring frosts. As a rule, the vines are raised at Ottawa during the second week in May, when danger of severe frost is usually over. Good results have been obtained from treating raspberry canes in a similar manner, as then they are well protected by the snow.

\section{VEGETABLES.}

Many experiments have been conducted with a large number of varieties of vegetables, among others the determining of the relative values of varieties from the standpoints of earliness, yield and quality. Potatoes, peas and tomatoes have received more attention, perhaps, than others. Many cultural experiments with potatoes have been tried, including kinds of sets to plant, depth of planting and change of seed. Trial shipments of tomatoes have been made to Great Britain.

An especial feature of the work at present is the development of early and, it is hoped, better strains of vegetables, including peas, corn, beans, melons and tomatoes. 


\section{ARBORIGULTURE.}

Dr. Saunders' accomplishments in the encouragement of the planting of trees and shrubs will live as a monument to his enthusiasm and fine taste in this important branch of work. When people whall have forgotten the benefits he gave to the country in new wheats, hardier fruits and the many valuable lessons on farm practices there will still remain the individuals and plantations of trees and shrubs that he has planted or distributed throughout the Dominion. In the laying out of the Central Farm, sixty-five acres were set apart for the testing of shrubs, trees and plants gathered from all parts of the world. In this area, now hecome a beautiful park, there have been tested under the personal supervision of the late Dr. Fletcher and Mr. W. T. Macoun and the general oversight of Dr. Saunders more than 3,000 sorts. Of these, nearly 2,000 have proved hardy, and for the information of visitors are plainly labelled. The information learned regarding each variety has been carefully catalogued and sent forth for the guidance of the people of Canada.

Dr. Saunders love of natural science for itself, his devotion to the details of all branches of his work and his aesthetic tastes have all combined to bring about most effective results in this work. In the City of Ottawa, the extensive, beautiful driveways and parks made by the Government Improvement Commission is a feature of especial charm and to Dr. Saunders its chief beauty is largely due as he personally selected the trees and shrubs and directed the actual planting year by year. His familiarity with the habits of each and every specimen growing on the arboretum gave him the knowledge necessary for the selection of varieties which would survive and prove most suitable as they developed, in each particular spot to be planted.

\section{TREE PLANTING ON THE PRAIRIES.}

Much valuable work in tree planting has been accomplished in the Prairie Provinces. At each of the Branch Farms as at Ottawa, a large number of species and varieties of trees have been tested and from among them there has been found a greater number of sorts hardy in the west than was expected. The information thus gained has been put into bulletin form and placed at the disposal of settlers and others who when commencing life in these treeless tracts are eager to know what varieties may be safely set out for ornamental and shelter purposes. 
Special attention has been given to the encouraging of tree planting for shelter in Manitoba, Saskatchewan and Alberta. Upwards of one hundred thousand trees have been planted on each of the Experimental Farms at Brandon and Indian Head in shelter belts, avenues and hedges furnishing examples as to the best methods

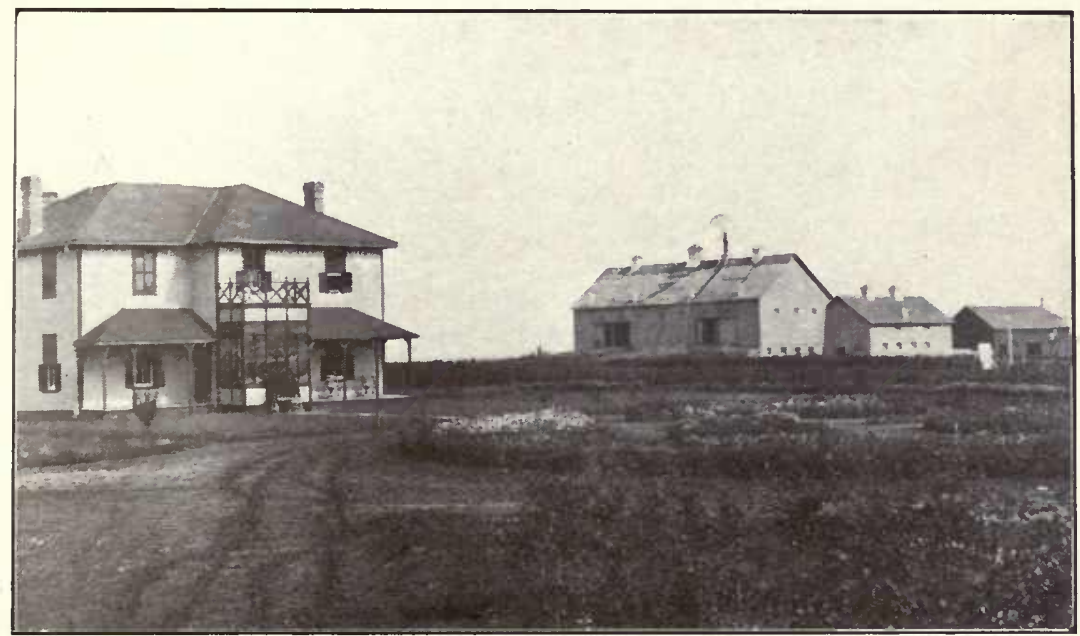

Superintendent's residence and barns, Indian Head, 1893.

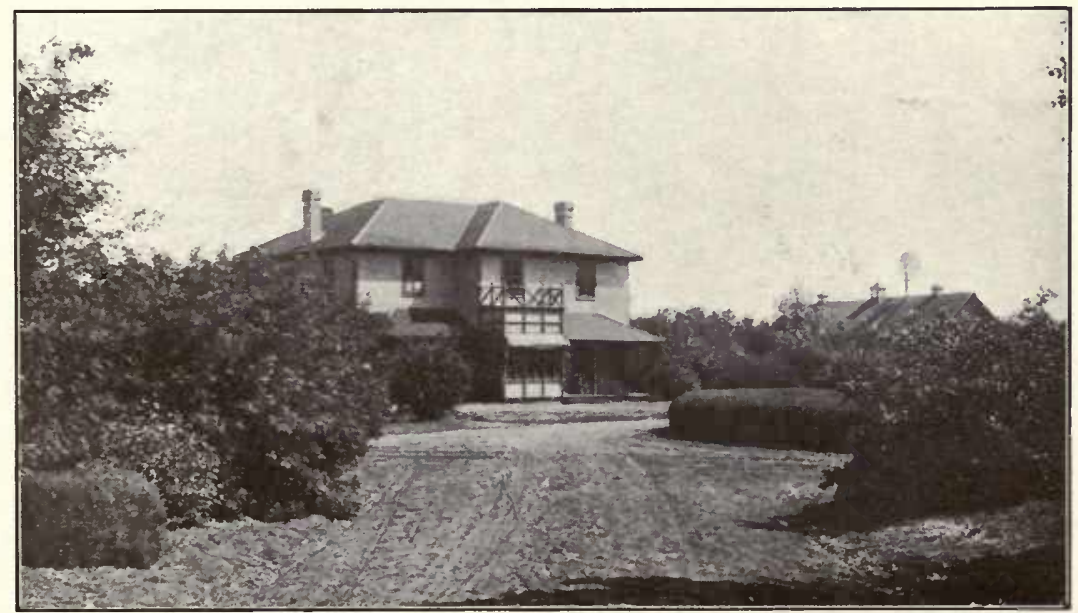

The same view as above in 1909 .

of planting and at the same time giving information as to the cost of such plantations. There has been distributed also from the Farms a vast quantity of young forest trees and also many tons of tree 
seeds. The results of this work are everywhere apparent. Open plains have been converted into sheltered homes for the protection of vegetable and fruit gardens and the comfort of live stock. Through this feature of Dr. Saunders' work the dwellings of the settlers are

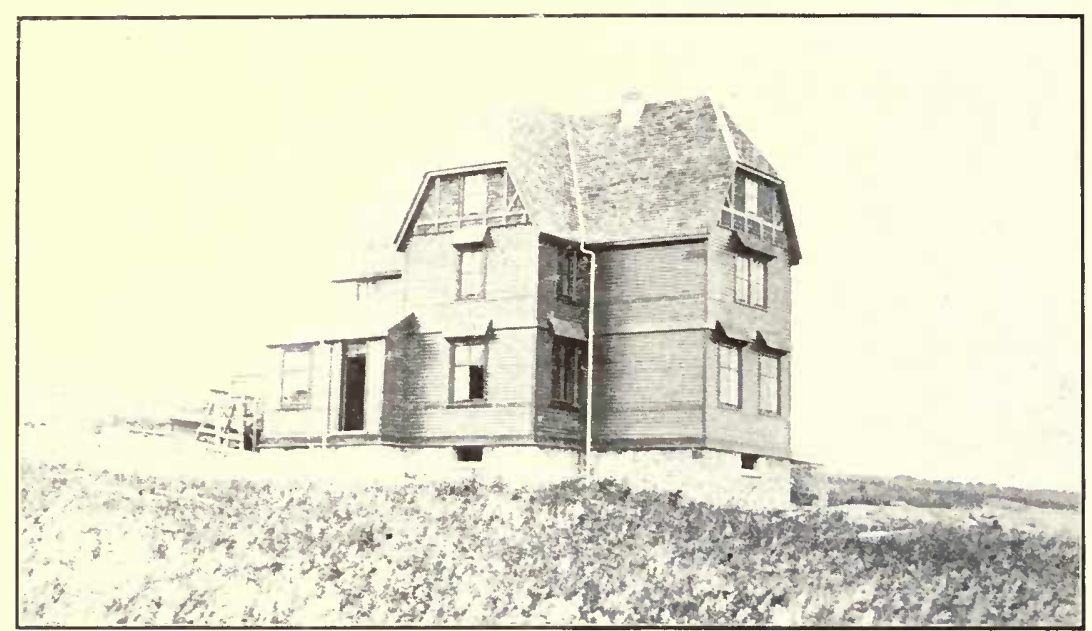

The Superintendent's residence at Brandon, before planting.

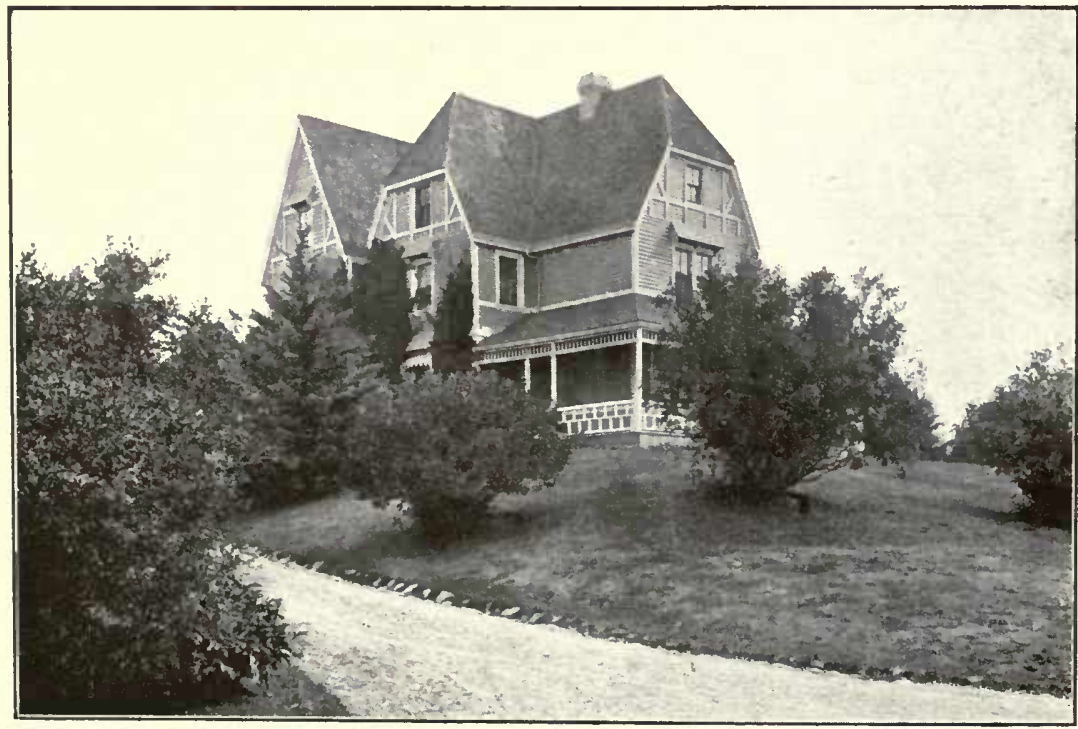

The superintendent's residence at Brandon, 1908.

made more attractive, bare and uninviting surroundings being converted into pleasant places in which to live and pursue the duties of devoted rural citizenship. 
To provide shelter and to add to the attractiveness of the Central Experimental Farm, as well as to afford information as to the rate of growth in the climate of Ottawa of the different sorts of useful timber trees, large belts of young trees were years ago planted along

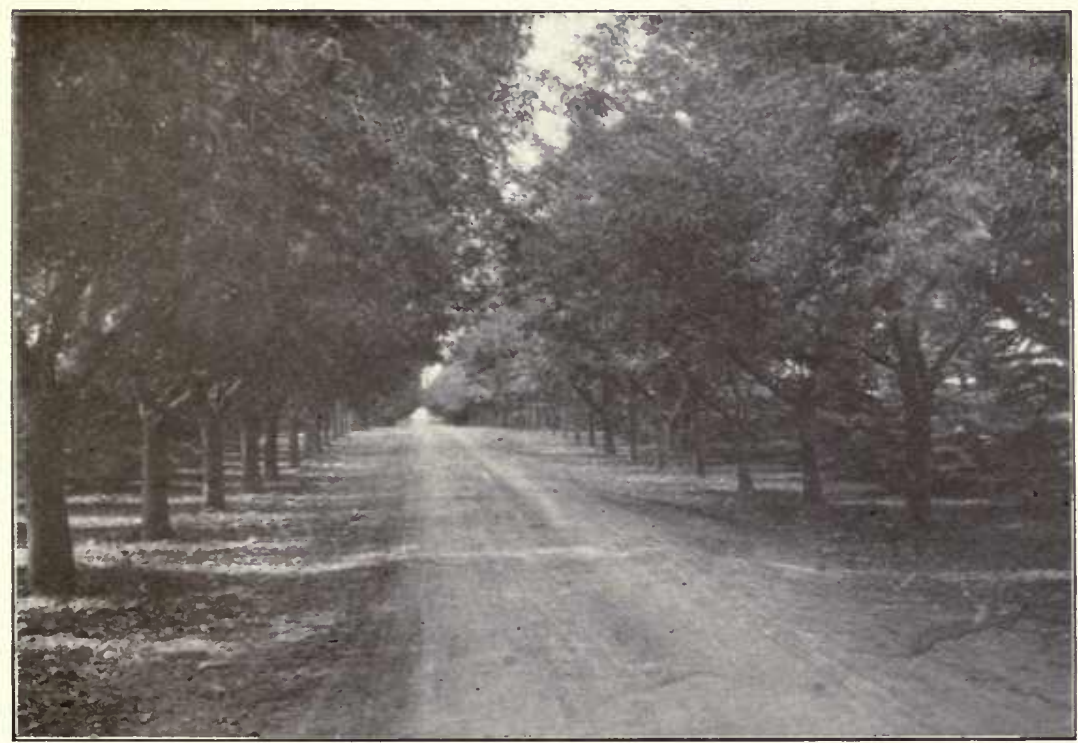

An avenue of Manitoba maple at Brandon, Manitoba.

the Western and Northern boundaries of the Farm. The trees are in blocks of single species and in mixed plantations and embrace about 23,000 specimens.

The first planting was done in I 888. Measurements are taken every year of the growth and height of certain average trees, and tables showing these have been published from time to time in the reports of the Horticulturist.

1. Until the last few years the trees in the mixed plantations were making the most satisfactory growth, and are still making better growth than some of the trees in clumps of single species, but the rapid growing kinds are developing so fast in the mixed belt that they are overshading some of the more valuable trees, and those that cannot endure shade are being killed. To some extent this overshading is prevented by clearing the side branches and letting in more light, and by heading back some of the trees of less value. In nature the proper proportion of rapid and slow growing, shadeenduring and light-needing trees is gradually adjusted as the trees develop, but in artificial planting it is very difficult to arrange them 
in proper proportion, especially when a large number of species are used. The fewer kinds that are used the easier it is to plant the trees in the best proportion of each kind of tree.

In some of the clumps of single species the disadvantage of not having two or more kinds mixed is quite as apparent as the disad-

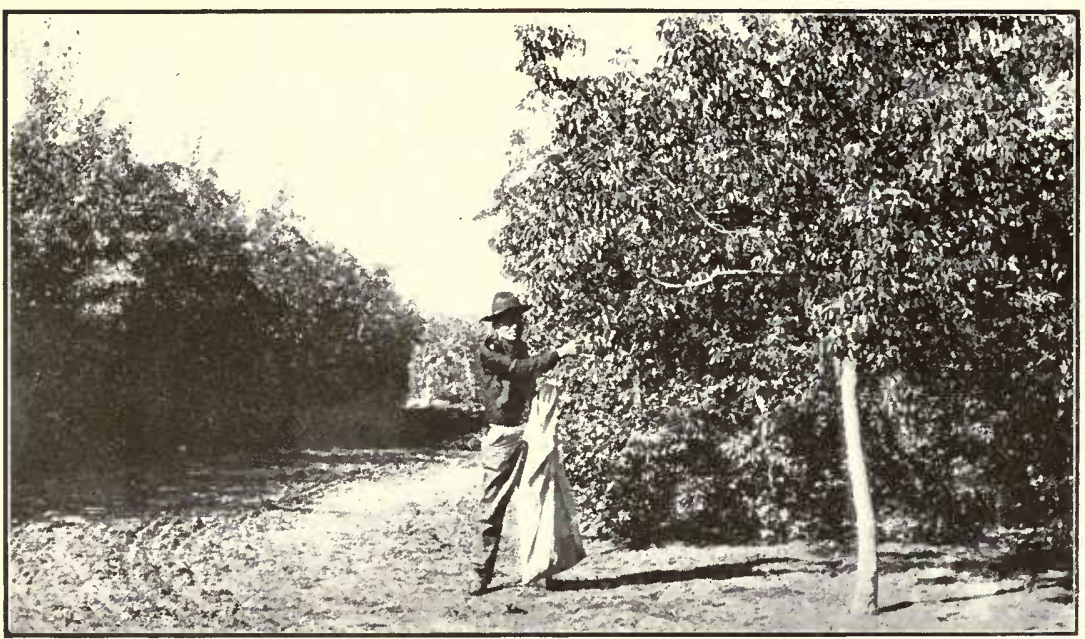

Half breed collecting seeds of Manitoba maple for distribution among farmers.

vantage of having so many kinds mixed in the mixed belts. Ash, butternut, black walnut, and elm, which have thin foliage, do not kill the sod when young, and the growth on this account is checked. If other heavy foliaged kinds, such as larch, spruce, pine or box elder had been mixed with these the results would almost certainly have been better. 


\section{THE WORK OF THE CHEMICAL DIVISION.}

The relationship which exists between agriculture and chemistry is a very close and intimate one. Whether he understands it or not, the farmer who carries on his operations in the field, the feed lot, or the dairy according to correct methods is putting into practical operation the principles of agricultural chemistry. The requirements of crops and animals, the character and deficiences of soils, the means by which soil fertility may be most economically built up and maintained, the nature and amounts of fertilizing ingredients in manures, the nutritive value of forage crops and feeding stuffs, the composition of dairy products, the constitution and preparation of fungicides and insecticides and many other equally important questions can be answered satisfactorily only through the aid of chemistry.

Dr. Saunders being a chemist by profession very thoroughly understood these facts, so that it was but natural that he should at the organization of the Experimental Farms establish a Chemical Division. At its head was appointed Mr. Frank T. Shutt, who still directs with efficiency this Division of the Farms' work.

Ever since I889, a well equipped chemical laboratory has been in operation at the Central Farm wherein the analytical work of all the Farms has been done. In this institution a very large amount of analytical and research work has been accomplished for farming and farming communities in all parts of Canada. Through this work the Chemist has been kept in close touch with the problems that confront the man on the land, and has thus been enabled to render immediate and direct assistance when scientific aid was required.

A very helpful service has been performed through the medium of correspondence. Inquiries to this Division relate to soils and their treatment; to manures and fertilizers, their composition and use; to the nature of feeding stuffs; to the compositoin of dairy products; to the purity of well waters and to many other materials and subjects related to agriculture.

From year end to year end chemical work is going on in the examinations of samples of materials sent in from all parts of the Dominion for analysis. These include soils, naturally accruing fertilizers, such as mucks, marl, etc., forage plants and feeding stuffs, well waters and others things. 
As far as is practicable, these samples are taken in hand in the order received and are dealt with sufficiently fully to furnish the inquirer with the information he requires.

The chief and most important work of the Division is, however, in carrying out by the aid of chemistry such investigations as may serve to solve those problems in Candian agriculture which more or

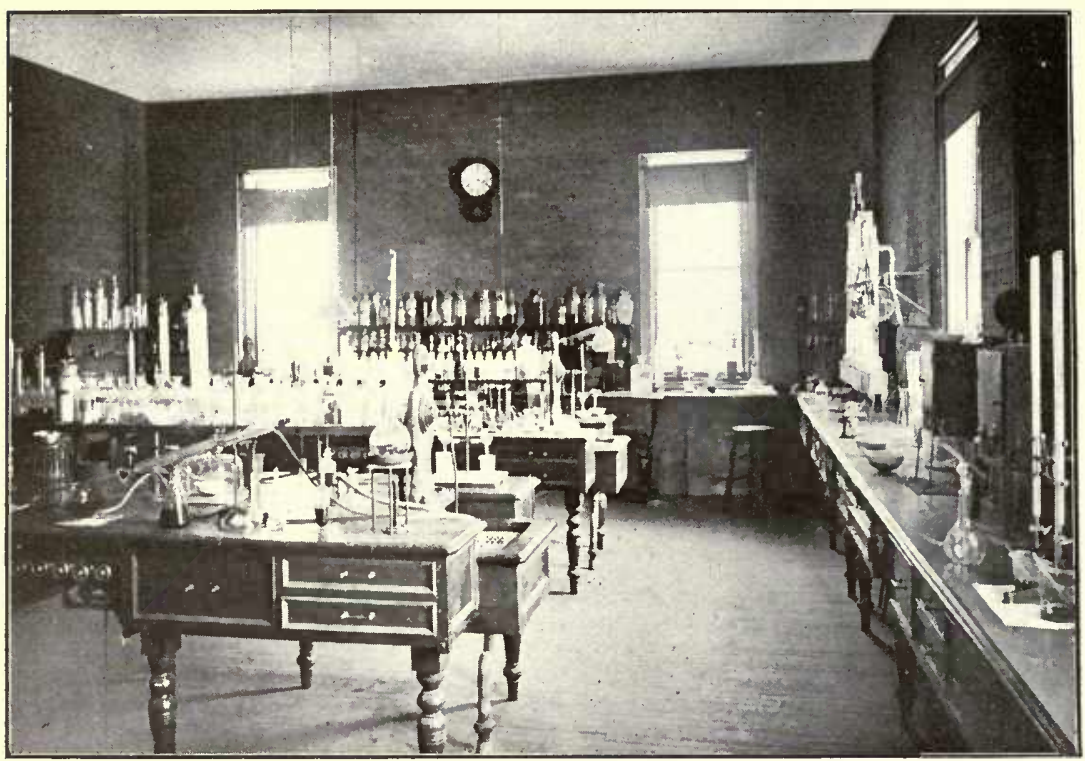

The Chemical Laboratory.

less affect the country in general. These researches embrace a very wide field, which for the purposes of the present review can be only very briefly touched upon.

SOIL ANALYSIS.

A very large amount of work has been done in determiningin so far as the science of chemistry can determine-the productiveness or fertility of Canadian soils. These for the most part have been representative every province of the Dominion having supplied its quota. More particularly, however, are these analyses representative of the larger areas of virgin soil in the Canadian Northwest. The data indicate that excellent soils are to be found in every province of the Dominion.

Many experiments have been conducted to learn the best methods of treating muck soils in order to render them useful to agriculture. 
These have included :-(I) drainage; this has been found an essential of the first importance; (2) the addition of sand and clay, singly and together. Many mucks by this treatment have been converted into excellent loams. (3) the addition of the mineral constituents of plant food-potash, phosphoric acid and lime. These have been applied in the form of potash salts (muriate, etc.), and alkaline phosphates, (basic slag) separately and in admixtures. Wood ashes also have been tried with advantage as well as simple dressings of lime to correct acidity. Most encouraging results in the majority of instances have been obtained from thus applying the lacking mineral elements, and especially from the application of those mixtures which by their alkalinity serve to neutralize the muck's acidity; (4) an application of stable manure for good loam. Although muck is practically organic matter and is rich in nitrogen, it has been found that at the outset (and after the drainage and settling of the muck) such an application has proved very beneficial. This, it is concluded, is due rather to the introduction of desirable soil bacteria than to the small amounts of plant food thus supplied.

ENRICHMENT OF SOILS.

Useful work has been done in conducting experiments for the enrichment of soils through the growth of legumes. For many years a study has been made of leguminous plants in this connection. Reference to the work with clover has already been made under the heading 'Use of Fertilizers,' carried on jointly by Dr. Saunders, Mr. Grisdale and Mr. Shutt. Besides clover, such crops have been dealt with as Alfalfa, Hairy Vetch, Peas, Soya Beans and Horse Beans. In this work, in addition to analysis, the weights per acre were taken of the foliage and of the roots (to a depth of about nine inches) separately, so that the manurial value of the roots could be estimated when the crop was removed. This work also included the analysis of soils before and after the growing of clover. The results indicate that a very large proportion of the nitrogen holding organic matter from the turned under clover becomes part and parcel of the soil, producing wonderful results in the increased yields of succeeding crops.

\section{LEGUMINOUS CULTURES.}

For several years experiments were carried on with cultures or preparations of nitrogen-fixing bacteria using the methods of 
both seed and soil inoculation. In this work, experience and observation have led to the conclusion that inoculation is not so generally necessary as it is claimed by some authorities. Judging from the occurrence of nodules, it is certain that the nitrogenfixing bacteria are by no means restricted to small or isolated areas. In the eastern provinces and in Ontario and British Columbia, at all events, the failures in many instances to obtain a good catch of clover are probably due to deficiency of moisture, poverty in humus,

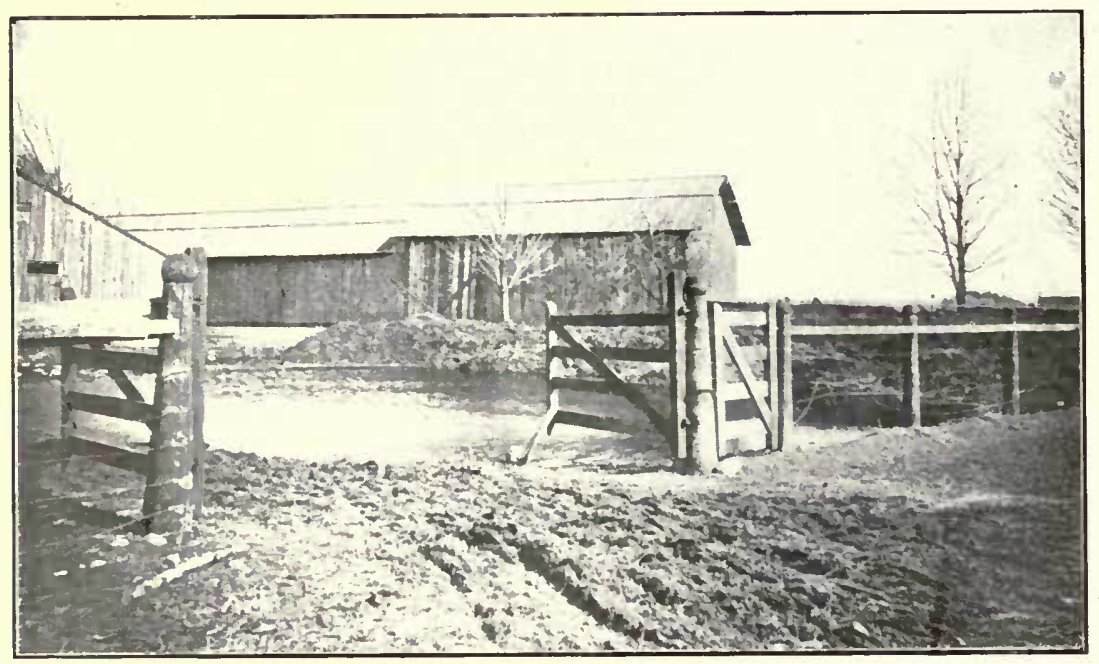

A source of great low on many Canadian farms.

(Through rotting, leaching and drainage more than half of the plant food originally present in manurn never gets back to the soil.)

sourness, insufficient drainage or an unsuitable mechanical condition of the soil rather than to the absence of the nitrogen-fixing bacteria, seems quite probable.

It is, however, quite true that remarkable benefit has followed inoculation for alfalfa at Lacombe, Northern Alberta, and this fact is in itself highly significant, for there are many districts in the Canadian Northwest in which as yet this crop has not been successfully grown.

\section{BARNYARD MANURE.}

Investigation work with barnyard maures has already been briefly referred to. The Chemical Division played a very important part in this undertaking. The losses that ensue from rotting 
under various conditions were accurately determined. Reporting upon it, Mr. Shutt observes that the safest storehouse for manure is the soil, and he unhesitatingly says that the farmer who gets his manure while still fresh into the soil returns to it for the future use of his crops much more plant food than he would if he allowed the manure to accumulate in piles that receive little or no care, and which therefore must waste by excessive fermentation or leaching or both.

\section{FODDER CROPS.}

An exhaustive study by the aid of chemistry has been made of native and introduced grasses with a view to learning their relative feeding value and also at what stage of growth they should be cut in order to yield the best food for stock. In the majority of cases it was brought out that there was a marked deterioration during the later stages of the plant's growth, pointing to the desirability of cutting before the seed approaches the ripened condition. Many native grasses from the prairie were shown to possess highly nutritive properties, and these good qualities remain in the grasses cured naturally on the stem.

Much work extending over several seasons has been done with Indian corn as grown for fodder. A knowledge was gained of the changes in food value that take place at various stages in the plant's growth. The effect of sowing broadcast and in hills and in drills at different rates of seeding was also ascertained. This work has shown the folly of growing varieties that do not reach the glazing stage before frost comes in the autumn, and also in planting so thickly as to interfere with the full development of each individual plant.

In much the same manner the life history of rape, sugar beets and other crops has been followed up, sometimes with the view to tracing the feeding value at various stages of growth; at others, to ascertain the extent to which the crop exhausts the land, which might afford information for a rational treatment of the soil with regard to manures.

\section{NEW WHEATS.}

The Chemical Division has worked hand in hand with the Cereal Division in its investigations towards the development of new improved grains. New cross-bred wheats have been subjected to chemical and physical analyses, with the view of tracing from 
the composition of the wheat the effect of cross-breeding and of environment, and of assisting in the decision as to which hybrids are worthy of perpetuation.

Many other lines of investigation have been carried on with wheats and flours in relation to baking, etc., particulars concerning which are to be found in the reports and special bulletins of the Experimental Farms.

WELL WATERS.

An exceedingly useful branch of work carried on by the Chemical Division has been, and continues to be, the sanitary examination of well waters sent in from all parts of the Dominion for a determination of their purity. More than 2,ooo such samples have been dealt with and reported upon as regards their nature, quality, wholesomeness, etc. This work has enabled the chemist to report that there is probably no better watered country in the world than Canada, both from the standpoint of quantity and purity. It has also impelled him to repeatedly utter a note of warning in regard to the supply frequently furnished to house and farm buildings from wells or springs open to pollution from barnyard or back door surroundings. It is pointed out that shallow wells adjacent to such conditions may remain good for a few years after a homestead is established, but sooner or later, the soil surrounding them must become saturated and clogged with organic filth and unable to perform its useful work of purification. The samples examined from year to year reveal a high percentage of polluted waters and these in 90 per cent of the cases, come from shallow wells situated near polluting sources. What is recommended is the drilled or bored well, located at a safe distance from possible sources of contamination and effectively protected from the entrance of surface wash. Such wells may be depended upon to furnish in the great majority of cases an ample supply of good wholesome water.

\section{MOISTURE CONTENT OF SOILS.}

Work upon the moisture-content of soils managed under various conditions of cultivation has shed much light upon the effect of summer fallowing, packing, surface cultivation, etc. Results at Brandon and Indian Head from work upon fields fallowed and cropped the previous year showed that the land that had been fallowed carried much more moisture all through the season than 
that which had been cropped. The excess ran in many cases from I5O to 300 tons per acre.

The importance of sub-surface packing soils in semi-arid districts has been greatly emphasized in recent years. To determine the actual effect of this process, the Chemical Division carried out a series of tests with soils taken from packed and unpacked areas

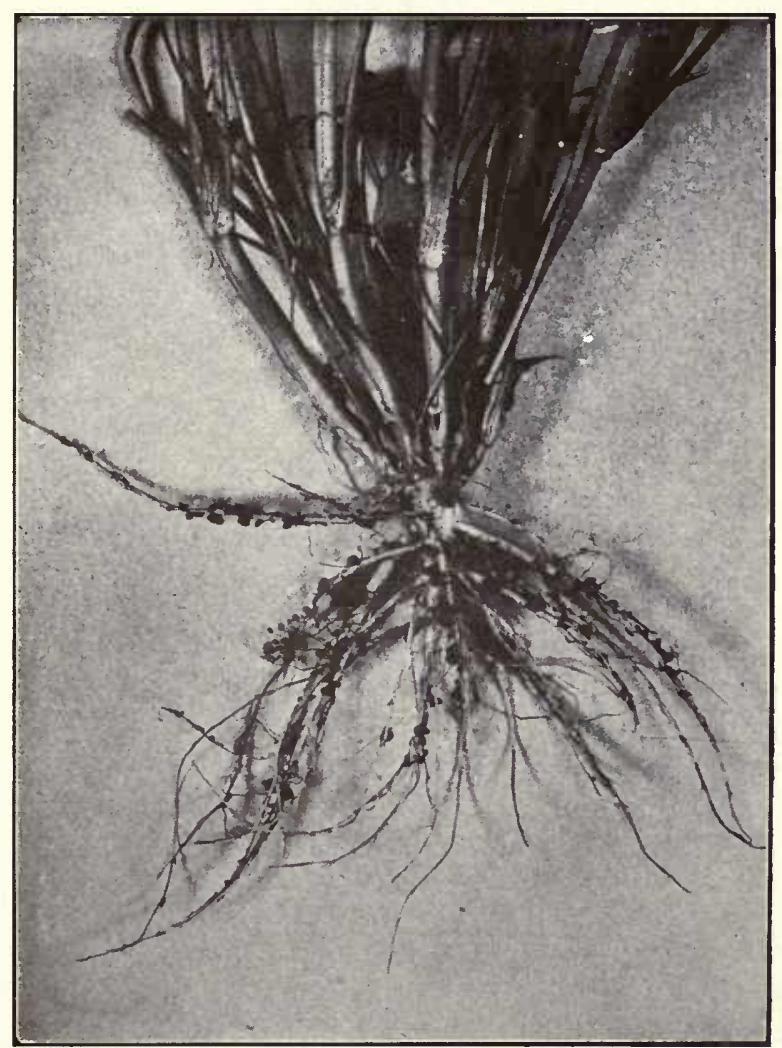

Root of two-year old clover plant. (Note the nodules wherein reside the nitrogen fixing bacteria.

at Lethbridge, Alta. The reported results indicate a slight advantage from the use of the packer.

FACTORS CONDUCIVE TO SOIL FERTILITY.

In the course of a long series of investigations with soils covering both chemical and physical determinations, results were obtained which made it possible to draw certain conclusions regarding what $32880--5 \frac{1}{2}$ 
might be termed fundamental differences existing between fertile, virgin soils and unproductive, worn soils, respecting the factors that go to make up what might be termed fertility, and their relative importance. With regard to these factors, it has been shown that, apart from climatic conditions (temperatures, rainfall, sunshine, etc.), soilproductiveness results from a happy assembling of the chemical constituents of plant food in more or less assimilable forms, of physical properties allowing soil aeration, the retention of moisture, and the providing of freedom for root extension, and, lastly, the presence of an abundance of these microorganisms which, living on the organic matter of the soil, prepare the nourishment of farm crops.

The work in this matter has been particularly in tracing the relation of organic matter and its concomitant nitrogen, to cropproducing power. Very early it was observed that virgin soils of great productiveness were invariably characterized by large percentages of organic matter and nitrogen, and that, on the other hand worn soils resulting from continuous grain growing or other irrational systems of farming, and soils from naturally poor areas, showed meagre amounts of these constituents.

It was found, further, that in soils from humid districts, there was a relationship between the organic matter and the nitrogenthat what affected or destroyed the former dissipated the latter; while on the other hand, the methods that led to the increase of the organic matter also raised the nitrogen content. Undoubtedly these two constituents stand and fall together.

Another feature of importance was that accompanying a fair organic content there was usually a goodly proportion of available phosphoric acid, potash and lime.

Then again it was evident that the proportion of organic matter present influenced in a marked degree the capacity of the soil for holding moisture and in several other important particulars affected the mechanical condition.

It is more than probable that fertility is largely dependent upon the rate of nitrification during the growing season, which, though largely regulated by temperature and moisture, must be materially affected by the amount of the food supply that the microorganisms find in the form of partially decomposed nitrogenous organic matter.

From all this work with soils, the Chemist concludes that the percentage of organic constituents-humus-is directly and indirectly a measure of the soil's fertility, and that this percentage is largely influenced by the treatment the soil received. 
The natural means for replenishing the soil with organic cons tituents is farm manures, but in the districts where such are most required, the supply is frequently inadequate. In accordance with the deductions drawn from the work of the Chemical and other Divisions of the Experimental Farms, the rational plan is to adopt a rotation including the use of leguminosae - the nitrogen-gatherersThese latter are nature's soil enrichers. No other family of plants can be used on the farm possessing the unique and valuable property of appropriating the free nitrogen of the air-nitrogen that may be subsequently made available for succeeding crops. Not that the fertilizing value of the legumes lies simply and solely in the nitrogen they contain, though therein is their chief merit; the large quantity of humus-forming material they furnish, the mineral matterpotash phosphoric acid and lime are features the significance of which may in too many cases be underestimated.

\section{WORK ON DAIRYING.}

The Chemical Division has also rendered aid to the dairying interests of the country, as for instance, is made clear by the following bulletins issued during the past few years: 'The factors that control the water-content of butter'; 'Apparatus for determination of water in butter' and 'The Sweet cream process of butter making'.

SOFT PORK.

Closely associated with the foregoing was the investigation into the character and causes of 'soft pork' a work which was of undoubted value to the upbuilding of the export bacon industry.

To publish even the briefest reference to all the undertakings and accomplishments of the Chemical Division would alone occupy much space. Sufficient has been referred to and briefly described to indicate the character, scope and usefulness of the chemical work. The field has been found wide and varied, and though much has been accomplished, much more remains to be done. 


\section{POULTRY.}

While poultry has been kept at each of the Farms ever since they were established, the chief experimental work has been done at the Central Farm under the immediate supervision of Mr. A. G. Gilbert. At the Branch Farms a number of the most suitable farm breeds have been kept in sufficient numbers to carry on comparative tests of egg production and fattening. Only thoroughly good specimens have been kept and these under good farm conditions.

The reports that have been annually issued have been useful guides to farmers and poultry keepers seeking information on the relative values of breeds and of rations and methods of feeding.

The work with poultry at the Central Farm has been of a much more comprehensive nature. Here practically all of the good utility breeds of chickens have been kept for purposes of experiment in regard to the various phases of the industry, as for example, early maturity, egg production, development of laying strains, vitality of stock. housing, feeding, natural and artificial incubation and brooding, and many other points.

Special emphasis has been placed upon quality and vigor of stock and the development of winter laying strains. In connection with these features, much experimental work has been done in regard to housing which has brought out the value of the airy house ventilated by cotton screens set in the wall. Even in the cold winter climate of Ottawa, these airy poultry houses have been demonstrated to give better results than closely built, warm pens.

By a long series of experiments with trap nests, by which poor layers are discovered and discarded and only good layers retained for breeding, it has been shown to be practicable to build up heavy la: ng strains that when kept in good condition may be depended on to yield a sure and substantial profit.

Repeated tests in hatching with incubators heated by electricity have proved this new system to give excellent results. A 60-egg incubator was heated by the wires used for lighting the poultry house. The requisite uniform temperature of $\mathrm{rO}_{3}$ degrees was easily maintained with the result that hatchings ranging from 75 to 85 per cent of fertile eggs set were obtained. The electric brooder known as an "electrohover" was found to be equally satisfactory.

Systems of feeding and comparative values of different foods have provided an almost exhaustive study. Feeding for egg production, for fattening, for early maturity, for vigor of breeding stock. 
for flavour of eggs, have all received attention, and up to a certain point solved.

Among the most important conclusions arrived at as the result of long and practical experience are the following:-

That variety in rations is absolutely necessary to successful winter egg production, health of the birds, and immunity from the vices of egg-eating and feather-picking;

That germs of eggs in springtime,-under ordinary conditions of poultry keeping,- do not become strong until the fowls have run outside and recovered from their long term of artificial winter life and treatment;

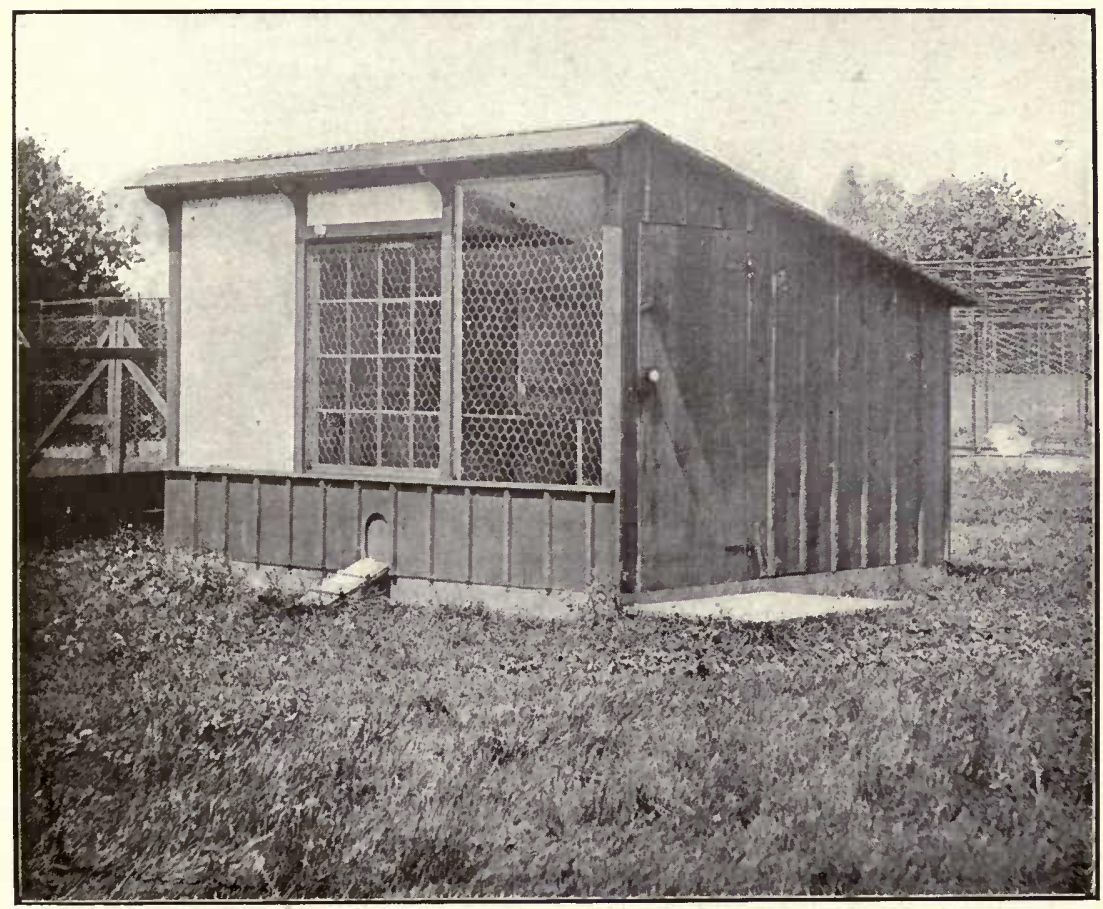

Cotton front colony house.

Two curtains rolled up on mild winter day.

That white diarrhoea etc., is in the great majority of instances in early spring due to the lack of constitutional vitality on the part of the breeding stock. One of the principal causes is given in the preceeding paragraph;

That germs do not-under ordinary conditions-become strong enough to hatch out a satisfactory percentage of chickens until the 12 th or 15 th of April; 
That the most favourable time for farmers to have their chickens hatch out is usually the first week in May. Unless provided with artificial means of hatching and rearing chickens it is not convenient to do so at an earlier late;

That to have the chickens make steady growth it is absolutely necessary after the first forty-eight hours that they should be carefully housed, regularly fed, and kept free from lice;

That if well fed and cared for, up to the saleable age of three and a half, four or five months, the chickens will be in such satisfactory condition that very little, if any, crate-fattening will be required to make them choice market specimens;

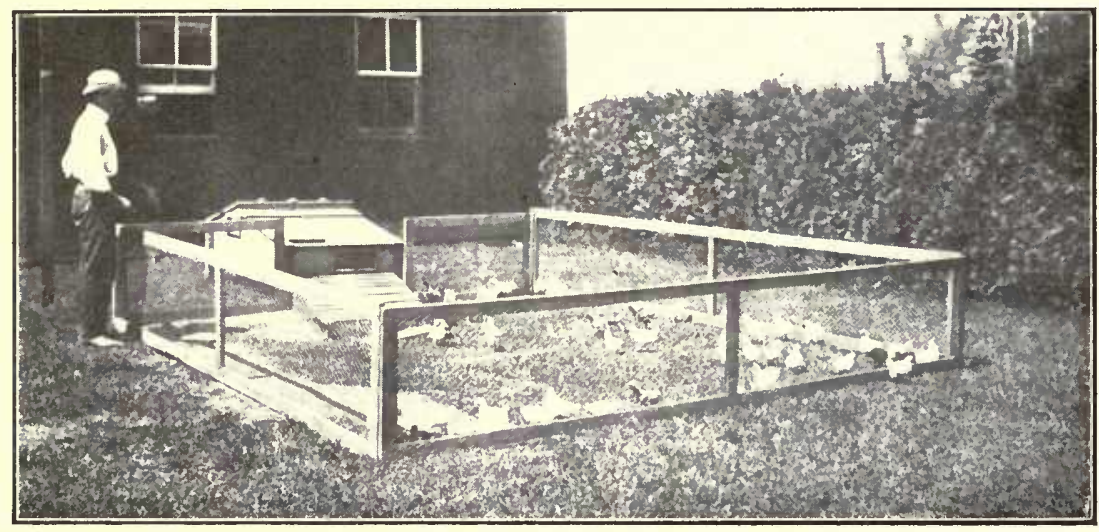

Chicks brooding in the Electrohover.

That a midsummer moult is preferable to a later one and it may be brought about by directions as shown in Bulletin No. 54, which are too lengthy to repeat in this brief summary;

That it is not necessary to have a male bird with the hens in order to have successful winter laying;

That to secure the highest prices for winter eggs they should be of good flavour, the result of clean and generous feeding of varied rations; uniform size; clean in appearance; neatly put up and not fertilized;

That neither correct nor inviting market types, early layers nor perfect specimens as show birds can be produced if the chickens are allowed to 'pick up their own living' in their early days. A chicken which has become stunted from being stinted in its food never recovers from the neglect;

That in artificial incubation it has been found that if the chickens after being hatched are subject to sudden change in temperature, they are apt to become chilled and diarrhoea will follow; 
Experience has emphasized year after year the necessity of the germs of the eggs used for hatching being strong so that they will hatch out in the shape of robust chickens which will make vigourous growth.

The utmost care has been exercised in the recording of results which have been made the subjects of reports, bulletins, leaflets, lectures, newspaper articles and correspondence that have reached a very wide circle of farmers and students of the industry in all parts of the Dominion.

This information has been and is going out almost continuously in the English and French languages free of cost to every one who asks for it. That the work of the Poultry Division has had a marked influence upon the poultry industry of the country is a fact beyond refutation; that backward methods by Canadian poultry raisers who can read the English or French language are inexcusable is a fact equally well established. 


\section{WEEDS AND PLANT PESTS.}

To the extraordinary progress that has been made in Canada in combating insect and weed pests, much credit is due the work of the Botanical and Entomological Divisions of the Experimental Farms system. Himself an authority upon the sciences that underlie the understanding of these enemies of crops and a keen judge of men, Dr. Saunders was able to make a wise choice in the selection of the late Dr. James Fletcher, to take charge of this Branch of the Farms' work.

Through his entire official career, Dr. Fletcher was constantly on the alert for information through the press, correspondence, public meetings and personal observation, regarding the introduction and ravages of insect enemies and the appearance of weeds of every kind. The pests of other countries were made the objects of study so as to be able to identify and combat them effectively, should they appear within the borders of the Dominion. Collections were being continuously made from material collected in the field, the forest and the orchard and garden, as well as through the kindness of correspondents who applied to the Division for help in their studies of insects and of plants.

Much time was given to the rearing of insects, eggs or larvæ. In this way, an exact knowledge was gained of the preparatory stages of insects, the number of broods and the times of year at which they develop, so as to better devise remedies for injurious species. The information thus gathered was systematically recorded, so that, as time went on a vast fund of most valuable data was accumulated for the benefit of the farmers of the country.

Equally extensive and complete was the work with plant life. Constant additions were being made to the herbarium from specimens sent in by correspondents for naming, or from donations, and in many instances, fine specimens of rare plants have been acquired by growing the plant from the seed and securing samples at different stages of development. By this constant study and systematic accumulation, the Botanical Division became a museum of the weeds of Canada, of extraordinary completeness, and in his capacity, of Dominion Entomologist, Dr. Fletcher was an authority of the highest order, who was ever being appealed to from all quarters of the Dominion.

Through the press, the public platform, and by bulletins and reports, the information gathered was being constantly given out until the great majority of the farmers, who have studied their calling, are able to identify the various pests and apply an effective remedy. 
In going through the reports of the Farms and the files of agricultural newspapers, we can readily discover from writings of Dr. Fletcher and Dr. Saunders, the introduction and prevalence at certain periods and in various districts of injurious pests. In almost every case the descriptions given made identification comparatively easy. Remedies recommended were so practical and clearly described as to be readily applied. Many will recall the recommendations of the 'Hopper Doser' and the 'Criddle Mixture' for grass-hoppers, and the advice to avoid sowing weevil-infested peas. The wire worm, the cut worm, the Hessian fly, the grain aphis, the wheat midge, the corn worm, the army worm, the San José scale, the horn fly and scores of other pests have been dealt with from time to time.

The Experimental Farms being deeply concerned with forest trees as well as with field and garden crops, much attention was paid to insects attacking sylvan growth. Consequently, attention was directed to visitations of such insects as the Tussock Moth, the Forest Tent Caterpillar, the Gall Louse and other enemies of forest and shade trees and, in every case that a remedy was feasible, it was given out so clearly and so fully that none need misunderstand.

In November of 1908 the Experimental Farms, and in fact the whole country, suffered a severe loss in the death of Dr. Fletcher. By this time the work had become very heavy and in order to cope with it at all successfully the following year the joint Entomological and Botanical Division was divided into two separate Divisions and a Dominion Entomologist (Dr. C. Gordon Hewitt) and a Dominion Botanist (Mr. H. T. Gussow) were appointed each to have charge of his special subject.

\section{THE DIVISION OF ENTOMOLOGY.}

The Domion Entomologist has, as an important part of his work, the administration of the 'Destructive Insect and Pest Act,' which was passed in I9Io to prevent the introduction and spread of insect pests and diseases injurious to vegetation. In order to prevent the introduction of insect pests from other countries, the regulations under this Act require that trees, shrubs and other nursery stock shall be imported only during certain specified periods of the year and through certain ports, of which there are nine from Halifax, N.S., to Vancouver, B.C. At six of these ports, fumigation stations are established, where certain classes of trees and plants are fumigated, in houses provided for the purpose, with hydrocyanic acid gas to prevent the introduction of the San José and other scale insects. 
In addition to this precaution, trees and plants from certain countries are inspected by officers of the Division, either at the port of entry or at the destination of the shipment.

The powers which the Act gives to eradicate pests which have already been introduced into Canada are being used in Nova Scotia and New Brunswick, where an active campaign is being carried on by the Division against the Brown-tail moth, which has recently spread into these provinces from the New England states.

In addition to the work of inspecting and fumigating imported trees and plants and the Brown-tail moth control work, the Division

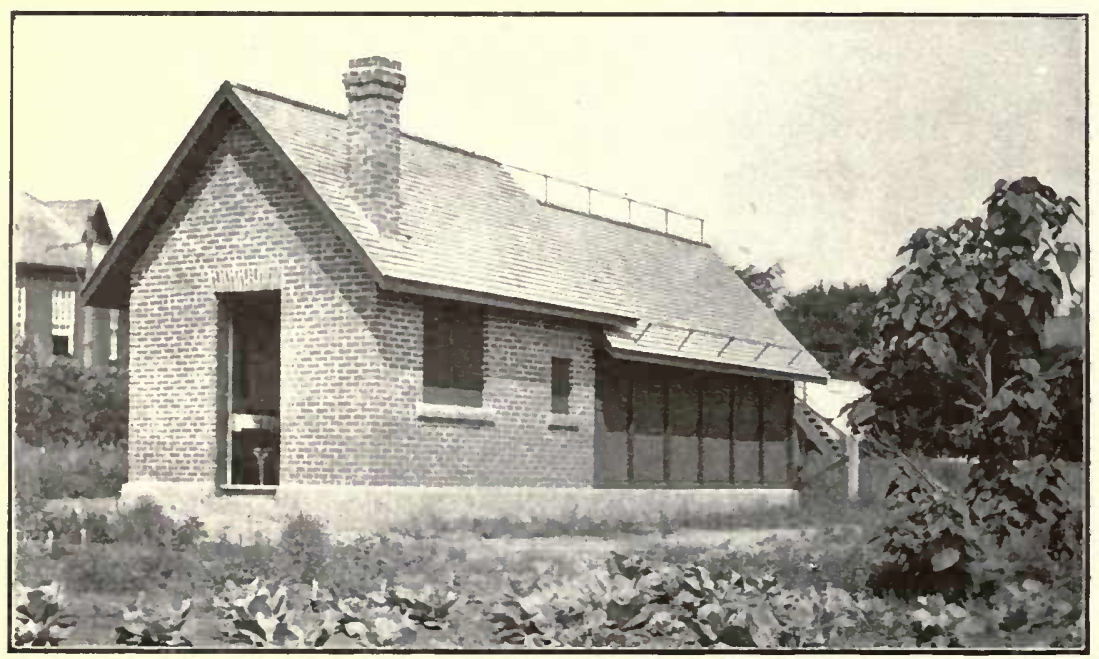

The open-air insectary, Experimental grounds at Ottawa.

of Entomology also carries on many other lines of work. These include the study of insects and the means of control both natural and artificial. As insects are intimately related to agriculture, horticulture which includes fruit growing, forestry, public health and other activities of man, the extensive field such studies cover will be understood. The importance of this work is indicated in the annual toll levied on the farm crops of Canada by insects which is estimated to be at least fifty million dollars. To this must be added at least forty million dollars of an annual loss to the fruit crops of the Dominion from insect injuries besides enormous and inestimable losses from similar causes that have to be borne by the timbered areas of the country.

In the carrying on of its work the Division of Entomology co-operates with other branches of the Government service and 
provincial Departments of Agriculture that are likewise concerned with the protection of field crops, forests and orchards.

In order to cope with the varying conditions and habits of insects over so vast an area as the Dominion, field stations or laboratories are being established. Six such stations have already been established and are located.in Nova Scotia, New Brunswick, Quebec and British Columbia and two in Ontario. Plans are under way

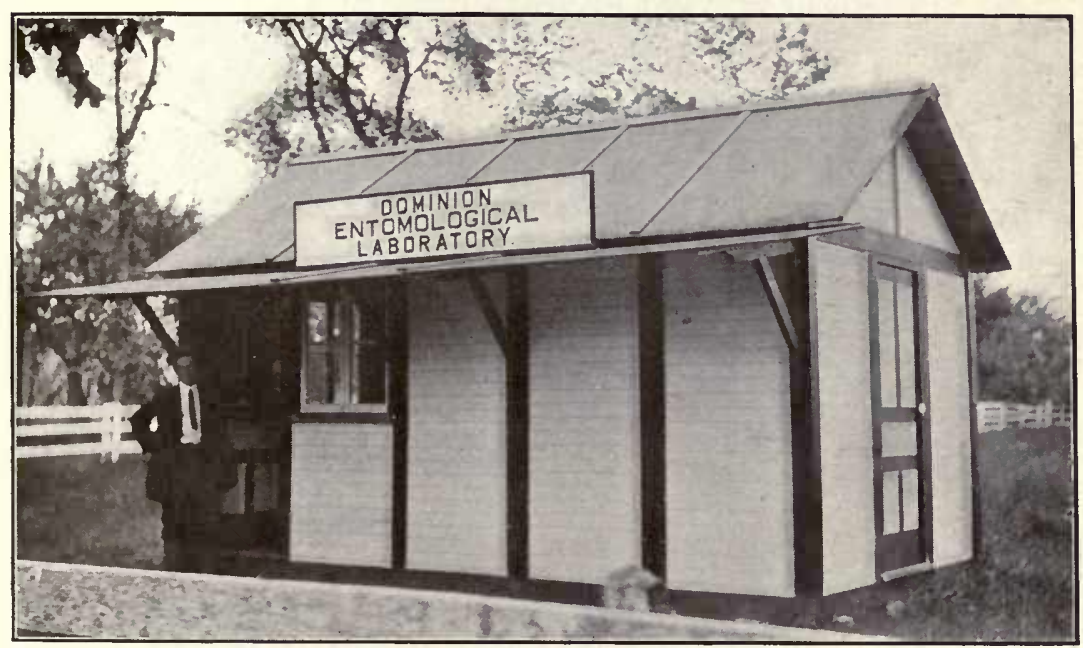

Station at Bridgetown, N.S.

One of the Entomological field laboratories established in several provinees for the investigation of local problems.

for establishing one or two field stations in the Prairie Provinces for the study of insects injurious to cereals.

An apiary is maintained in connection with the Division for experimental purposes and large numbers of inquiries are received relating to bee-keeping and especially to the treatment and .prevention of bee diseases which are spreading to a serious extent in Eastern Canada. Special attention is being given to the breeding of bees with a view to obtaining varieties most suitable to Canada and most resistant to disease.

THE DIVISION OF BOTANY.

The work of the Division of Botany is broad in scope and far reaching in results. It deals on the one hand with agricultural botany which finds expression in a study of weeds, poisonous plants. 
economic plants, shrubs and trees and, on the other, with plant pathology which concerns the diseases which attack vegetation.

In the former section the Dominion Botanist gives careful study to newly introduced weeds and others that by reason of serious prevalence or persistent habits threaten the crop production of a vicinity. Besides communicating helpful information to correspondents who send specimens, or report the presence in their crops, of special weeds, occasion is taken to warn farmers in certain districts, threatened by the invasion of weeds, which may result in serious consequences. To this end posters of warning showing specimens in natural colours are widely distributed in sections likely to be injured.

This Division co-operates with the Health of Animals Branch in identifying and suppressing plants that by reason of their poisonous properties endanger the health of farm animals. Study is given also to plants that may possess economic properties for manufacturing, medicinal or other commercial purposes.

In the work of plant pathology this Division exercises a far reaching benefit in the study of plant diseases. Study is given to diseases of cereal, fruit and vegetable crops as well as of forest trees. A constant vigilance is maintained in order to prevent the introduction of diseases new to the country. In cases of dangerous introductions these are dealt with by regulations made under the Destructive Insect and Pest Act to prevent the importation or distribution of infected vegetable matter. Besides this all reasonable means are taken to warn the public of possible danger from threatening plant maladies. Plant diseases are studied partly in the pathological laboratory and partly in the field and pathological greenhouse. Amongst the diseases at present under investigation may be mentioned silver leaf of fruit trees, scab and rhizoctonia disease of potatoes, smut diseases of grains and several others.

The spacious and richly planted botanic gardens and arboretum of the Central Farm have been placed in charge of the Dominion Botanist. Their scenic beauty and situation well serve as a centre for botanical study. Together with a well classified large herbarium of the Flora of Canada exceptional opportunities are thus placed at the disposal of the scientific student and interested public. 


\section{RECENT DEVELOPMENTS OF THE FARM SYSTEM.}

The value of the work of the Experimental Farms to the country has been deeply appreciated by the farming community both in and out of Parliament, irrespective of political allegiance. There has been no tendency on the part of the representatives of the people to ask for a curtailment of the work. On the other hand, the call has been strong for its extension.

Until recently certain provinces were served only by Farms in adjoining provinces while conditions of soil and climate in certain districts differed so widely as to require special facilities for the study of agricultural problems. By Farms or Stations every province has now been reached and in addition sub-stations have been established to serve outlying districts and sections within provinces possessing unusual conditions.

During the past four years eleven new Farms or Stations have been added to the five original Farms. These are situated at Charlottetown in Prince Edward Island; Kentville in Nova Scotia; Fredericton in New Brunswick; Cap Rouge and Ste. Anne de la Pocatière in Quebec; Rosthern and Scott in Saskatchewan; Lethbridge and Lacombe in Alberta and Invermere and Sydney in British Columbia. To these must be added sub-stations situated at Kamloops in British Columbia, Fort Vermillion on the Peace River and Forts Smith, Resolution and Providence and Athabaska Landing beyond the 6oth parallel of latitude where some experimental work is being carried on.

A further recent development of the system has been to greatly strengthen the staff of officers. The number of scientifically trained assistants in all the Divisions at the Central Farm has been materially increased in order to cope successfully with the ever increasing work.

The duties and responsibilities of the heads of certain Divisions have been increased. Mr. Frank T. Shutt, M.A., F.I.C., who has been associated with the work of the Farms since their establishment, in addition to his duties as Dominion Chemist has been made Assistant Director of Experimental Farms. Mr. W. T. Macoun has been raised to the position of Dominion Horticulturist which gives him authority over the horticultural work of all the Farms. The scope of the cereal work has been widened by the elevation of the Cerealist, Dr. Charles E. Saunders, to the position of Dominion Cerealist. The Live Stock work of the system has been put in charge of $\mathrm{Mr}$. 
E. S. Archibald, B.A., B.S.A., who is known as the Dominion Animal Husbandman.

Another advance has been the creation, in I9I2, of the Division of Agrostology under M. O. Malte, Ph.D., who for a number of years was engaged in research work at the famous plant breeding station at Svalof, Sweden. Dr. Malte will devote his time to the improvement of the quality and yield of the grasses, clovers, alfalfas, roots and other forage crops grown in Canada.

Although there has been an apiary at the Central Farm for many years it has not until recently had the supervision of a special officer. In order to give the science of bee-keeping the attention it deserves a trained apiarist in the person of Mr. F. W. L. Sladen of Dover, England, has been appointed and attached to the Division of Entomology where he will devote his whole time to investigational and educational work bearing on apiculture.

A change that may be noted is the retirement, after almost a quarter of a century of useful service, of Mr. Thos. A. Sharp, Superintendent of the Farm at Agassiz, B. C. who, is succeeded by Mr. P. H. Moore, B.S.A., a native of Nova Scotia, and a graduate of the Ontario Agricultural College. Mr. Sharp is still engaged in experimental work in horticulture at Salmon Arm, British Columbia.

Two years ago the standing of the Agriculturist at the Central Farm, Mr. J. H. Grisdale, B. Agr., was advanced to that of Dominion Agriculturist, who upon the retiring of Dr. William Saunders, was promoted to the foremost position on the staff-that of Director. The Director is also the acting Dominion Field Husbandman, the work connected therewith being under the immediate charge of his assistant Mr. O. C. White, B.S.A.

Under the Directorship of Mr. Grisdale, the Experimental Farm System will undoubtedly continue to do effective work. Himself a scientifically trained and highly experienced farmer with thirteen years of close application to the field crop and live stock work of the Central Farm and during which time he has many times visited the several provinces of the Dominion and the Branch Farms, Mr. Grisdale brings to bear on his enlarged duties a fund of knowledge, experience and energy that cannot fail to direct the work into channels that will effectively influence for good the agriculture of the Dominion.

This is the more to be expected because of the broad-minded policy of the presiding Minister, the Honourable Martin Burrell, whose sympathy with the work is shown in the well-marked expansion that has taken place since he took office. 
Valuable as has been the work of the Experimental Farms during a quarter of a century in leading the way to a better agriculture, we may confidently expect that the Farms have entered upon a period of still greater usefulness on account of the well-marked indications-Ist. the opening up of new areas to agriculture, and 2nd, the pronounced increasing desire on the part of the agricultural population to take full advantage of the lessons that the Farms in and through their work are able to teach; and finally the fuller and more adequate equipment to carry on the much needed research work concerning Canadian Agriculture.

\section{LIST OF PAST AND PRESENT DIRECTORS, CHIEF OFFICERS OF DIVISIONS AND SUP- ERINTENDENTS OF BRANCH FARMS AND STATIONS.}

DiRECTORS-

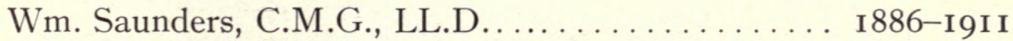

J. H. Grisdale, B. Agr.................. I9I I

Assistant Director-

Frank T. Shutt, M.A............. I9I2

Agriculturists-

(Acting) Wm. Saunders, C.M.G., LL.D......... I I887-I890

Jas. W. Robertson, L.L.D . . . . . . . . . . . . . . I 1890-I896

(Acting) Wm. Saunders, C.M.G., L.L.D. . . . . . . I I897-I898

J. H. Grisdale, B. Agr... . . . . . . . . . . . . . . I899-I9I I

(Acting) J. H. Grisdale, B. Agr.............. I9I I-I9I2

Agrostologist-

M. O. Malte, Ph. D............... I9I2

Animal Husbandman-

E. S. Archibald, B.A., B.S.A. ........... I9I2

Field Husbandman-

(Acting) J. H. Grisdale, B. Agr.............. I9I2

O. C. White, B.S.A. (Assistant)........... I9I2 $32880---6$ 
HORTICULTURISTS-

W. W. Hilborn. . . . . . . . . . . . . . . . . . $1887-\mathbf{1} 889$

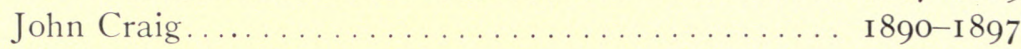

W. T. Macoun. ....................... I 1898

Cerealists-

(Acting) Wm. Saunders, C.M.G., L.L.D. . . . . . . I I887-I902

C. E. Saunders, Ph. D. (termed Experimentalist,

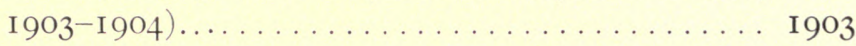

\section{Chemist-}

Frank T. Shutt, M.A., F.I.C............... I 887

A. T. Charron, M.A. (First Assistant).......... I 898

Entomologist and Botanist-

Jas. Fletcher, L.L.D . . . . . . . . . . . . . . I I887-I908

Entomologist-

C. G. Hewitt, D.Sc................... I909

Arthur Gibson (Chief Assistant)............... I899

BOTANIST-

H. T. Gussow......................... 1909

J. W. Eastham, B.Sc. (Chief Assistant).......... I9I I

Poultry Manager-

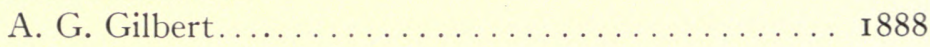

V. Fortier (Assistant).................... I903

FARM FOREMAN-

John Fixter..................... I887-1906

D. D. Gray......................... 1906

Superintendents of Branch Farms and Stations-

Experimental Station, Charlottetown, P.E.I.-

J. A. Clarke, B.S.A................... I909

Experimental Farm, Nappan, N.S.-

Wm. M. Blair...................... I887-1896

Geo. M. Forrest..................... I896-I897

R. Robertson....................... I 898

Experimental Station, Kentville, N.S.-

W. Saxby Blair.................... 1912

Experimental Station, Fredericton, N.B.-

W. W. Hubbard................... I9I2 
Experimental Station, Ste. Anne de la Pocatière, Que.-

Joseph Begin..................... I9I2

Experimental Station, Cap Rouge, Que.-

G. A. Langelier................... I9II

Experimental Farm, Brandon, Man.-

S. A. Bedford ..................... I888-I905

N. Wolverton, B.A................ I906-1907

Jas. Murray, B.S.A................ I907-I9II

W. C. McKillican, B.S.A............... I9II

Experimental Farm, Indian Head, Sask.-

Angus Mackay..................... I 1888

Experimental Station, Rosthern, Sask.-

Wm. A. Munro, B.A., B.S.A............. 1909

Experimental Station, Scott, Sask.-

R. E. Everest, B.S.A................ I9I I

Experimental Station, Lethbridge, Alta.-

W. H. Fairfield, M.S.................. 1906

Experimental Station, Lacombe, Alta.-

G. H. Hutton, B.S.A................. 1907

Experimental Farm, Agassiz, B.C.-

Thos. Sharpe..................... I888-I9II

P. H. Moore, B.S.A................... I9II

Experimental Station, Sydney, B.C.-

Samuel Spencer..................... I9I2 


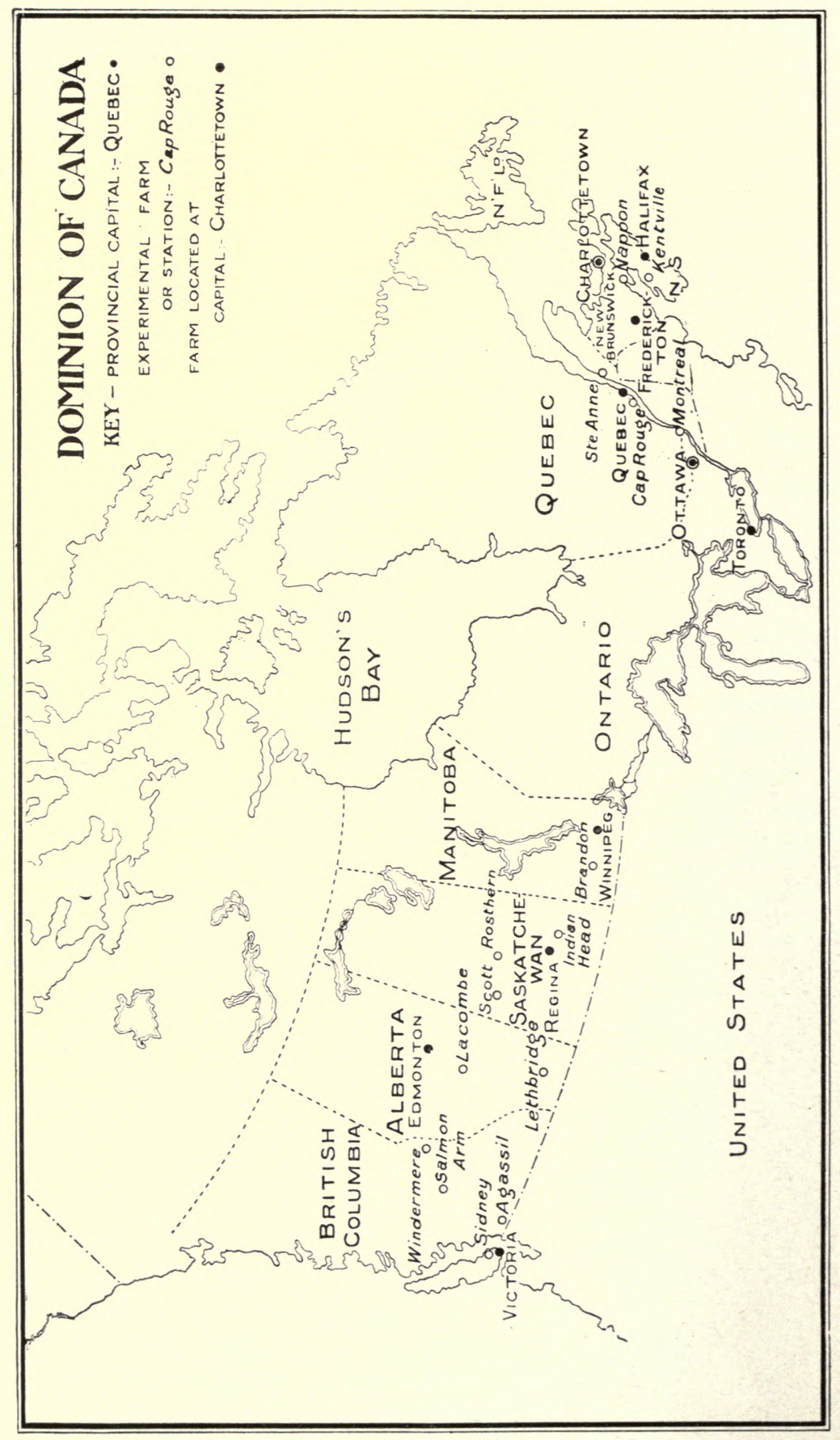




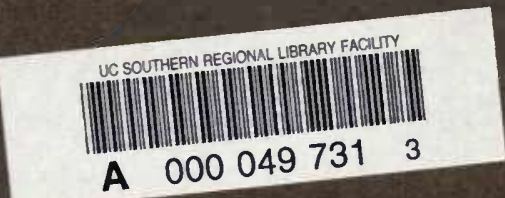




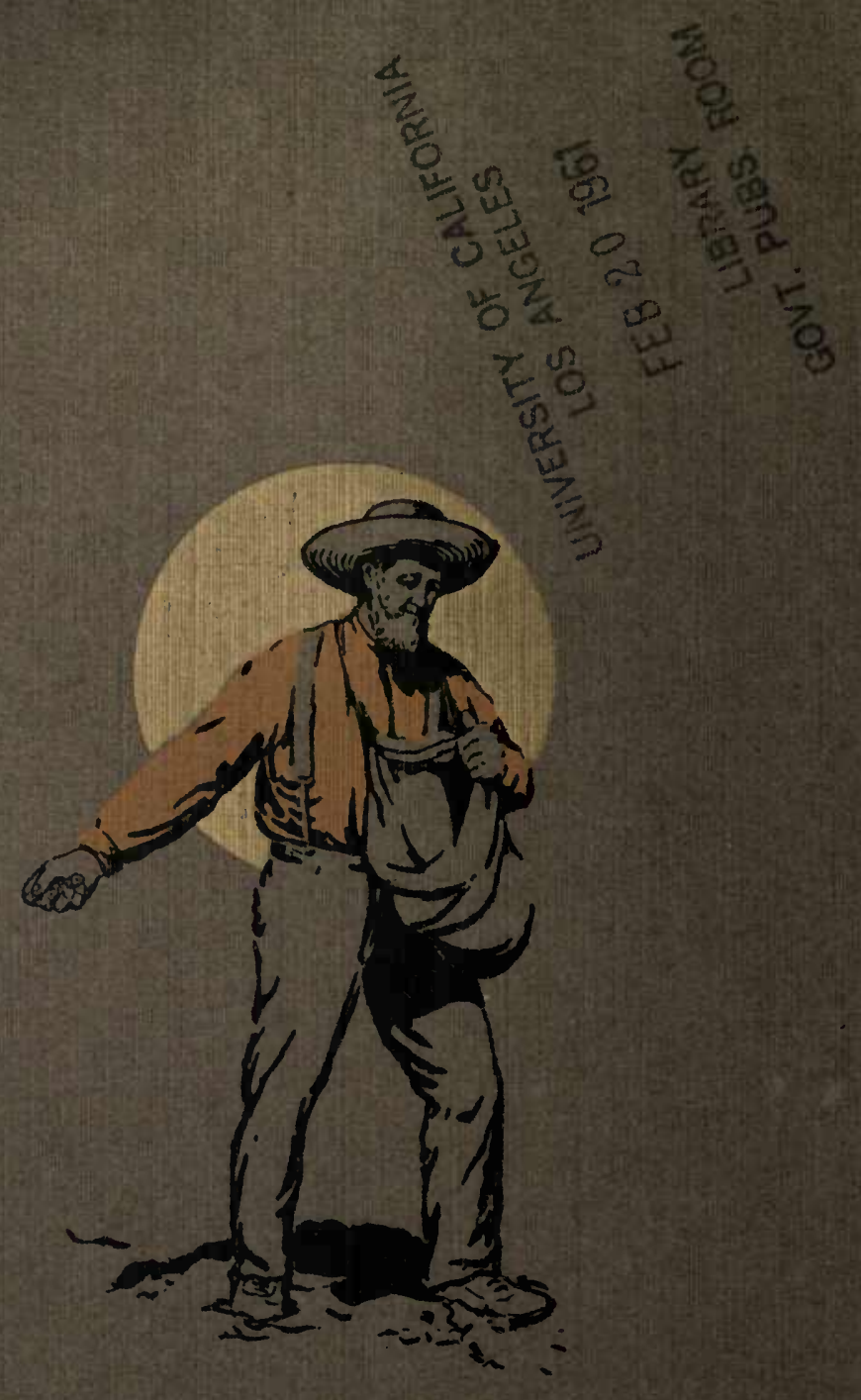

D

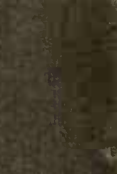

